\title{
16. CALCAREOUS NANNOFOSSIL BIOSTRATIGRAPHY OF A LOWER CRETACEOUS DEEP-SEA FAN COMPLEX: DEEP SEA DRILLING PROJECT LEG 93 SITE 603, LOWER CONTINENTAL RISE OFF CAPE HATTERAS ${ }^{1}$
}

\author{
J. Mitchener Covington and Sherwood W. Wise, Jr., Department of Geology, Florida State University ${ }^{2}$
}

\begin{abstract}
Upper Berriasian to lower Aptian calcareous nannofossil assemblages have been studied from a siliciclastic deep-sea fan complex and a subjacent limestone sequence drilled beneath the lower continental rise in the western North American Basin, 270 miles (435 km) off Cape Hatteras, North Carolina (USA). Sharp lithologic facies changes and reworking by turbidites complicate the biostratigraphic interpretation, but provide an excellent opportunity to better distinguish "nearshore" from open-ocean nannofossil species, and to investigate the introduction of neritic taxa into the deep-sea environment, a phenomenon that appears to have been widespread within the circum-North Atlantic during Neocomian times. Well-preserved assemblages in dark, carbonaceous claystones were probably displaced from the oxygen minimum zone along the upper slope or outer shelf. Neritic, continental margin species prevalent in this facies include the holococcolith Zebrashapka vanhintei n. gen., n. sp., Lithraphidites alatus magnus n. spp., Pickelhaube furtiva n. gen., and a host of nannoconids and micrantholiths.

A qualitative evaluation of widely used guide fossils suggests that the triad of proposed markers for the base of Roth's Zone NC3 make their first appearances in the following (ascending) order: Diadorhombus rectus, Tubodiscus verenae, Calcicalathina oblongata. Of these, we chose the nominative species for the zone, $T$. verenae, to mark its base and to approximate the Berriasian/Valangian boundary. Cyclagelosphaera deflandrei is strongly affected by diagenesis and is therefore not a reliable index species for the base of Zone NC4 near the Valanginian/Hauterivian boundary (the last occurrence of $T$. verenae is also not suitable there). In addition, Lithraphidites bollii, a form apparently confined to the low latitudes of the Tethyan region, was absent at the more temperate Site 603 and not available as a subzonal marker for the upper Hautervian-lower Barremian (mid-NC4 and mid-NC5, respectively). Cruciellipsis cuvillieri, however, provides a reliable datum just below the Hauterivian/Barremian boundary (base of NC5), despite the potential for reworking in this section. Nannoconids tend to be reworked in this section, and do not provide trustworthy forms to mark the Barremian/Aptian boundary (base of NC6). Hayesites irregularis n. comb. probably does provide a useful first appearance datum within the lower Aptian, if it is not confused with a more birefringent and globular form, Rucinolithus terebrodentarius $\mathrm{n}$. sp. Rhagodiscus angustus is mimicked by a similar form (Zeughrabdotus? pseudoangustus $\mathrm{n} . \mathrm{sp}$.), which apparently ranges down to the Hauterivian, thus Lithastrinus floralis provides a more useful first appearance datum for the base of the middle-upper Aptian Rhagodiscus angustus Zone (NC7).

Aside from the new taxa mentioned above, the following are also described: Cretarhabdus? delicatus $\mathrm{n}$. sp. and $C y$ clagelosphaera jiangii $\mathrm{n}$. sp.
\end{abstract}

\section{INTRODUCTION}

During the past decade and a half of deep-sea drilling in mostly open ocean environments, calcareous nannofossils have been thrust to the forefront as premier guide fossils for accurate and rapid age dating of calcareous pelagic sediments, particularly where other microfossil groups are poorly represented because of exclusion from the sediments by preservational or paleoenvironmental factors (Bukry, 1981). "Standard," number-coded coccolith zonations have been compiled for both the Cenozoic (Martini, 1971; Okada and Bukry, 1980) and Cretaceous (Roth, 1978), and these work particularly well in the lower latitudes. In those regions, surfacewater habitats for phytoplankton are highly equitable and uniform, thereby allowing dispersion of key taxa an a "worldwide" scale, to the point that their evolutionary first appearance and extinction datums come to represent for all practical purposes global time-synchronous events.

\footnotetext{
1 van Hinte, J. E., Wise, S. W., Jr., et al., Init. Repts. DSDP, 93: Washington (U.S Govt, Printing Office)

Addresses: (Covington, present address), Texaco, Inc., P. O. Box 60252, New Orleans, LA 70160; (Wise) Dept. of Geology, Florida State University, Tallahassee, FL 32306.
}

By the second DSDP drilling leg, however, it was evident that preservational and paleoenvironmental factors can also strongly affect the composition of fossil coccolith assemblages, and also that assemblages from deepsea sediments were generally less diverse than those of the nearshore continental margins (Bukry, 1970). Nearshore "provincialism" among coccoliths has been noted in both Cenozoic (Bybell and Gartner, 1972) and Mesozoic (Roth, 1983) sequences. Up to now, however, such "provincialism" has not adversely affected the utility of the more recent number-coded zonations, because efforts have been made to exclude from these schemes "nearshore" marker species or to include them only as alternate, subzonal datums (e.g., Okada and Bukry, 1980; see discussion by Gartner, 1977).

Thus outside of the high latitudes the commonly used number-coded coccolith zonations have worked remarkably well for open-ocean DSDP sections. During the later years of the International Program for Ocean Drilling (IPOD), however, strong sentiment developed within the scientific community to attempt more drilling along the continental margins. DSDP Leg 93 to the North American Basin was dedicated to this purpose and succeeded in recovering at reentry Site 603 on the lower continental 
rise (Fig. 1) an extensive Lower Cretaceous section that contained an appreciable input of nearshore sediments redeposited as turbidites. The resulting lithologic sequence is complicated compared to those of more open marine environments, and accordingly, the interpretation of the coccolith content of these sediments is not as straightforward. As will be pointed out below, this inter- esting circumstance is not unique to Site 603 , but appears to be a phenomenon of the North Atlantic-Tethyan continental margins that will be encountered with increasing frequency as drilling of those margins proceeds. For that reason, an understanding of the types of coccoliths represented in these sequences, their relationship to the varied and rapidly alternating lithologies, their

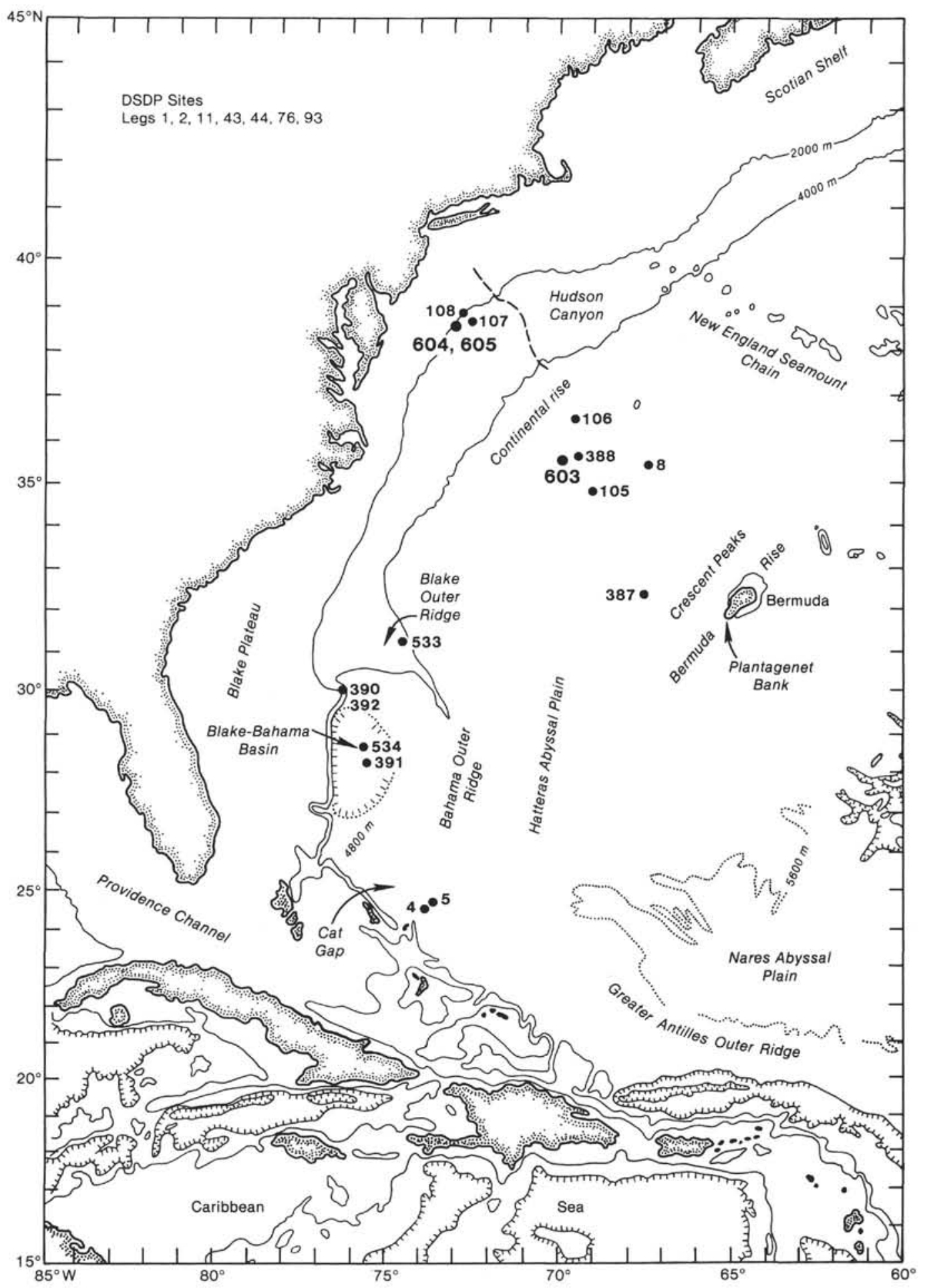

Figure 1. Location of DSDP Site 603 and neighboring sites in the North American Basin. 
mode of deposition in relation to the development of deep-sea fan complexes, and their biostratigraphic utility in these paleoenvironments is essential before coccolith zonations can be applied as readily in these circumstances and with equal facility as those developed for the more open-margin environments traditionally drilled by DSDP.

We present here a reconnaissance study of the Cretaceous nannofloras recovered at Site 603. Our emphasis in this Initial Report chapter has been placed on documenting the assemblages by scanning electron microscopy in order to complement the recent light microscopy studies carried out in the North American Basin by Roth $(1978,1983)$. We have also sought to distinguish "nearshore" (in many cases dissolution-susceptible) species from the more ubiquitous open-ocean varieties as a first step toward evaluating their biostratigraphic utility. Eventually, with more detailed study of this section, we hope to develop a more refined zonal scheme applicable to these paleoenvironments. In the interim, we are applying the number-coded scheme compiled by Roth $(1978,1983)$ for this region. In the future, we also wish to study additional Lower Cretaceous sequences around the circumNorth Atlantic in order to better relate variations in nannofossil assemblages to the various lithologies of deepsea fan complexes.

\section{LITHOSTRATIGRAPHY}

Reentry Hole $603 \mathrm{~B}\left(35^{\circ} 29.71^{\prime} \mathrm{N}, 70^{\circ} 01.71^{\prime} \mathrm{W}\right)$, deepest at Site 603, was drilled in $4642.5 \mathrm{~m}$ of water on the lower continental rise 270 miles $(435 \mathrm{~km})$ east of Cape Hatteras, North Carolina (Fig. 1), and terminated at $1585.2 \mathrm{~m}$ sub-bottom in upper Berriasian limestones due to failure of the drill string. Units penetrated by this and other holes at the site are depicted in Figure 2. Figure 3 provides a detailed view of the major lithologic components in the Cretaceous section. Despite facies differences caused by the influx of terrigenous sediments from the nearby continent, general correlations can be made between our local lithologic units and the oceanic formations proposed for the North American Basin by Jansa et al. (1979). It should be noted from the outset that because the carbonate compensation depth $(\mathrm{CCD})$ in the Basin resided above our site of deposition from Aptian to mid-Miocene times (as predicted by Tucholke and Vogt, 1979, fig. 3), lithostratigraphic Subunit IC through Unit IV are essentially devoid of calcareous nannofossils. In descending order, the units that contained Mesozoic nannofossils and their correlations are as follows.

Unit IV-106 m of mid-Cretaceous (Aptian-Turonian) black carbonaceous claystones (Hatteras Formation). The first Cretaceous coccoliths encountered during drilling at this site were in two thin (5- to 10 -mm thick) nannoconites from Core 603B-35. These limestone layers, which contain only Nannoconus, exhibit gradational contacts and have not been redeposited from shallower depths. They represent enhanced production of these nannoplankton in quantities sufficient to depress the CCD temporarily below the site of deposition, thereby enabling their accumulation. Otherwise, this formation was barren of coccoliths.
Unit V-261 $m$ of upper Berriasian-Aptian interbedded nannofossil clays and limestones with sandstone to claystone turbidites (Blake-Bahama Formation plus an unnamed sand unit at the top of the sequence). This unit is distinguished from the overlying lithostratigraphic Unit IV by the presence of abundant calcareous nannofossils. It is subdivided into two subunits based on the presence or absence of turbidites. Subunit VA includes $30 \mathrm{~m}$ of largely unconsolidated sand at the top and is further characterized by abundant claystone, siltstone, and sandstone turbidites and debris flows (Fig. 4). These are of two main types: siltstone-sandstone and organic-matter-rich claystone. The presence of intermediate types in addition to complete sandstone to claystone graded sequences indicates that the two textural types are related. The turbidite sequence constitutes approximately $298 \mathrm{~m}$ of section and, over a $218-\mathrm{m}$ interval, consists of $47 \%$ sand.

The silt and sandstone turbidites first appear in the Hauterivian (Core 603B-73), reach a peak in the Barremian (Core 603B-56), then culminate with the emplacement of a rather massive, poorly consolidated sequence that spans the Barremian-Aptian boundary (Cores 603B48 to -46 ). Coarse, loose sands with shallow-water shell fragments (disturbed by drilling) constitute nearly all of the sediment recovered from Cores 603B-45 and -46 . Below Core 48 , individual turbidites range up to $2 \mathrm{~m}$ in thickness and are dominated by subangular quartz with abundant feldspar, mica, heavy minerals, opaques, wood fragments (locally up to $20 \%$ ), glauconite, and shallowwater bioclastics. Collectively, these turbidites exhibit the entire range of Bouma structures; however, the basal sequences $\left(\mathrm{T}_{\mathrm{a}}\right.$ to $\mathrm{T}_{\mathrm{c}}$ ) are dominant (Sarti and von Rad, this volume).

Apparently Hole 603B intersected a complex of one or more deep-sea fans that perhaps form part of an apron of clastic-rich sediments of this age along the lower continental margin of eastern North American (Leg 93 staff, 1983). Their deposition was coincident with the construction of major deltas along the eastern seaboard of the present United States. Coeval coarse terrigeneous turbidites have also been encountered at DSDP Sites 391 and 534 to the south (Sheridan, Gradstein, et al., 1983) and are by no means confined to the western North Atlantic. A similar phenomenon has been recorded in the southern Wessex Basin of England (Wealden Beds), and deepsea fans of this age have been cored off northwest Africa at DSDP Sites 370 and 416 (Lancelot, Winterer, et al., 1980). See Hallam $(1984,1986)$ for a review of the occurrence of this "Wealden-type facies" throughout the Tethyan-mideastern realm.

Subunit VB is composed exclusively of in situ pelagic carbonates that consist of rhythmic alternations of laminated and bioturbated nannofossil chalks and limestones. These lithologies also occur in Unit VA (Figs. 3 and 4).

\section{PREVIOUS LOWER CRETACEOUS NANNOFOSSIL STUDIES IN THE NORTH AMERICAN BASIN}

Lower Cretaceous coccolith-rich strata were interval cored during the inaugural DSDP Leg 1 at two closely 


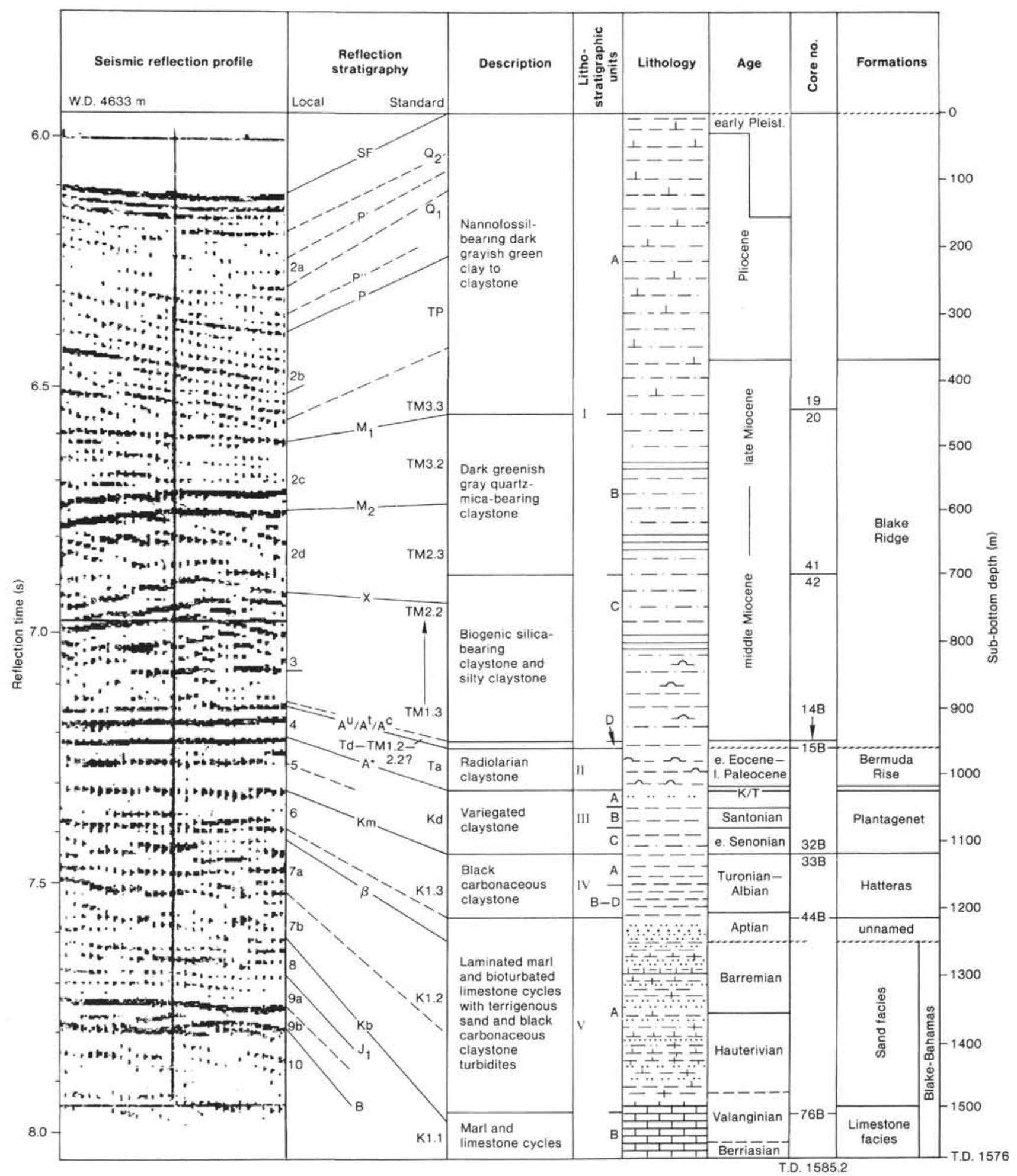

Figure 2. Stratigraphic summary of Site 603 (Holes 603, 603B, and 603C). Units I-V are local lithostratigraphic units (from Site 603 chapter, this volume).

spaced localities, Sites 4 and 5 east of the Bahamas. Initially described by Bukry and Bramlette (1969) and Hay (1969), the coccolith assemblages in these sequences were investigated in more detail by Worsley (1971), who described many new species, and by Thierstein (1971), who proposed a set of tentative zones and datums on which most subsequent Lower Cretaceous zonations (Thierstein, 1973; Roth, 1978, 1983) have been based. Because of the difficulty of correlating spot cores among the three holes that penetrated the Lower Cretaceous at Sites 4 and 5, some difficulties of opinion remain as to the exact stratigraphic placement and sequence of some of the 

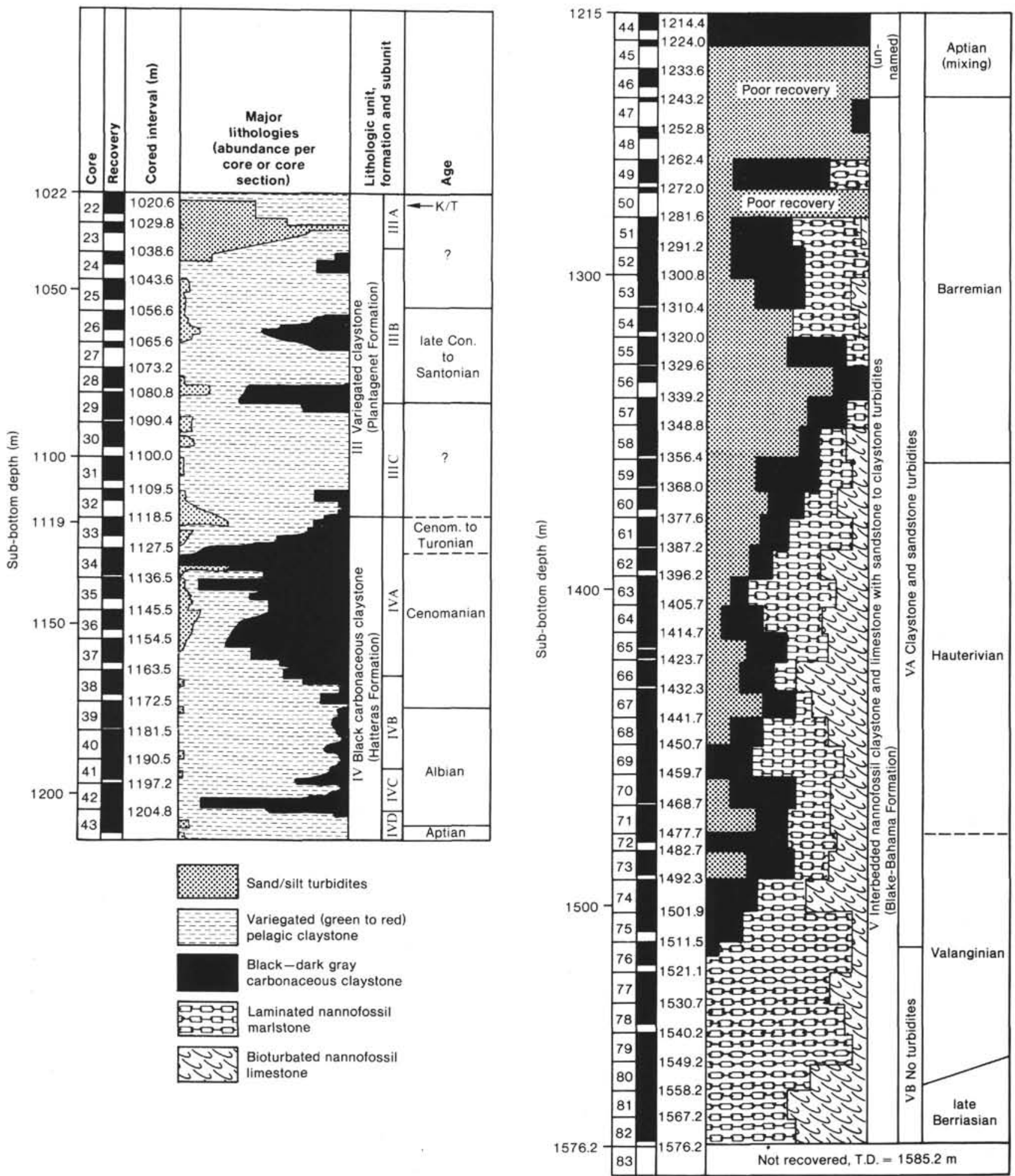

Figure 3. Columnar section of the Cretaceous interval of Hole 603B.

original Leg 1 samples (compare Worsley, 1971; Thierstein, 1971; and Barnard and Hay, 1971).

Lower Cretaceous sediments were next recovered at DSDP Leg 11 Sites 99 to 101 off the Bahamas and Site 105 at the northern end of the Hatteras Abyssal Plain. The nannofossil assemblages recovered were initially described by Wilcoxon (1972), and subsequently in more detail for the Berriasian and Valanginian by Thierstein (1975).

A Neocomian nannofloral succession quite similar to that at Site 105 was described by Okada and Thierstein (1979) from a long (200-m) interval cored with poor recovery at DSDP Leg 43 Site 387 on the Western Bermuda Rise. Nearly continuous coring over a 300-m section 


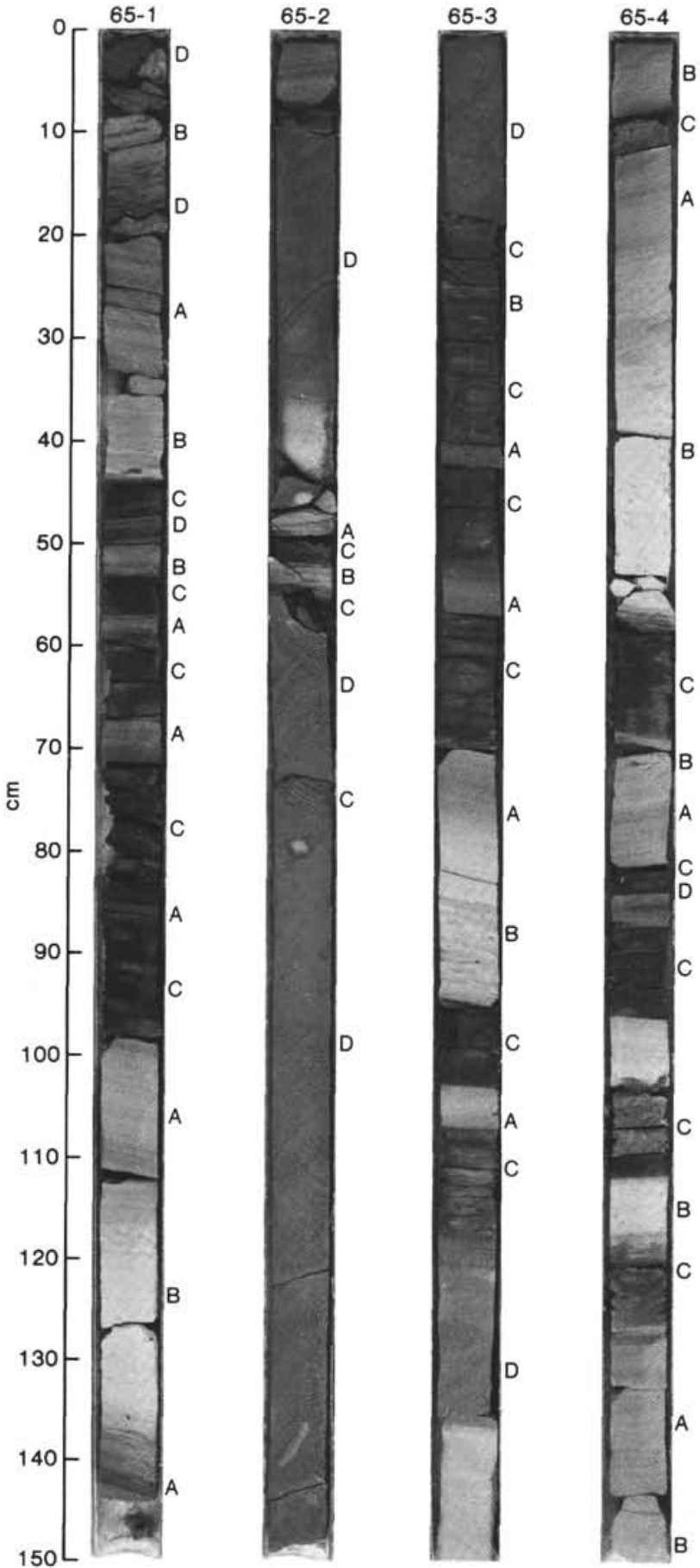

Figure 4. Core 603B-65 from lithostratigraphic Unit VA (Blake-Bahama Formation, Valanginian-Aptian). Gray laminated marlstone (A) and white bioturbated limestone cycles (B) interrupted by black carbonaceous claystone turbidites $(\mathrm{C})$ and terrigenous sandstone turbidites (D). The sandstone bed spanning Sections 65-2 and 65-3 is $90 \mathrm{~cm}$ thick.

at Leg 44 Hole $391 \mathrm{C}$ in the Blake-Bahama Basin provided a Lower Cretaceous reference section for Roth's (1978) number-coded zonation and his attendant set of oceanic stages defined by those zones. This locality was subsequently redrilled only $22 \mathrm{~km}$ away at Leg 76 Hole 534A, where continuous coring through more than $600 \mathrm{~m}$ of carbonate-rich Lower Cretaceous sediment provided Roth (1983) with additional material to refine his zonal scheme. During the interim, DSDP Legs 51 to 53 cored short but important Albian-Aptian sections with generally poor recovery at DSDP Holes 417D and 418A near the southern end of the Bermuda Rise. In particular, these holes provided some well preserved early Aptian nannofossil assemblages with high abundance and diversity.

\section{METHODS, ZONATIONS, AND SPECIES CONSIDERED}

The nannofossil assemblages were described from smear slides made directly from the sediment sample and examined at a magnification of $1000 \times$. Estimates of the abundances of individual nannofossil species on the smear slides were tabulated on the range chart using the method of Hay (1970). Letters used to denote abundances are keyed to the $\log _{10}$ of the number of species of a taxon likely to be observed in any one field of view of the microscope. These and the corresponding logs are determined as follows:

$\mathrm{V}=$ very abundant, +1 (more than 10 specimens per field of view)

$\mathrm{A}=$ abundant, 0 (1-10 specimens per field of view)

$\mathrm{C}=$ common, -1 ( 1 specimen per 2-10 fields of view)

$F=$ few, $-2(1$ specimen per $11-100$ fields of view $)$

$R=$ rare, -3 (1 specimen per 101-1000 fields of view)

Selected samples were studied by scanning electron microscopy using procedures outlined by Wise and Kelts (1972).

As noted previously, the zonal compilation used as a guide in this study (Fig. 5) is that of Roth (1978) as updated by Roth (1983) for Site 534 , which lies some $820 \mathrm{~km}$ southwest of our locality. We used Roth's zonation because it is the most recent to be applied to the Lower Cretaceous of the North American Basin, and we wish to facilitate correlation with his extended section at Site 534 .

In revising his zonation for Site 534, Roth (1983) made a number of significant modifications in the Lower Cretaceous. Comparing his summary charts (Roth, 1978, fig. 2, and Roth, 1983, fig. 6) and beginning at the bottom (our Fig. 5), one finds that the FAD of Cruciellipsis cuvillieri s. str. has been lowered from the upper Berriasian (lower $\mathrm{NC2}$ ) to the basal Berriasian (mid-NC1). The co-occurrence of the FAD of Speetonia colligata with that of C. cuvillieri s. str. on the 1983 chart conflicts with the accompanying text and range chart that would place this event not far below the mid-point of NC2.

In discussing the datums for the top of NC3, Roth noted (1983, p. 612) that Diadorhombus rectus, the co-marker for his original Turbodiscus verenae- $D$. rectus Zone, "appears to range longer than was originally thought (Thierstein, 1976; Roth, 1978). It does appear to range into the Hauterivian or even the basal Barremian." Further noting that its occurrence is spotty, he deleted it as a zonal name and comarker for the top of NC3, relying instead, according to his text, on the LAD of $T$. verenae. He remarks, however, that the occurrence of this species is somewhat discontinuous in its upper range at Site 534, and that a narrow taxonomic concept must be maintained if its extinction is to serve as a reliable marker. The LAD of the species does not appear on the summary chart (Roth, 1983, fig. 6) but is replaced there by the LAD of Cyclagelosphaera deflandrei (Fig. 5). No mention or further explanation of this latter datum is given in the text, but Thierstein (1976, fig. 7) does plot the LAD of T. verenae at the top of the Valanginian (which is equivalent to the top of NC3).

The next modification involves the use of Lithraphidites bollii (Thierstein) as a zonal marker. Thierstein (1971) originally used this species to mark the base of his $L$. bollii Zone, which he traced from southeastern France to the equatorial Atlantic (DSDP Site 4). Roth (1978) used both the FAD and the LAD of $L$. bollii as subzonal datums in the mid-Hauterivian and mid-Barremian to subdivide Zones NC4 and NC5, respectively. Roth (1983, p. 602), however, relates that "Although looked for, Lithraphidites bollii was not found at Site 534 nor at Site 391. I suspect $L$. bollii might be an artificial fossil, that is, either a stem fragment of a heavily overgrown specimen of Rhabdolekiskus parallelus." Accordingly, he deleted the $L$. bollii datums from is 1983 chart along with the attendant subzones, and in their stead, inserted a variety of other datums. As will be pointed out below, at Site 603 we also did not observe $L$. bollii.

One of the alternate datums Roth (1983) suggests for the mid-Barremian (mid-NC5) is the FAD of Rucinolithus irregularis, which he 


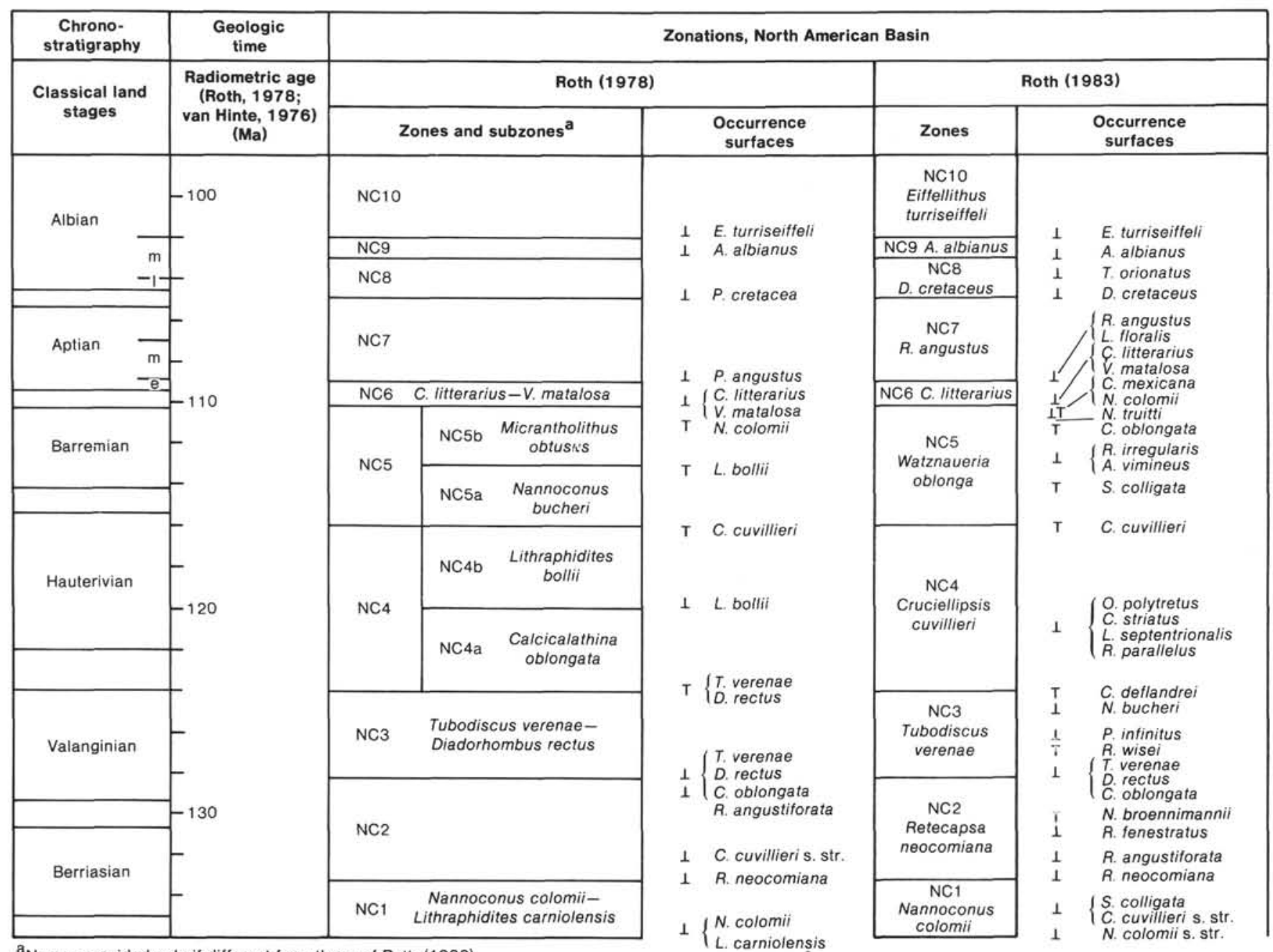

\footnotetext{
${ }^{a}$ Names provided only if different from those of Roth (1983).
}

Figure 5. Zonal compilation used as a guide in this report (from Roth, 1983) compared with a previous compilation for the North American Basin (from Roth, 1978). FAD (first appearance datum) indicated by $\perp$; LAD (last appearance datum), by T.

notes was not recorded below the Aptian by Thierstein (1976) or PerchNielsen (1979). The exact placement of this datum is of some importance in that it has previously been suggested as an alternate marker for approximating the Barremian/Aptian boundary (Thierstein, 1973).

Taxa considered in this report are listed in Appendixes A and B, where they are arranged alphabetically by generic and specific epithets, respectively. Bibliographic references for these species are given in the "Annotated Index and Bibliography of the Calcareous Nannoplankton" by Loeblich and Tappan (1966-1973) and the "Bibliography and Taxa of Calcareous Nannoplankton" by van Heck (1979-1983) and Steinmetz (1984a,b-1985).

\section{HOLE SUMMARY}

\section{Biostratigraphy}

From the outset, we call attention to two potential problems that must be kept in mind when dealing with the nannofossil assemblages from Hole 603B. The first is the possibility of downhole contamination due to sands caving from the loose, massive sand unit encountered from Cores 603B-45 to -46 (the unnamed unit at the top of lithologic Unit VA). Loose sands similar to those in Cores 45 and 46 filled the top of the core liner of Core 72 following a bit change, an indication that hole condi- tions were never fully stabilized even when drilling had reached that level. The second potential problem is reworking, particularly the displacement by turbidites of older nannofossils into younger units. Because the lithologies become increasingly complex from the bottom of the hole upwards and the possibilities of uphole and downhole contamination increase concurrently, we will describe the nannofossil assemblages in ascending order beginning with Core 603B-82. Because of the complexities at the top of the section and our desire pinpoint the time at which massive sands at the top of Unit V were emplaced, our sample spacing in Core 44 is far closer than in any other core (see Table 1).

In general, coccolith preservation is poorest in the carbonate-rich limestones and chalks and best in the black carbonaceous claystones. This is probably caused by two factors. One, the dissolution-diffusion-reprecipitation reactions that convert nannofossils to limestone work most efficiently in carbonate-rich sediments where clays and other silicates are not present in sufficient quantities to inhibit the process (Schlanger and Douglas, 1974; Wise, 1977). These reactions would be even more accelerated 
Table 1. Distribution of Lower Cretaceous calcareous nannofossils, DSDP Hole 603B.

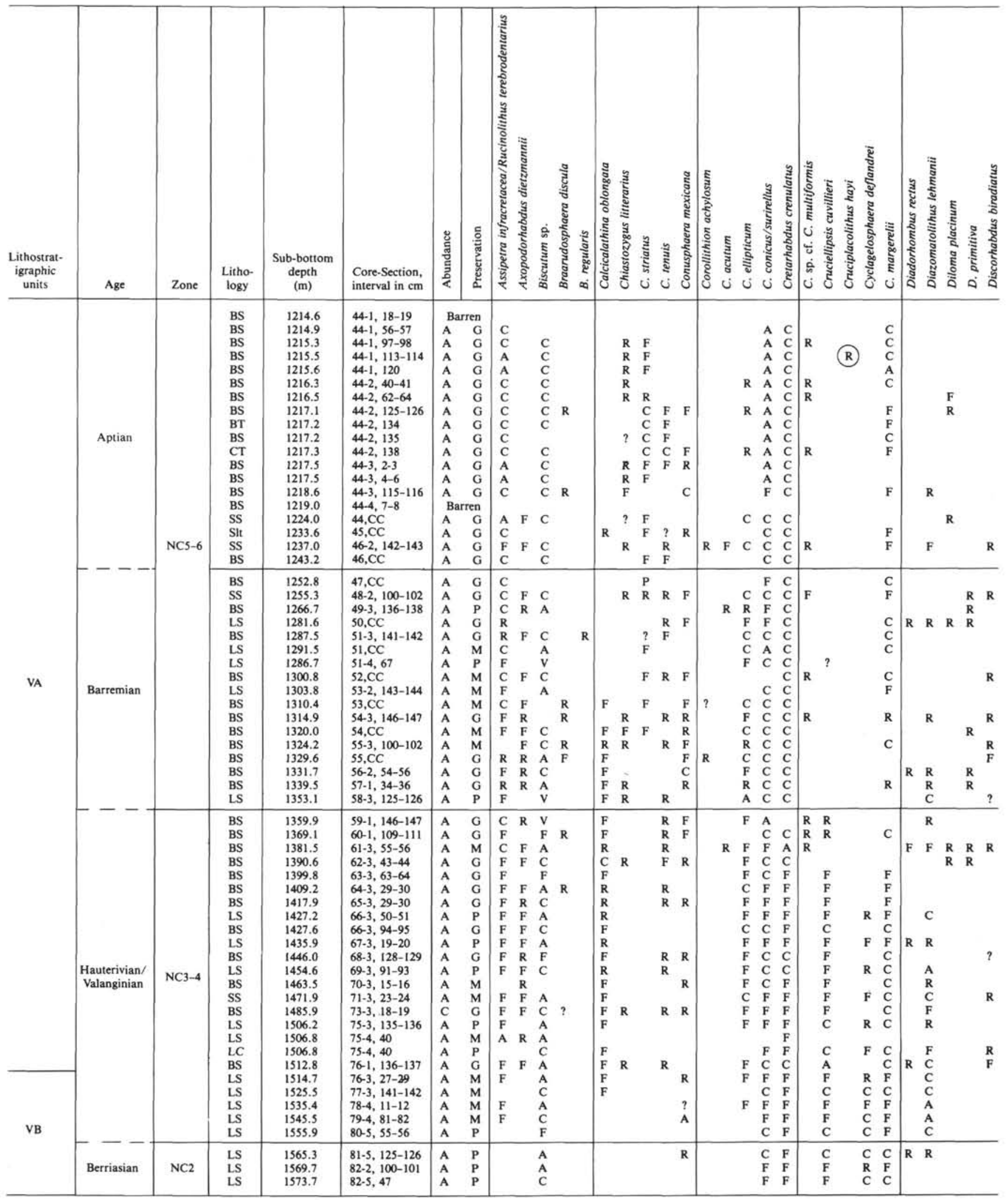

Note: $\mathrm{BS}=$ black shale, $\mathrm{BT}=$ brown turbidite, $\mathrm{CT}=$ chocolate turbidite, $\mathrm{LC}=$ laminated chalk, $\mathrm{LS}=$ limestone, $\mathrm{SS}=$ sandstone, $\mathrm{Slt}=$ siltstone. $\mathrm{V}=$ very abundant, $\mathrm{A}=$ abundant, $\mathrm{C}=$ common, $R=$ rare. $(R=$ SEM only, $G=$ good, $M=$ moderate, $P=$ poor. 


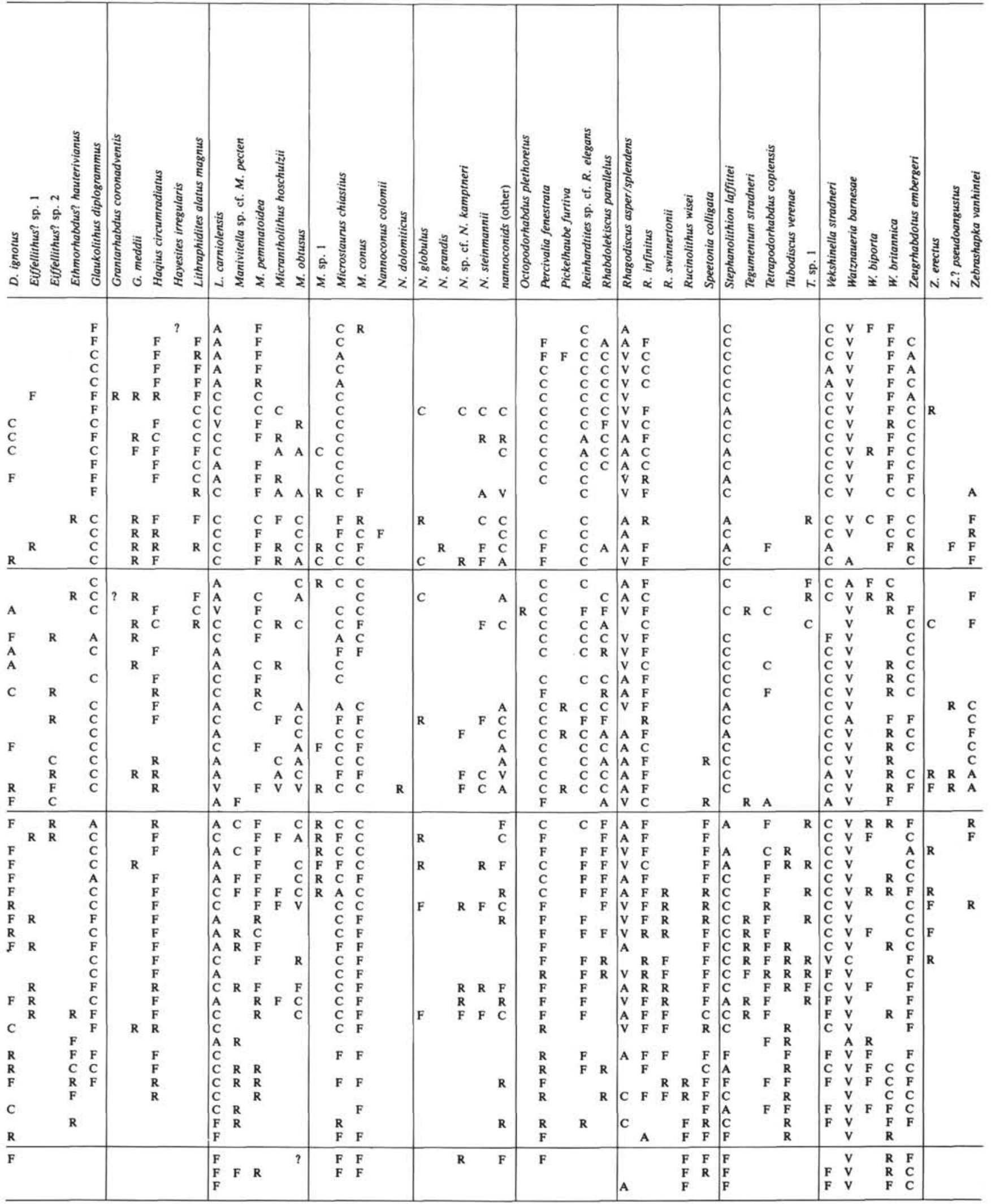


where the sediments are strongly bioturbated. Second, the black carbonaceous claystones at this site are thought to have been redeposited as mud turbidites. Their contained coccoliths, therefore, may have originally been deposited at much shallower depths (such as within the oxygen minimum zone on the upper slope)-well above the CCD where dissolution would have been less intense. If this was so, however, it raises even more pointedly the question of possible reworking of older coccoliths in this particular lithology.

Preservation of coccoliths in Cores 603B-82 to -80 , where bioturbated limestones are particularly common (Fig. 4), is poor, as indicated by the quality of the specimens shown in Plate 15, Figures 8 and 9 (compare with the same taxon in Plate 15, Fig. 7) and in Plate 17, Figure 4 . The assemblage of Core 82 , like essentially all others in this section, is dominated by Watznaueria barnesae (accompanied by several related species) and, to a lesser extent, the Rhagodiscus asper/splendens plexus, neither of which need to be mentioned in this discussion again. The rest of the preservation-limited assemblage includes few to common Cruviellipsis cucillieri, Cyclagelosphaera deflandrei, Cretarhabdus crenulatus, C. conicus/surirellus, Lithraphidites carniolensis, Manivitella pemmatoidea, Zeugrhabdotus embergeri, Tegumentum stradneri, Vekshinella stradneri, and Rucinolithus wisei. Based on the absence of the triad Diadorhombus rectus, Tubodiscus verenae, and Calcicalathina oblongata, if not due to the poor preservation, Core 82 can be assigned to Zone NC2 (lower Berriasian to lowermost Valanginian). Habib and Drugg (this volume) assign it (along with Cores 603B-81 and -80) to the Berriasian, an assignment we can neither confirm nor deny for Core 82 because NC2 just spans the Berriasian/Valanginian stage boundary.

The FAD's of the triad of basal NC3 markers mentioned above, $D$. rectus, $T$. verenae, and $C$. oblongata, were logged in Sections 603B-81-5, 603B-80-5, and 603B$77-3$, respectively. The occurrences of $D$. rectus are characteristically spotty, but those of $T$. verenae and $C$. oblongata, while few to rare, are consistent in their lower ranges. The base of Zone NC3, then, should be no higher than Section 603B-80-5 if, as is done here, the nominative zonal marker, $T$. verenae, is used. Roth (1983) suggests that $C$. oblongata is more susceptible to dissolution and ecologic restriction than $T$. verenae, which could possibly explain its higher FAD in this section, provided that Roth's dissolution ranking is correct. It seems unlikely, however, that such a robust form would be dissolution susceptible.

A curious occurrence is the FAD and unusual abundance of Rhagodiscus infinitus $\mathrm{n}$. comb. in Section 603B$80-5$. Roth (1983) placed this datum just above the LAD of Rucinolithus wisei near the midpoint of NC3, but at Site 603 , the ranges of these two taxa clearly overlap. ${ }^{3}$

Black shale turbidites (presumably redeposited) and terrigenous turbiditic sands are first encountered upsec-

\footnotetext{
${ }^{3}$ The range of $R$. wisei is apparently misplotted in Roth (1978, fig. 6) where it runs from mid-MC2 to top of NC4.
}

tion in Cores 603B-76 and -73, respectively. Upon examination of the palynomorph assemblages, Habib and Drugg (this volume) place the Valanginian/Hauterivian boundary between Cores 72 and 71 . As discussed previously, the expected nannofossil datums for this boundary would be the LAD's of $T$. verenae and/or Cyclagelosphaera deflandrei. As noted by Roth (1983) for Site 534 , the last occurrences of $T$. verenae are rather sporadic in our section. Specimens are few to rare but consistently present up to Core 603B-75, rare in the black shales and limestones of Cores 70 to 67 , and, after another absence, are rare in the black shales of Cores 62 and 61. Our data at present are too few and scattered to allow a meaningful age determination to be made on the LAD of this species, particularly because the palynomorph data would indicate that its last occurrence(s) in this section could well be reworked.

The occurrence of Cyclagelosphaera deflandrei, on the other hand, appears at first glance to be a little more consistent in its upper range where it is present in every other core. This occurrence pattern, however, denotes a second complication with this marker. The species has generally been recognized by its large size and high-order birefringence, particularly in the central area (Roth, 1973). We note from its occurrence pattern in this section of interbedded shales and limestones, however, that highly birefringent specimens tend to occur only in the carbonate-rich samples where overgrowth is most likely. It disappears completely wherever the section changes to shale (compare its occurrence with lithology in Cores 75 through 66 [Table 1]). Its LAD recorded here, therefore, is quite possibly a function (or an artifact) of preservation. We plot that LAD in $603 \mathrm{~B}-66-3,44 \mathrm{~cm}$ above a black shale where it is absent. As it is also absent in all other the black shales in the section, one cannot avoid the problem by establishing its last appearance in the black shale lithology as its true LAD.

In support of the argument just outlined, we note that the occurrences of Cyclagelosphaera deflandrei and the rather similar Haqius circumradiatus are nearly mutually exclusive, with the latter more prevalent in the shaley and clastic portions of the section (extending into the Aptian). Where their ranges overlap, $C$. deflandrei is confined to the limestone samples. It is possible that in this part of the section, overgrown $H$. circumradiatus exhibit the same high birefringence that is said to characterize C. deflandrei, and that there is no reliable way to distinguish between the two spaces, if indeed such a distinction can be made at all. The end result is that $C$. deflandrei is not a suitable marker in this particular section.

Because of the problems we have encountered with the traditional markers for the $\mathrm{NC} 3 / \mathrm{NC} 4$ zonal boundary in Hole 603B, until we are able to study more samples in this part of the section, we combine these zones and accept the designation of the Valanginian/Hauterivian boundary based on palynomorphs (Habib and Drugg, this volume). We hope that the study of additional samples will resolve this problem with the nannofossils.

The zonal boundary at the top of the combined Zones $\mathrm{NC} 3 / \mathrm{NC} 4$ is placed between Cores 58 and 59 based on 
the LAD of Cruciellipsis cuvillieri, which is used here to approximate the Hauterivian/Barremian boundary. This datum is not ideal in this section in that the abundance of the species diminishes in the upper part of its range. Its last consistent occurrence is in Core 63, and its abundance is rare in the black shales of Cores 60 and 59. An argument could be made that it is reworked in these last two cores. Our rough approximation of the Hauterivian/Barremian boundary, then, may be reasonable, because the LAD of $C$. cuvillieri actually should occur somewhat below this boundary (Thierstein, 1976).

The nannofossil and palynomorph age determinations are in closer agreement for the Hauterivian/Barremian boundary than for the Valanginian/Hauterivian boundary discussed above. Habib and Drugg (this volume) place the Hauterivian/Barremian boundary within the interval spanned by Sections 603B-57-6 and 603B-56-3. The nannoflora is quite diverse at this point, with most of the species mentioned previously still present, and with the addition of: rare Chiastozygus tenuis and forms that we find virtually indistinguishable from $C$. litterarius starting in Core 62; sporadic Conusphaera mexicana (which was most abundant in Sample 603B-79-43, 81-82 cm); few to abundant Assipetra infracretacea/Rucinolithus terebrodentarius n. sp., Glaukolithus diplogrammus, and Corollithion ellipticum; a rare occurrence of C. acutum in Core 61; rare Diloma placinum and related forms first encountered in the black shales of Core 62; rare and spotty Grantarhabdus meddii and Discorhabdus biradiatus; rare to few Zeugrhabdotus erectus and "Rhabdolekiscus" parallelus (which becomes more consistently present above Core 70); rare to common Discorhabdus ignotus, Percivalia fenestrata, Manivitella pemmatoidea, and Tetrapodorhabdus coptensis (which peaks in abundance just above the Hauterivian/Barremian boundary); rare to abundant Diazomatolithus lehmanii (which is most abundant in the lower part of the section); few to very abundant micrantholiths of a variety of shapes and forms; and an increasing variety and abundance of nannoconids.

Three previously unheralded events should be pointed out for this interval. The first is the LAD of rare to few but rather consistent Rhagodiscus swinnertonii $\mathrm{n}$. comb. in Core 603B-64. The second is the FAD in Sample 603B-60-1, 109-111 cm of a form we identify only as Eiffellithus? sp. 2 (Plate 22, Figs. 7-9) in that we have yet to isolate it in the SEM (this is not $E$. sp. 2 of PerchNielsen, 1979, 1985). Initially rare, this taxon becomes common in some lower Barremian samples and maintains a rather consistent presence before disappearing from the section toward the top of the Barremian. The third event to note is the appearance of rare to few specimens of a distinctive holococcolith, Zebrashapka vanhintei $\mathrm{n}$. gen., n. sp., beginning in the black shale Sample 603B$65-3,29-30 \mathrm{~cm}$. This new taxon becomes quite common uphole. We believe the occurrence of this dissolutionprone holococcolith species is strong evidence of redeposition of shallow-water coccoliths along with the black shales at this deep-water site. By the late Hauterivian, the site should have subsided to abyssal depths of about $4000 \mathrm{~m}$ (see Tucholke and Vogt, 1979, fig. 3). Further evidence of the shallow-water origin of $Z$. vanhintei is the fact that it tends to be present only in samples that contain nannoconids. Roth and Krumback (1986) conducted a biogeographic study of Atlantic and Indian Ocean middle Cretaceous nannofossils and found that the genus Nannoconus is indicative of neritic or shallow continental marine and epicontinental sea conditions.

The nannofossil Barremian/Aptian boundary has traditionally been marked by the FAD of Chiastozygus litterarius in combination with various other forms. Thierstein originally suggested placing the boundary at what he saw as a short overlap of $C$. litterarius with abundant Nannoconus colomii $(=N$. steinmannii $)$ and Micrantholithus hoschulzii, "both of which disappear abruptly" (Thierstein, 1971, p. 471). He later compressed this definition of the boundary to the FAD of $C$. litterarius and/or the LAD of N. colomii and/or the FAD of Hayesites (= Rucinolithus) irregularis (Thierstein, 1973). Roth $(1978,1983)$ suggested the FAD's of $C$. litterarius and Vekshinella matalosa.

Chiastozygus litterarius is an ill-defined species based on a sketch by Gorka (1957), the interpretation of which varies among nannofossil specialists. It is not the first chiastozygid with a multilath, fibrous crossbar to appear in the section. Marking its FAD requires an intuition we do not claim to possess. Forms that to us fit the various descriptions of the species can be traced as far down as Core 603B-62. The occurrence from that point on is spotty, consisting of rare to few specimens per sample at best. This also seems to be the case at more than a few other DSDP localities, such as Sites 417 and 419 (Gartner, 1980; Siesser, 1980). We noted few specimens that resembled Vekshinella matalosa and very few that could tentatively be attributed to Hayesites irregularis n. comb. The latter may be present at the very top of the nannofossiliferous section (Sample 603B-44-1, 56-57 cm), just below the barren interval that begins at the top of Core 44 where silty black claystones give way to variegated pelagic claystones (Fig. 3).

Common to abundant Micrantholithus hoschulzii/obtusus, Nannoconus colomii/steinmannii, and Conusphaera mexicana (an alternate Barremian subtop marker suggested by Roth, 1983) range as high as Sample $603 \mathrm{~B}-44-2,125-126 \mathrm{~cm}$. It could be argued that this sample should mark the nannofossil Barremian/Aptian boundary. The near synchronous presence/absence pattern of these three genera in Core 44 , however, suggests that where they do occur in this core, they all could be reworked.

A key to zoning Core 44 has been suggested to us by T. J. Bralower (personal communication, 1986), who examined samples from that core in considerable detail and noted the presence of Flabellites biforaminis. This species has not been reported below the Aptian.

Considering (1) the difficulties with the zonal markers discussed above, (2) the poor recovery from Cores 45,47 , and $48,(3)$ the loose nature of the sand that filled Core 46, and (4) the ever-present spectra of reworking uphole and contamination downhole in this part of the column, we see no reliable way to pick the Barremian/Aptian boundary in this hole. Habib and Drugg 
(this volume), however, are confident in their designation between Cores 47 and 46, based on palynomorphs. They report a significant break among the palynomorphs at this level that is not complicated by contamination, and we have no reason to disagree with their conclusion. From our point of view, the section above Core 47 could well be lowermost Aptian, particularly if Nannoconnus colomii/steinmannii and Micrantholithus hoschulzii/obtusus do indeed cross the boundary, as originally suggested by Thierstein (1971), or if there has been significant reworking here of these taxa into lower Aptian sediments.

One point is clear. The nannofossil assemblages from Cores 46 to 44 can be no younger than early Aptian because of the absence of the Aptian markers Lithastrinus floralis and Rhagodiscus angustus, whose FADs, according to Roth (1983), separate the lower from the middle Aptian. There is a form in the sequence, however, that does mimic $R$. angustus. This taxon, which we describe as Zeughrabdotus pseudoangustus $\mathrm{n}$. sp. (Plate 8, Figs. 2-4), ranges well down into the black shales of the Barremian (Sample 603B-57-1, 34-36 cm) where it is unlikely to be a contaminant (see "Systematic Paleontology" section for further discussion).

\section{Relation of New Taxa to Lithology}

The Barremian-lowermost Aptian nannoflora is quite similar to that of the Hauterivian, with a few notable exceptions aside from those discussed above. Significant, in our opinion, is the strong correlation between the frequency of Zebrashapka vanhintei n. gen., sp. (Plate 5, Figs. 4-7; Plate 6; Plate 7, Figs. 1-5), and cores with a high percentage of sand/silt turbidites. Whereas this taxon is prevalent from Section 603B-60-1 to Sample 603B-53,CC, which record a major rise and fall in turbidite activity, it is absent from Sections 603B53-2 to 603B-51-4 and in Core 49 where turbidite sands and silts are minimal (Fig. 3). It is again present, however, in Core 50 and in the interval from Core 48 to the lower part of Core 44, which brackets the massive sands at the top of Lithologic Subunit VA. As stated previously, we see the presence of this dissolution-prone holococcolith species as a good indicator of redeposition of sediment from shallower environments along the continental slope or shelf.

A new form that actually seems to characterize the black shales in the sand-dominated section above Core 603B-50 is Lithraphidites alatus magnus $\mathrm{n}$. ssp., which is an exceptionally large, irregular rod-shaped nannofossil (Plate 10, Figs. 3-4) that sometimes mimics its Cenomanian-Turonian relative, L. alatus alatus. As with Zebrashapka vanhintei, we suspect that this species is dissolution prone and is prevalent here only because it has been introduced along with the fine-grained turbidites. Otherwise, it probably would not be encountered in deep ocean sediments. This raises the possibility that similar Neocomian forms such as the erstwhile marker species Lithraphidites bollii may also be encountered in deep paleoenvironments only when introduced there by downslope processes.
Pickelhaube furtiva n. gen. (Plate 16, Figs. 1-2; Plate 23 , Figs. 1-2) is a third form with an apparent affinity for deep-water clastic turbidites. In our section, it occurs exclusively in black shales, and probably owes the preservation of its delicate proximal rim to a shallowwater origin and quick burial following redeposition. The fact that the centers of many specimens are partially or totally missing (e. g., Plate 23, Figs. 1-2) suggests breakage or dissolution during transport.

The abundance of a third species, Rucinolithus terebrodentarius $\mathrm{n} . \mathrm{sp}$. increases in a general way above Core 603B-62. This is a compact, chunky form that resembles the burr of a turn-of-the-century hand-held dental drill (Plate 17, Figs. 7-10; Plate 18, Figs. 5-7; Plate 19, Figs. 1-4). This form is apparently dissolution resistant, and its abundance does not seem to vary significantly with lithology or the prevalence of turbidites in the section. It is unusually abundant in the black shale samples of Core 44. With its numerous elements, this form superficially resembles Hayesites irregularis n. comb., (see "Systematic Paleontology" section for differentiation). It could be mistaken for the latter, and the prevalence of $R$. terebrodentarius in the upper Barremian might account for Roth's placement of the FAD of $H$. irregularis as low as the mid-Barremian (Roth, 1983).

\section{SUMMARY AND CONCLUSIONS}

The nannofossiliferous Lower Cretaceous section at Site 603 is complicated by (1) the presence of extensive terrestrial turbidite deposits in the upper Valanginianlowermost Aptian that resulted in reworking of older assemblages and (2) the potential for downhole contamination by loose sands caved from the top of the sequence. We have been only partially successful in applying the conventional nannofossil zones to this section. Difficulties encountered with some traditional zonal datums include: suggestions of dissolution susceptibility or evidence of provincialism (Calcicalathina oblongata); selective preservation or diagenetic alteration dependent on lithology (Cyclagelosphaera deflandrei); total ecologic exclusion (Lithraphidites bollii); vague taxonomic concept (Chiastozygus litterarius); mimicking by previously undescribed taxa Zeugrhabdotus? pseudoangustus $\mathrm{n}$. sp. for Rhagodiscus angustus; Rucinolithus terebrodentarius $\mathrm{n}$. sp. for Hayesites irregularis); and possible reworking by turbidites (Nannoconus colomii/steinmannii, Micrantholithus hoschulzii, and Conusphaera mexicana).

Some of the difficulties enumerated above, such as reworking, are peculiar to the continental margin environment of this site where turbidite activity was particularly intense. Such complications should be recognized and evaluated further as continental margin drilling proceeds. None of these various complicating factors, however, should be taken as an indication that the value of calcareous nannofossils is depreciated when it comes to age dating Neocomian sections. Such problems exist for all microfossil groups studied in Hole 603B.

Neocomian sections, however, are less frequently encountered by deep-sea drilling and are more difficult to 
obtain than the more widely studied mid- to Upper Cretaceous and Cenozoic sections. In essence, our experience with this section at Hole 603B points first toward work yet to be done. In particular, it emphasizes that attention needs to be focused on this part of the column, where there is the potential on a broad regional scale for mixing of nearshore and open-ocean nannofossil assemblages. Only then will the resolution of the nannofossil zonation for the Neocomian achieve that which has been attained for post-Aptian strata. We believe that we have identified taxa which, when they are better described and their ranges better documented, will be useful in refining Neocomian nannofossil stratigraphy. Of particular importance to such studies will be the detailed and careful correlation of the presence and abundance of individual taxa with lithology that in continental margin environments may vary drastically on a scale of only a few centimeters to meters (Fig. 4).

A second conclusion from our initial study of this section is that shallow-water Neocomian coccoliths can be identified in these turbiditic sections and that these provide an additional tool for interpreting the intensity of turbidite activity and the mode of deep-sea fan deposition. Dissolution-prone holococcolith species such as Zebrashapka vanhintei $\mathrm{n}$. sp., whose abundance correlates particularly well with the percent of silt/sand turbidites in the cores, are especially good indicators of downslope transport of shallow-water sediments into the deep-water environment. Taxa such as Lithraphidites alatus magnus n. ssp. and Pickelhaube furtiva n. gen. may also be good indicators of redeposition. The use of nannoconids per se as such an indicator, however, should be tempered by the fact that nannoconites that are clearly not turbiditic in origin can occur in deep-water sections as seen in Core 603B-35 (lithostratigraphic Unit IV).

Last, we can summarize our qualitative assessment of the Neocomian zonal markers used in the zonal compilation proposed by Roth (1983). Of the three co-markers for the base of NC3, Tubodiscus verenae and Calcicalathina oblongata enter the section within $30 \mathrm{~m}$ of each other rather than simultaneously, but establish consistent occurrence patterns thereafter. Diadorhombus rectus enters $10 \mathrm{~m}$ below $T$. verenae but, as noted by Roth (1983), is always rare and scattered in its occurrence, and is therefore not a consistent marker. Thus the first appearances in the section at Site 603 of this triad of index species for the base of NC3 occur over a 40-m interval in the following order: $D$. rectus, $T$. verenae, and $C$. oblongata. Perch-Nielsen (1985) reports a different order of appearance for these species, but T. J. Bralower (personal communication, 1986) has observed an order similar to ours in other sections where he also has paleomagnetic control. We arbitrarily chose the nominative species for the zone, $T$. verenae, as the basal marker for $\mathrm{NC} 3$ and also use it to approximate the Berriasian/Valanginian boundary.

There seem to be no reliable markers in this section for the NC3/NC4 boundary because Tubodiscus verenae becomes rare and ranges (is reworked?) higher in the section. Cyclagelosphaera deflandrei seems to be diage- netically controlled or, in effect, facies bound, and cannot serve as a reliable substitute marker.

The LAD of Cruciellipsis cuvillieri serves well as the marker for the NC4/NC5 boundary, if the possibility for reworking in the section is taken into account. We found, as did Roth (1983), that the FAD and LAD of Lithraphidites bollii cannot be used to subdivide Zones NC4 and NC5 in this part of the North American Basin, because this form does not occur here. It may be a predominantly Tethyan form that is confined to more tropical paleoenvironments and/or is essentially endemic to the eastern Atlantic-Tethyan region. Thierstein (1976) listed it as a tropical species, an assessment supported by Perch-Nielsen (1985). In addition, $L$. bollii may be dissolution susceptible and introduced into the deep-sea environment primarily by downslope processes. This would not have precluded it from reaching Site 603 , however, since turbidite activity was quite active at this locality during the late Hauterivian-early Barremian.

Within the Barremian of Zone NC5, Speetonia colligata and Calcicalathina oblongata seem to disappear from the section sequentially as suggested by Roth (1983, fig. 6; see also our Fig. 5). Hayesites irregularis, however, does not appear in the mid-Barremian, but is mimicked there by Rucinolithus terebrodentarius $\mathrm{n}$. $\mathrm{sp}$.

The NC5/NC6 boundary is quite difficult (if not impossible) to place within this section because of taxonomic problems associated with Chiastozygus litterarius as well as the wholesale reworking or extended ranges of Nannoconus colomii and Conusphaera mexicana. As opposed to Roth (1983), Perch-Nielsen $(1979,1985)$ places the LAD of the latter at the mid-Aptian.

Because of the absence of Lithastrinus floralis, we conclude that nannofossiliferous strata of Zone $\mathrm{NC7}$ were not recovered in this hole. However, Zeughrabdotus pseudoangustus $\mathrm{n}$. $\mathrm{sp}$., a form that closely mimics the basal co-marker for that zone, Rhagodiscus angustus, extends well down into the Barremian, thus depreciating the value of $R$. angustus as a useful index fossil.

\section{SYSTEMATIC PALEONTOLOGY}

Species treated here are also listed in Appendixes A and B. See "Methods, Zonation, and Species Considered" above for sources of the taxonomic citations that are not listed in the references to this chapter. All taxa below are arranged alphabetically by generic epithets.

\section{Genus BISCUTUM Black in Black and Barnes, 1959}

Biscutum sp. 1

(Plate 2, Figs. 4-7; Plate 3, Figs. 1, 2)

Remarks. These forms resemble closely those figured by Covington (1985, fig. 2) from the Niobrara Formation (Upper Cretaceous) of Kansas. Covington coined the term "coccocylinder" to describe the unusual, elongate shape of the tests. We illustrate specimens from the Barremian. Although not as elongate as some of those from the Niobrara Formation, these are the oldest coccocylinders yet found.

Genus CRETARHABDUS Bramlette and Martini, 1964

Cretarhabdus? delicatus Applegate, Covington, and Wise, n. sp. (Plate 16, Figs. 3, 4)

Description. Single-cycle cruciellipsidlike rim with prominent multilath, central spine atop an axial cross, the quadrants between which are filled along the outer periphery by 8 to 10 thin, delicate parallel 
laths oriented $45^{\circ}$ to the major and minor axes. Within the inner portions of each quadrant, the spaces between the parallel laths are filled by calcite.

Remarks. Round perforations may decorate the inner margins of each distal shield element. The central area is similar to that of Pickelhaube furtiva $\mathrm{n}$. comb., which indicates an affinity between these two species. The single-cycle rim is more similar to that of Cruciellipsis than to Cretarhabdus, which Black (1972) would confine to two-cycle rims; however, the central area is much larger than that of Cruciellipsis. The inner half to two-thirds of each quadrant is filled in by calcite as seen in some cretarhabdids (e.g., Thierstein, 1971, plate VI, figs. 1-6), but not in species of Polypodorhabdus. The spokelike laths, however, resemble somewhat those in Polypodorhabdus. This and similar forms with fewer elements (Plate 15, Fig. 4) do not fit well at the ultrastructural level into existing genera. The form described here may be an end member of a larger plexus.

Occurrence. Hauterivian to lower Aptian, DSDP Hole 603B.

Size. Holotype: $12.1 \times 10.6 \mu \mathrm{m}$.

Holotype. Plate 16, Figure 4.

Paratype. Plate 16, Figure 3.

Type locality. DSDP Sample 603B-60-1, $109 \mathrm{~cm}$.

\section{Genus CYCLAGELOSPHAERA Noël 1965}

Cyclagelosphaera jiangii Covington and Wise, n. sp. (Plate 9, Fig. 4)

Diagnosis. A small species of Cyclagelosphaera with a deeply recessed central cycle consisting of about a dozen separate, spokelike laths offset somewhat from the center point to form a counterclockwise gyre. The central laths are separated by spaces approximately equal to their widths.

Description. The diameter of the central cycle is about $35 \%$ that of the coccolith. The central laths may curve slightly and are offset from the center point to form a gyre. The outer two cycles consist of about 30 elements. The middle cycle is about half the width of the outer cycle.

Remarks. Named in honor of Jiang Yan Wen, People's Republic of China. The deeply recessed central area and its well separated, spokelike elements distinguish this taxon from other species of Cyclagelosphaera.

Occurrence. Rare in the Valanginian of DSDP Hole 603B, lower continental rise of the North American Basin.

Size. Holotype $4.3 \mu \mathrm{m}$ in diameter.

Holotype. Plate 9, Figure 4.

Type locality. DSDP Sample 603B-76-1, $136 \mathrm{~cm}$.

\section{Genus DISCORHABDUS Noël, 1965}

Discorhabdus biradiatus (Worsley) Thierstein ex Applegate, Covington, and Wise

(Plate 14, Fig. 11)

Rucinolithus? biradiatus Worsley, 1971, p. 1311, pl. 1, figs. 53, 54 (non pl. 1, figs. 51, 52) (Invalid, ICBN Art. 34.4).

Discorhabdus biradiatus (Worsley) Thierstein, 1973, p. 42, pl. 6, figs. 7-11 (Invalid, ICBN Art. 33.2).

non Rucinolithus? radiatus Worsley, 1971, pp. 1311-1312, pl. 1, figs. 51, 52 (non pl. 1, figs. 53, 54) (Invalid, ICBN Art. 34.4).

Explanatory note. Worsley (1971, p. 1311) described this taxon in his text, but cited there as illustrations his plate 1 , figures 51 and 52 . Thierstein (1973) referred to the same illustrations in transferring the species to Discorhabdus. The illustrations in Worsley's plate 1, figures 51 and 52 , however, are of a different new species, Rucinolithus? radiatus, and are so labeled in the figure caption. The illustrations for $R u$ cinolithus? radiatus are also misreferenced on p. 1311 of the text as plate 1, figures 53 and 54 , but are labeled correctly in the figure caption. A strict interpretation of ICBN Article 34.4 (Stafleu et al., 1978) would render both of Worsley's new species invalid because two different names have been proposed simultaneously for each taxon.

It is clear from his written description that Worsley (1971) intended the specimen depicted in his plate 1, figures 53 and 54 to serve as the paratype and holotype, respectively, for his Rucinolithus? biradiatus. To allay any doubts, we therefore accept these illustrations as valid for this taxon and reject those in his plate 1, figures 51 and 52 . We also accept the name Rucinolithus? biradiatus for these specimens and reject
Rucinolithus? radiatus, thereby validating the former name in accordance with the procedure mentioned in Stafleu et al. (1978, p. 33). These same illustrations, then, should be accepted for the basionym of Theirstein's (1973) new combination, Discorhabdus biradiatus (Worsley), which we also validate here.

We do not deal further here with Worsley's Discorhabdus radiatus. That taxon will be treated in a subsequent publication (J. L. Applegate and J. A. Bergen, personal communication, 1986).

\section{Genus EIFFELLITHUS Reinhardt, 1965, emend. Reinhardt, 1966} Eiffellithus? sp. 1

?Eiffellithus sp. Wind and Čepek, 1979, p. 229, pl. 10, figs. 5-13.

Remarks. Few to rare in scattered samples from the Hauterivian to the lower Aptian. Not observed in the SEM, thus no further details of its structure can be provided.

\section{Eiffellithus? sp. 2 \\ (Plate 22, Figs, 7-9)}

Remarks. This taxon has a short range concentrated mostly in the lower Barremian. It appears to have an eiffellithalid rim and a central cross that birefringes brightly in polarized light. Unfortunately, it has not been observed in the SEM.

\section{Genus ETHMORHABDUS Noël, 1965}

Ethmorhabdus? hauterivianus (Black) Applegate, Covington, and Wise, n. comb.

(Plate 14, Figs. 2-5)

Cribrosphaera hauteriviana Black, 1971, p. 421, pl. 33, fig. 8. Ethmorhabdus gallicus Noël, Wind and Cepek, 1979, p. 229, pl. 6, figs. 7-12.

Cribrosphaerella? hauteriviana (Black) Perch-Nielsen, 1984, p. 43.

Remarks. Wind and Cepek (1979) considered this Lower Cretaceous form conspecific with Ethmorhabdus gallicus Noël from the Jurassic. We find that the rim structures of the two taxa are identical and quite different from that of Cribrosphaerella. The only significant difference is that the rhabdolith structure is strongly or totally suppressed in the Lower Cretaceous form, and that the remanent of this structure, if present at all, is represented only by a few larger elements that seem to cover the center (Black, 1971, pl. 33, fig. 8). The presence of such a structure is dificult to determine for most specimens because their centers are usually broken out. If there is no remnant of a central spine, then the generic definition would have to be emended to accommodate properly this Cretaceous descendant of E. gallicus.

Genus HAYESITES Manivit, 1971, emend. Applegate, Covington, and Wise

Type species. Hayesites albiensis Manivit, 1971.

Emended diagnosis. Star-shaped to compact petaloid nannoliths composed of about 6 to 11 dextrally imbricate elements, the size of which may vary. Profile flat to somewhat conical on the distal side; a multielement central process generally present.

Remarks. The emended diagnosis accommodates within the single genus the lineage extending from $H$. irregularis $\mathrm{n}$. comb. to $H$. albiensis as described by Thierstein (1973). Otherwise, this lineage must be split between two genera, Hayesites Manivit and Rucinolithus Stover. Aside from forming a coherent evolutionary lineage, members of Hayesites emend. differ from most other described species of Rucinolithus by having dextrally imbricate rather than sinistrally imbricate ray elements, a major evolutionary departure that seems to have originated with $H$. irregularis during the early Aptian. Excluded from the genus as emended is "Hayesites" bulbus Thierstein (1973) (= "Rucinolithus? radiatus" Worsley, 1971), which will be reassigned in a future publication (J. L. Applegate and J. A. Bergen, personal communications, 1986).

\section{Hayesites irregularis (Thierstein) Applegate, Covington, and Wise,} n. comb.

Basionym. Rucinolithus irregularis Thierstein in Roth and Thierstein, 1972, p. 438, pl. 2, figs. 10-19.

Remarks. Manivit (1971) described Hayesites as a monospecific genus and, for the description of the type species, referred the reader 
to the generic description except for the dimensions. Of the other species since attributed the genus, only $H$. irregularis n. comb. exhibits a close similarity in ultrastructure of the generotype (see also "remarks" following the generic description above).

\section{Genus LITHRAPHIDITES Deflandre, 1963}

Lithraphidites alatus alatus Thierstein, 1972

Lithraphidites alatus Thierstein, in Roth and Thierstein, 1972, p. 438, pl. figs. 1-8.

\section{Lithraphidites alatus Thierstein, 1972 ssp. magnus Covington and Wise n. ssp.} (Plate 10, Figs. 3, 4)

Diagnosis. A subspecies of Lithraphidites alatus distinguished by its exceptionally great width and robust size.

Differentiation. The holotype is at least $6.75 \mu \mathrm{m}$ wide as measured on a scanning electron micrograph ( $\mathrm{Pl}$. 10, Fig. 3) in which the specimen is foreshortened due to the tilt of the specimen stage. The paratype, represented by another foreshortened image, is at least $5.7 \mu \mathrm{m}$ wide. The maximum width of the holotype of $L$. alatus alatus is about $5.2 \mu \mathrm{m}$, whereas that of the paratype is about $4 \mu \mathrm{m}$. A specimen illustrated by Manivit et al. (1977) measures about $4.1 \mu \mathrm{m}$ in width. The specimens of the new subspecies we observed are in general noticeably larger than the those of $L$. alatus alatus described from the mid-Albian-Cenomanian.

A second difference between the two subspecies seems to be in their shape, although this is more difficult to define because of diagenetic alteration (etching) of most published specimens. Lithraphidites alatus alatus has been discribed as being shaped more or less like an umbrella with the curved portion of the handle removed. The widest point of the nannofossil is at the flared end of the umbrella immediately adjacent to the "handle." The outline of $L$. alatus magnus appears to be more like a wide bladed dagger, the blade of which maintains a constant width extending some distance from the "handle," perhaps even widening a bit before tapering toward the point. The holotype of $L$. alatus magnus appears to be widest toward the midpoint rather than at the flared end immediately adjacent to the "handle" (lower left in Pl. 10, Fig. 3).

Remarks. Lithraphidites alatus magnus is characteristically found in the black shales, silts, and sandstones of the sand-dominated part of the section in Hole 603B above Core 51. This could indicate that it is a shallow-water form introduced at this site via turbidites.

Occurrence. Rare to common in the upper Barremian to lowermost Aptian of DSDP Hole 603B. North American Basin. long.

Size. Holotype: a minimum of $5.7 \mu \mathrm{m}$ wide; an estimated $20 \mu \mathrm{m}$

Holotype. Plate 10, Figure 3

Paratype. Plate 10, Figure 4.

Type locality. DSDP Sample 603B-44-1, $97 \mathrm{~cm}$.

\section{Genus OCTOPODORHABDUS Noël, 1965, emend. Wind and Cepek, 1979 \\ Octopodorhabdus plethotretus Wind and Cepek ex Applegate, Covington and Wise \\ (Plate 13, Figs. 8, 9)}

non Zygolithus fenestratus Stover, 1966, p. 147, pl. 3, figs. 21, 22, pl. 4 , fig. 1 ; pl. 8 , fig. 24 .

Perissocyclus fenestratus (Stover) Black, 1971, p. 406, pl. 32, fig. 4. Octopodorhabdus plethotretus Wind and Cepek, 1979, p. 4 (Invalid, ICBN Art. 34.4).

Octopodorhabdus polytretus Wind and Cepek, 1979, pl. 4, figs. 1-5 (plate explanation) (Invalid, ICBN Art. 34.4)

Octopodorhabdus polytretus Roth, 1983, p. 612 (Invalid, ICBN Art. 34.4).

Explanatory note. Wind and Čepek (1979 p. 230) described this taxon in their text under the name Octopodorhabdus plethotretus, but listed it under the name $O$. polytretus in their plate explanation (1979, p. 240). Steinmetz (1984b, p. 78) considered this error sufficient to invalidate the name under ICBN Article 34.4, which prohibits the simultaneous proposal of alternative names. As Wind and Cepek (1979, p. 230) give the full Greek derivation of plethotretus but make no further mention of polytretus, it was clearly not their intention to propose the latter as an alternative name. However, in order to ensure that this useful and well described taxon is returned to the active literature, we republish Wind and Cepek's original description of $O$. polytretus, thereby validating that name in accordance with the procedure mentioned in Stafleu et al. (1978, p. 33). At the same time, we hereby reject the name $O$. polytretus for this taxon. The following, then, is from Wind and Cepek (1979).

Description. A species of Octopodorhabdus with two or more cycles of large perforations in the inner area. More than eight perforations surround the stem in the central area. Most windows are located in a single cycle along the outer edge of the central ara and around the base of the stem. Additional windows may be present between the outer cycle and the set of four that ring the stem. Buttresses supporting the stem and delineating the central area perforations may or may not be positioned in a symmetrical fashion with respect to the axes of the ellipse.

Remarks. The species name is from the Greek plethos $=$ great number; tretos $=$ perforated. This species is distinguished from Octopodorhabdus decussatus (Manivit) by its greater number of perforations. The forms illustrated in Stover (1966) demonstrate a nonpodorhabdid rim construction especially in cross-polarized light; these forms are probably related to the genus Cretarhabdus. Some specimens, such as those illustrated in plate 4 , figure 4 (Wind and Cepek, 1979), and in Black (1971, pl. 32, fig. 4) have central area windows whose general size and positioning with respect to the rim resembles corresponding features on specimens of Perissocyclus noeliae Black, 1971, emend. Wind and Cepek (1979).

On the light microscope, it is often difficult to identify central area perforations other than those of the other cycle. The four inner windows of the holotype were not known to exist until the specimen was transferred to the SEM.

Occurrence. This species is fairly common in well-preserved samples from the Hauterivian of DSDP Hole 397A, and is present in the Barremian of England.

Size. Maximum length 9.8 to $11.8 \mu \mathrm{m}$. Holotype $11.0 \mu \mathrm{m}$.

Holotype. USNM 256046 (plate 4, fig. 1-3 [Wind and Čepek, 1979]).

Isotypes. USNM 256047, 256048 (Wind and Čepek, 1979).

Type locality. Eastern Atlantic Ocean, DSDP Sample 397A-46-3, $58-58 \mathrm{~cm}(1394 \mathrm{~m})$.

Genus PERISSOCYCLUS Black, 1971

Perissocyclus? sp. cf. P. noeliae Black, emend. Wind and Cepek, 1979

(Plate 14, Fig. 1)

Remarks. The central area of this small specimen closely resembles $P$. noeliae except for the high and rather strongly imbricate rim, which appears to be more of an eiffellithid than a podorhabdid rim. Perhaps it is this type of rim that produced the highly birefringent margin of the specimens of Zygolithus fenestratus illustrated by Stover (1966).

\section{Genus PICKELHAUBE Applegate, Covington, and Wise, n. gen.}

Type species. Pickelhaube furtiva (Roth) Applegate, Covington, and Wise, emend., n. comb.

Diagnosis. Helmet-shaped nannofossils with a widely expanded and delicate proximal shield composed of wide, nonimbricate elements that yield an extinction figure reminiscent of the Tertiary genus Reticulofenestra. A smaller but distinct distal rim is brighter in polarized light than the flaring proximal shield, and may support a central, multilath cross surmounted by a spine. Each central area quadrant is filled by a grill work of narrow, parallel laths oriented $45^{\circ}$ to the major axis.

Remarks. The name is adopted directly from the German, meaning "spiked helmet." Forms complete with central area cross and spine resemble the military helmets worn by the German emperors and their officers (1871-1918).

Pickelhaube furtiva (Roth) Applegate, Covington, and Wise, emend. $n$. comb.

(Plate 16, FIgs. 1, 2; Plate 23, Figs. 1, 2)

?Cruciplacolithus hayi Black, Köthe, 1982, partim, pl. 7, fig. 14 (non fig. 15).

Cruciplacolithus furtivus Roth, 1983, p. 609, pl. 6, figs. 1-4. 
Emended Diagnosis. A species of Pickelhaube consisting of a flaring proximal shield composed of a single cycle of nonimbricate, delicate elements, and a distinct but smaller distal rim that supports a multilath spine atop a central cross aligned roughly parallel to the major and minor axes. A grill, consisting of thin parallel spokes inclined to the major and minor axes as in the genus Polypodorhabdus, connects the cross arms with the rim.

Description. Roth (1983) provides an excellent description of the species based on his light microscope observations, which we supplement here with details of the ultrastructure based on SEM micrographs (Plate 16, Figs. 1, 2; Plate 23, Fig. 1). The proximal shield consists of 30 to 40 wide but thin, nonimbricate elements that flare proximally to form a smooth, delicate base. In polarized light, this produces an extinction figure reminiscent of that of Reticulofenestra (Roth, 1983, p. 609).

The thick, narrow distal rim consists of an equal number of elements, each supported below by a columnarlike buttress that connects it to the corresponding element of the proximal shield. In cross-polarized light, the distal rim is considerably brighter than the proximal shield, and the individual elements and corresponding buttresses are distinctly visible (Plate 23, Fig. 2), presenting a slightly serrated appearance along the outer margin of the distal rim.

The central cross has a parallel, multilath construction, and is aligned parallel to or slightly off center from the major and minor axes. The prominent spine also consists of parallel laths and is a direct extension of the cross. In each central area quadrant, 6 to 10 parallel spokes of the central area grill intersect the distal rim. These spokes are not simple, single-element laths, but seem to consist of two closely appressed parallel laths. Toward the interior, the spaces between the spokes are filled in and the grill is covered by additional laths of the same general orientation.

The size of the central area relative to the proximal shield seems to be variable, as does the prominence of the central area cross and spine. These latter may be missing in some specimens due to differential preservation.

Differentiation. Roth (1983) tentatively placed in synonymy with this species certain specimens attributed by Hill (1976) and Köthe (1982) to Cruciplacolithus hayi. We do not include those specimens in the synonymy here because their central areas are more symmetrical and elliptical in outline, less quadrate in cross-polarized light, and generally larger in proportion to the overall size of the coccolith. We do place tentatively into the synonymy, however, a different specimen illustrated by Köthe (1982), which has a birefringent shield and a central area proportioned more like that of $R$. furtiva.

Remarks. The extinction pattern of this species, particularly that of the isolated proximal shield, is so similar to that of some Teritary reticulofenestrids (such as Recticulofenestra samodurovii) that one might dismiss it in Lower Cretaceous drill hole sections as a probable Tertiary downhole contaminant. That possibility was virtually eliminated in our section by the fact that the overlying Paleogene to midMiocene section in Hole 603B was barren of coccoliths, and the more nannofossiliferous portion of the Neogene section (where coccoliths were never highly abundant) was cased off long before the hole penetrated Cretaceous strata.

\section{Genus RHABDOLEKISKUS Hill, 1976 "Rhabdolekiskus" parallelus Wind and Čepek, 1979 (Plate 23, Figs. 3-5)}

Eurhabdus luciformis Reinhardt, Wilcoxon, 1972, pl. 10, fig. 4. Rhabdolekiskus parallelus Wind and Čepek, 1979, p. 232, pl. 3, figs. 3-6.

Remarks. We agree with Perch-Nielsen (1985, p. 418) that this taxon should be reassigned from Rhabdolekiskus, which is defined as having a stem that diminishes in width at either end (Hill, 1976). Beyond that, we considered Rhabdolekiskus at best a junior synonym of Rhabdophidites Manivit, whereas Perch-Nielsen (1985) places it into synonymy with Lithraphidites Deflandre. However, until the construction of the base of Rhabdolekiskus" parallelus is better understood, we have no sound basis for selecting the correct genus. At present, we have only been able to determine that the base has an eiffellithalid rim.
Genus RHABDOPHIDITES Manivit, 1971

Synonym. Rhabdolekiskus Hill, 1976.

Rhabdophidites aquitanicus (Manivit) Applegate, Covington, and Wise, n. comb.

(Plate 11, Fig. 3)

Rhabdolithus aquitanicus Manivit, 1971, p. 124, pl. 23, figs. 1-3. Rhabdolekiskus aquitanicus (Manivit) Hill, 1976, p. 153, pl. 8, figs. 10-14; pl. 14, fig. 17.

Remarks. The micrographs by Hill as well as that in our Plate 11, Figure 3 show that the stem of this species is constructed like that of Lithraphidites, but that, in addition, there is a small circular base at the end. The construction of the stem is not readily evident in Manivit's holotype of Rhabdolithus aquitanicus, the blades of which lie at $45^{\circ}$ to the SEM stub so that only two blades are visible. Earlier in her manuscript, however, Manivit (1971) had erected a genus to accommodate such forms based on a different taxon (Rhabdophidites moeslensis). In erecting their respective genera, she (1971) and Hill (1976) noted the similarity of the stem to Lithraphidites.

Perch-Nielsen (1985, p. 418) considers both Rhabdolekiskus Hill and Rhabdophidites Manivit conspecific with Lithraphidites in that the stems of all of these are identical. Forms with a small but perfectly centered terminal base, however, have been reported now in several studies, including the present one, and may represent more than mere artifact. Manivit's and Hill's specimens were from the Albian; ours is from the Barremian. If these terminal bases, however, can be proven to be an integral but rarely preserved part of Lithraphidites, then PerchNielsen's conclusion would be valid, and the generic definition of Lithraphidites could then be emended to accommodate all such taxa.

\section{Genus RHAGODISCUS Reinhardt, 1967}

Synonym. Mitosia Worsley, 1971

Remarks. Both Rhagodiscus and Mitosia are defined as having an elevated rim with a central area composed of granular calcite.

\section{Rhagodiscus infinitus (Worsley) Applegate, Covington, and Wise, n. comb.}

Mitosia infinitae Worsley, 1971 , p. 1311, pl. 1, figs. 48-50.

Parahabdolithus infinitus (Worsley) Thierstein in Roth and Thierstein, 1972 , p. 437 , pl. 9, figs. 7-16.

Remarks. Although Worsley (1971) established a monospecific genus for this taxon, it was later transferred to Parahabdolithus where it resided with similarly constructed Cretaceous forms such as Parhabdolithus splendens (Stradner) and Parhabdolithus angustus (Stradner). These latter forms, however, do not possess the primitive proximal shield described by Prins (1969) for the generotype, Parhabdolithus liasicus Deflandre, and were subsequently transferred to Rhagodiscus. As Rhagodiscus infinitus $\mathrm{n}$. comb. also exhibits a granular central area (as indicated by Worsley, 1971, and subsequently shown by Thierstein's micrographs (Roth and Thierstein, 1972, pl. 9, figs. 7 and 13; see also, Plate 7, Fig. 9 of this report), this taxon is similarly transferred. The major difference between this and the other species assigned to the genus are the large, flaring central process (Wise and Wind, 1977 , pl. 56, figs. 5, 6) and the two larger openings along the major axis that form the "infinity sign."

\section{Rhagodiscus swinnertonii (Black) Applegate, Covington, and Wise, n. comb.}

Rhabdolithia swinnertonii Black, 1971, p. 418, pl. 34, fig. 4.

Parhabdolithus boletiformis Black, 1972, pp. 29-30, pl. 3, figs. 3, 4; pl. 4 , figs. 1-3.

Parhabdolithus swinnertonii (Black) Wind and Čepek, 1979, p. 231, pl. 11, figs. 8-16.

\section{Genus RUCINOLITHUS Stover, 1971}

Rucinolithus terebrodentarius Applegate, Bralower, Covington, and Wise, n. sp.

(Plate 17, Figs. 7, 8; Plate 18, Figs. 5-7; Plate 19, Figs. 1-4) 
Diagnosis. A globular to oblate spheroid composed of about 10 blocky, euhedral interpenetrating elements (counted along the periphery) that may or may not appear to rotate or spiral about a polar axis.

Description. This globular object consists of interpenetrating elements that may rotate or spiral (usually counterclockwise) about a central axis. A terminal element may project as a knob at a pole (Plate 18 , Figs. 5-7), so that when viewed axially, the object appears as a rosette in plan view as is characteristic of the genus (Stover, 1966, p. 154). Specimens exhibit about 10 (Plate 18, Fig. 7) elements per whorl and one (Plate 18, Fig. 7) to two (or more?) (see Plate 19, Fig. 3) whorls per individual. There is variation in the regularity by which the elements are inserted, so that a definite rotation or spiral about an axis cannot always be demonstrated on single micrographs of a specimen.

Remarks. This compact, chunky form resembles the burr of a turnof-the-century hand-held dental drill, hence the trivial name (from the Latin, meaning "tooth borer"). The insertion of the elements, however, is more radial in some specimens. The form is apparently dissolution resistant in that its abundance does seem to vary significantly with lithology or the prevalence of turbidites in the section. It is unusually abundant, however, in black shale samples from Core 44 .

Differentiation. The taxon was described after we completed our range chart (Table 1), therefore it is not distinguished there from Assipetra infracretacea (Thierstein) Roth, another compact form that consists of "two sets of flat crystal plates, one set piercing the other at an obtuse angle" (Thierstein, 1973, p. 46). Rucinolithus terebrodentarius $\mathrm{n}$. sp. is more globular, has more numerous and angular projecting elements, and often displays a regular, spiral construction not observed in $A$. infracretacea, the outline of which is subrectangular to suboval (Thierstein, 1973).

In the light microscope, $R$. terebrodentarius is highly birefringent, and can therefore be distinguished readily from Hayesites irregularis, which exhibits a first-order gray birefrengence. Specimens of $H$. irregularis reported from the mid-to upper Barremian by Roth (1983, fig. 6) may be this new species.

Occurrence. Rare to abundant in the Barremian-lower Aptian, Hole $603 \mathrm{~B}$, increasing in numbers upsection.

Size. 5 to $8 \mu \mathrm{m}$; holotype, $7.7 \mu \mathrm{m}$.

Holotype. Plate 18, Figure 7.

Paratypes. Plates 17, Figures 7-8; Plate 18, Figures 5, 6; Plate 19, Figures 1-4.

Type locality. DSDP Sample 603B-44-1, $113 \mathrm{~cm}$.

\section{Genus STEPHANOLITHION Deflandre, 1939 Stephanolithion laffittei Noël, 1956 (Plate 20, Figs. 8, 9)}

Remarks. The specimens illustrated exhibit exceptionally good preservation, revealing thin elements separated by thin, subparallel ridges. Only a few elements are thickened, and the supplemental calcite (overgrowths?) is confined to their distal portions (Plate 20, Fig. 9).

\section{Genus WATZNAUERIA Reinhardt, 1964}

\section{Watznaueria fasciata Wind and Čepek, 1979}

(Plate 9, Fig. 8?; Plate 10, Figs. 1, 2)

Remarks. The coccospheres illustrated display about 15 to 20 coccoliths per cell. The specimen in Plate 9, Figure 8 may be a member of this species in which the bars across the central area have been overgrown by secondary calcite. If not diagenetically altered, however, it could be considered a new species.

\section{Genus ZEBRASHAPKA Covington and Wise, n. gen.}

Type species. Zebrashapka vanhintei Covington and Wise, n. sp. Diagnosis. Compact holococcoliths with a suboval base from which the bodies of the coccoliths expand somewhat in the distal direction to form tall hatlike objects. In cross-polarized light the internal structure produces a regular set of birefringent lines subparallel to the base to yield a pattern that resembles the stripes of a zebra.

Remarks. The second part of the name, adopted directly from the Russian, refers to a type of winter hat. The holococcolith construction is evident by the aggregation of fine cubes. This is the only holococcolith group with these peculiar optical properties yet described and, at present, is a monospecific genus. Other Mesozoic holococcolith genera have been described in Wise and Wind (1977), Wind and Cepek
(1979), and Hattner and Wise (1980). Wind and Čepek (1979) described the earliest known Lower Cretaceous forms from the Hauterivian. Forchheimer and Stradner's (1973) suspicion that Scampanella is a Cretaceous holococcolith has not been confirmed by subsequent electron microscope studies.

\section{Zebrashapka vanhintei Covington and Wise, n. sp.}

(Plate 5, Figs. 4-7; Plate 6; Plate 7, Figs. 1-5)

Description. From the suboval base, this compact holococcolith expands somewhat in the proximal direction so that the sides flare slightly outwards. It rises to a height that varies from roughly one half to twice the width of the base. Partially etched specimens reveal that the sides (but not the distal surface) are veneered with at least two layers of fine cubes. The cubes in each layer of the veneer near the base are aligned in rows that form an angle with the basal surface of between 55 and $70^{\circ}$, but the rows of each layer are inclined in opposite directions so that they crisscross each other. Beneath the outer veneer, the internal structure is composed of regular rows of cubes arranged in layers that are roughly but not strictly parallel to the basal surface. Measured along the etched sides of the coccoliths, there are on average between five and seven rows or layers of cubes per micrometer.

Viewed laterally in cross-polarized light, the internal rows of cubes produce a set of about a dozen highly birefringent lines subparallel to the basal surface and separated from each other by dark lines so that they yield a pattern similar to the stripes of a zebra. In lateral view, there are two to three birefringent lines per micrometer, which is somewhat less than half the numbers of rows of cubes measured on the electron micrographs. The veneer along the sides (and base?) is not in optical continuity with the internal structure and, therefore, produces a bright border in lateral view. The total optical effect renders an object that resembles a traditional Russian winter hat or a modern-day drum major's hat (Plate 6, Figs. 7-9; Plate 7, Figs. 1-5).

Remarks. Named in honor of Professor Jan E. van Hinte, Cochief Scientist on DSDP Leg 93.

Occurrence. Rare to abundant in the upper Hauterivian to lowermost Aptian in DSDP Hole 603B, North American Basin.

Size. Holotype: $4.4 \mu \mathrm{m}$ long across the base, $6 \mu \mathrm{m}$ long across the distal surface, and $4 \mu \mathrm{m}$ high; paratypes, 4 to $5.5 \mu \mathrm{m}$ long across the base, 5 to $7.5 \mu \mathrm{m}$ long across the distal surface, and 3 to $6.5 \mu \mathrm{m}$ high.

Holotype. Plate 5, Figure 6; Plate 6, Figure 3.

Paratypes. Plate 5, Figures 4, 5, 7; Plate 6, Figures 1, 2, 4-9; Plate 7, Figures 1-5.

Type locality. DSDP Sample 603B-57-2, $131 \mathrm{~cm}$.

\section{Genus ZEUGRAHBDOTUS Reinhardt, 1965}

\section{Zeugrhabdotus? pseudoangustus Bralower, Applegate,} Covington, and Wise, n. sp.

\author{
(Plate 8, Figs. 2-4)
}

Rhagodiscus cf. $R$. angustus, Perch-Nielsen, 1979, p. 229, fig. 3.

Description. Outline subrectangular with parallel sides and squared to rounded ends; length to width ratio $2: 1$. A high, eiffellithalid rim is composed of about 30 to 40 elements imbricated clockwise. A bridge spans the minor axis and is built around a large central opening. Two large openings lie on either side of the bridge along the major axis. As yet, no evidence of a proximal or basal cover has been observed across these openings, although their apparent absence could be a function of preservation.

Remarks. Zeugrhabdotus pseudoangustus mimics in size and general shape Rhagodiscus angustus (Stradner) but occurs lower in the geologic column, displays no discernible granular covering over the proximal surface, and may have a more rectangular outline. As seen in electron micrographs, the high eiffellithalid rim rises vertically from the base rather than flaring to some degree outwards as in Rhagodiscus angustus (compare with Roth and Thierstein, 1972, pl. 6, fig. 18; and Hattner and Wise, 1980, pl. 29, fig. 9). In $R$. angustus the rim is also proportionately thinner, and the central opening is apparently smaller, occupying only the middle third of the bridge. A similar form mentioned by Perch-Nielsen (1979, p. 229) from the Hauterivian of the Speeton Clay is probably this new species.

Most other taxa of assemblages observed along with this new species in black shale and sandstone samples are well preserved. Thus if there is any covering over the basal surface of Z.? pseudoangustus, it must be quite fragile and seldom preserved. It is also possible that this 
species was introduced from shallower environments to the deep-water environment of Hole 603B by carbonaceous mud or sand turbidites.

Because the new species closely resembles Rhagodiscus angustus, the value of the latter as an index species for the mid-Aptian is diminished. The alternate marker for the Rhagodiscus angustus Zone suggested by Thierstein (1973), Lithastrinus floralis Stradner, therefore becomes relatively more useful. In practice, the FAD of $L$. floralis has already been found to be more suitable in many other parts of the world (e.g., Wise, 1983).

Occurrence. Rare to few in the Barremian-lower Aptian of DSDP Hole 603B; may range down into the Hauterivian (see Perch-Nielsen, 1979 , p. 229).

Size. $5 \mu \mathrm{m}$ long, $2.5 \mu \mathrm{m}$ wide.

Holotype. Plate 8, Figure 2.

Paratypes. Plate 8, Figures 3, 4 .

Type locality. DSDP Hole 603B-44-1, $97 \mathrm{~cm}$.

\section{Genus et species indet. 1}

(Plate 22, Fig. 6)

Description. Elliptical, discoidal coccolith with a sievelike proximal surface formed by numerous fine, closely spaced perforations arranged in a hexagonal array. The perforations apparently extend to the rim, but on the figured specimen, those along the outer portion of the proximal surface are partially or totally obscured by a covering of secondary calcite or clay. The general shape of the nannolith is similar to species of Rhagodiscus Reinhardt or Percivalia Black, none of which display the regular hexagonal pattern of fine perforations exhibited by this specimen. Unfortunately, the structure of the rim of the specimen cannot be discerned.

\section{Genus et species indet. 2}

(Plate 23, Figs. 6, 7)

Rhabdolith with possible affinity to Diadorhombus rectus Worsley, Wind and Cepek, 1979, explanation for pl. 3, figs. 7, 8 .

Description. Straight-sided rhabdolith with a small, flat base at the proximal end, and a large, massive ornament on the distal end. The large ornament consists of approximately six somewhat misshapened rhombs that intersect in the center along a small central canal. As such, the distal end of the object is somewhat reminiscent of Hexalithus, particularly of the stemmed specimens conferred by Wiegand (1984, pl. 1, figs. 1-4) to $H$. magharensis.

Remarks. Only one specimen of this rare form was noted, but it closely resembles the distal portion of the specimen figured by Wind and Cepek (1979). Until more is known about the construction of the base, the taxon cannot be further classified.

\section{ACKNOWLEDGMENTS}

We are indebted to Joseph L. Applegate (FSU) and Timothy J. Bralower (Scripps Institution of Oceanography) for their helpful collaboration on taxonomic problems; Bralower also examined in detail samples from Core 603B-44 and reviewed an early draft of the manuscript. We also thank Drs. John C. Steinmetz (Marathon Oil Co.) and Peter H. Roth (University of Utah) for their official reviews of the draft manuscript and their helpful comments. We are also most grateful to Mr. Richard Pollastro (Oil and Gas Division, U.S. Geological Survey, Denver, Colorado) for arranging essential laboratory support. Professor Walter E. Forehand (FSU Classics Department) and Dr. Betty Serow kindly assisted in formulating names for new taxa. Ms. Kimberly A. Riddle and Gabriella W. Li printed the micrographs, which were taken by the first author, except for those in Plate 8, Figures 2 and 3, which were taken by T. J. Bralower. Mssrs. James R. Breza and Wuchang Wei helped prepare the manuscript, and Breza prepared all of the samples. Additional laboratory support was provided by $\mathrm{Na}$ tional Science Foundation Grant DPP-8414268 and a grant from the Amoco Foundation.

\section{REFERENCES}

Barnard, T., and Hay, W. W., 1971. On Jurassic coccoliths: a tentative zonation of the Jurassic of Southern England and Northern France. Ecolgae Geol. Helv., 67:563-597.
Black, M., 1971. Coccoliths of the Speeton Clay and Sutterby Marl. Proc. Yorkshire Geol. Soc., 38:381-424.

1972. British Lower Cretaceous coccoliths. I. Gault Clay. 1. Monogr. Palaeontogr. Soc. London, 126:1-48.

1973. British Lower Cretaceous coccoliths. I. Gault Clay. 2. Monogr. Palaeontogr. Soc. London, 127:49-112.

Bukry, D., 1970. Coccolith age determinations, Leg 2, Deep Sea Drilling Project. In Peterson, M. N. A., Edgar, N. T., et al., Init. Repts. $D S D P, 2$ : Washington (U.S. Govt. Printing Office), 349-355.

1981. Cenozoic coccoliths from the Deep Sea Drilling Project. In Warme, J. E., Douglas, R. G., and Winterer, E. L. (Eds.), The Deep Sea Drilling Project: A Decade of Progress: Tulsa (Soc. Econ. Paleontol. Mineral.), pp. 335-353.

Bukry, D., and Bramlette, M. N., 1969. Summary of coccolith biostratigraphy. In Ewing, M., Worzel, J. L., et al., Init. Repts. DSDP, 1: Washington (U.S. Govt. Printing Office), 667-687.

Bybell, L., and Gartner, S., 1972. Provincialism among mid-Eocene calcareous nannofossils. Micropaleontology, 18:319-336.

Covington, M., 1985. New morphologic information on Cretaceous nannofossils from the Niobrara Formation (Upper Cretaceous) of Kansas. Geology, 13:683-686.

Forchheimer, S., and Stradner, H., 1973. Scampanella, eine neue Gattung kretazischer Nannofossilien. Verh. Geol. B.-A., 2:285-289.

Gartner, S., 1977. Calcareous nannofossil biostratigraphy and revised zonation of the Pleistocene. Mar. Micropaleontol., 2:1-25.

, 1980. Calcareous nannofossils, Deep Sea Drilling Project Holes 417D, 418A, and 418B. In Donnelly, T., Francheteau, J., Bryan, W., Robinson, P., Flower, M., Salisbury, M., et al., Init. Repts. DSDP, 51, 52, 53, Pt. 2: Washington (U.S. Govt. Printing Office), 815-821.

Gorka, H., 1957. Les Coccolithophorides du Maestrichtien superieur de Pologne. Acta Palaeontol. Polonica., 2:235-284.

Hallam, A., 1984. Continental humid and arid zones during the Jurassic and Cretaceous. Palaeogeogr., Palaeoclimatol., Palaeoecol., 47:195-223.

1986. Role of climate in affecting Late Jurassic and Early Cretaceous sedimentation in the North Atlantic. In Summerhayes, C. P., and Shackleton, N. J. (Eds.), North Atlantic Palaeoceanography. Geol. Soc. London Spec. Paper,

Hattner, J. G., and Wise, S. W., 1980. Upper Cretaceous calcareous nannofossil biostratigraphy of South Carolina. S. C. Geol., 24: 41-117.

Hay, W. W., 1969. Preliminary dating by fossil calcareous nannoplankton, Deep Sea Drilling Project, Leg 1. In Ewing, M., and Worzel, J. L., et al., Init. Repts. DSDP, 1: Washington (U.S. Govt. Printing Office), 388-391.

1970. Calcareous nannofossils from cores recovered on Leg 4. In Bader, R. G., Gerard, R. D., et al., Init. Repts. DSDP, 4: Washington (U.S. Govt. Printing Office), 445-501.

Heck, S. E. van, 1979a. Bibliography and taxa of calcareous nannoplankton. Int. Nannoplankton Assoc. Newsl., 1:AB1-5, A1-12, B1-27.

, 1979b. Bibliography and taxa of calcareous nannoplankton. Int. Nannoplankton Assoc. Newsl., 1:AB VI, A13-28, B28-42.

1980a. Bibliography and taxa of calcareous nannoplankton. Int. Nannoplankton Assoc, Newsl., 2:5-34.

1980b. Bibliography and taxa of calcareous nannoplankton. Int. Nannoplankton Assoc. Newsl., 2:43-81.

, 1981a. Bibliography and taxa of calcareous nannoplankton. Int. Nannoplankton Assoc. Newsl., 3:4-41.

1981b. Bibliography and taxa of calcareous nannoplankton. Int. Nannoplankton Assoc. Newsl., 3:51-86.

1982a. Bibliography and taxa of calcareous nannoplankton. Int. Nannoplankton Assoc. Newsl., 4:7-50.

, 1982b. Bibliography and taxa of calcareous nannoplankton. Int. Nannoplankton Assoc Newsl., 4:65-96.

1983. Bibliography and taxa of calcareous nannoplankton Int. Nannoplankton Assoc. Newsl., 5:4-13.

Hill, M. E., 1976. Lower Cretaceous calcareous nannofossils from Texas and Oklahoma. Palaeontographica B., 156:103-179.

Jansa, L. F., Tucholke, B. E., Gradstein, F. M., and Sheridan, R. E., 1979. Mesozoic-Cenozoic sedimentary formations of the North American Basin; western North Atlantic. In Talwani, M., Hay, W. 
W., and Ryan, W. B. F. (Eds.), Deep Drilling Results in the Atlantic Ocean: Continental Margins and Paleoenvironment: Washington (Am. Geophys. Union), Maurice Ewing Series, 3:1-57.

Köthe, A., 1982. Kalkiges Nannoplankton aus dem Unter-Hauterivium bis Unter-Barremium der Tongrube Moorberg/Sarstedt (Unter-Kreide, NW-Deutschland). Mitt. Geol. Palaeontol. Inst. Univ. Hannover, 21:1-95.

Lancelot, Y., Winterer, E. L., et al., 1980. Init. Repts. DSDP, 50: Washington (U.S. Govt. Printing Office).

Leg 93 staff, 1983. The continental rise off North America. Nature, 305:386.

Loeblich, A. R., Jr., and Tappan, H., 1966. Annotated index and bibliography of the calcareous nannoplankton, I. Phycologia, 5:81-216. 1968. Annotated index and bibliography of the calcareous nannoplankton, II, J. Palaeontol., 42:584-598.

1969. Annotated index and bibliography of the calcareous nannoplankton, III. J. Paleontol, 43:568-588.

1970a. Annotated index and bibliography of the calcareous nannoplankton, V. J. Paleontol., 44:558-574.

$1970 \mathrm{~b}$. Annotated index and bibliography of the calcareous nannoplankton, V. Phycologia, 9:157-174.

1971. Annotated index and bibliography of the calcareous nannoplankton, VI. Phycologia, 10:315-339.

1973. Annotated index and bibliography of the calcareous nannoplankton, VII. J. Paleontol., 47:715-759.

Manivit, H., 1971. Les nannofossiles calcaires du Crétacé français (de l'Aptien au Danien). Essai de biozonation appuyée sur les stratotypes [Thèse] . Université de Paris.

Manivit, H., Perch-Nielsen, K., Prins, B., and Verbeek, J. W., 1977. Mid Cretaceous calcareous nannofossil biostratigraphy. Proc. $K$. Ned. Akad. Wet., Ser. B 80(3):169-181.

Martini, E., 1971. Standard Tertiary and Quaternary calcareous nannoplankton zonation. In Farinacci, A. (Ed.), Proc. II Plankt. Conf. Roma: (Edizioni Tecnoscienza), 2:739-785.

Okada, H., and Bukry, D., 1980. Supplementary modification and introduction of code numbers to the "low-latitude coccolith biostratigraphic zonation” (Bukry, 1973; 1975). Mar. Micropaleontol., 5: 321-325.

Okada, H., and Thierstein, H. R., 1979. Calcareous nannoplanktonLeg 43, Deep Sea Drilling Project. In Tucholke, B. E., and Vogt, P. R., et al., Init. Repts. DSDP, 43: Washington (U.S. Govt. Printing Office), 507-573.

Perch-Nielsen, K., 1979. Calcareous nannofossils from the Cretaceous between the North Sea and the Mediterranean. In Wiedman, J. (Ed.), Aspekte der Kreide Europas: Stuttgart (Schweizerbart), Int. Union Geol. Sci. Ser. A, 6:223-272.

1985. Mesozoic calcareous nannofossils. In Bolli, H. M., Saunders, J. B., and Perch-Nielsen, K. (Eds.), Plankton Stratigraphy: Cambridge (Cambridge University Press), pp. 329-426.

Prins, B., 1969. Evolution and stratigraphy of coccolithinids from the Lower and Middle Lias. In Brönnimann, P., and Renz, H. H. (Eds.), Proc. First Int. Conf. Planktonic Microfossils, Geneva, 2: 547-558.

Roth, P. H., 1973. Calcareous nannofossils-Leg 17, Deep Sea Drilling Project. In Winterer, E. L., Ewing, J. I., et al., Init. Repts. $D S D P, 17$ : Washington (U.S. Govt. Printing Office), 695-795.

1978. Cretaceous nannoplankton biostratigraphy and oceanography of the northwestern Atlantic Ocean. In Benson, W. E., Sheridan, R. E., et al., Init. Repts. DSDP, 44: Washington (U.S. Govt. Printing Office), 731-759.

, 1983. Jurassic and Lower Cretaceous calcareous nannofossils in the western North Atlantic (Site 534): biostratigraphy, preservation, and some observations on biogeography and paleoceanography. In Sheridan, R. E., Gradstein, F. M., et al., Init. Repts. DSDP, 76: Washington (U.S. Govt. Printing Office), 587-621.

Roth, P. H., and Krumbach, K. R., 1986. Middle Cretaceous calcareous nannofossil biogeography and preservation in the Atlantic and Indian oceans: implications for paleoceanography. Mar. Micropaleontol., 10:235-266.

Roth, P. H., and Thierstein, H. R., 1972. Calcareous nannoplankton: Leg 14 of the Deep Sea Drilling Project. In Hayes, D. E., Pimm, A. C., et al., Init. Repts. DSDP, 14: Washington (U.S. Govt. Printing Office), 421-486.

Schlanger, S. O., and Douglas, R. G., 1974. The pelagic-ooze-chalklimestone transition and its implication for marine stratigraphy. In
Hsü, K. J., and Jenkyns, H. (Eds.), Pelagic Sediments on Land and Under the Sea: Oxford (Blackwell), Internat. Assoc. Sedimentol. Spec. Publ., 1:117-148.

Sheridan, R. E., Gradstein, F. M., et al., 1983. Init. Repts. DSDP, 76: Washington (U.S. Govt. Printing Office).

Siesser, W. G., 1980. Calcareous nannofossils: Legs 51 and 52 of the Deep Sea Drilling Project. In Donnelly, T. Francheteau, J., Bryan, W., Robinson, P., Flower, M., Salisbury, M. et al., Init. Repts. DSDP , 51, 52, 53, Pt. 2: Washington (U.S. Govt. Printing Office), 823-845.

Stafleu, F. A., Demoulin, V., Greuter, W., Heipko, P., Linczevski, A., McVaugh, R., Meikle, R. D., Rollins, R. C., Ross, R., Schopf, J. M., and Voss, E. G., 1978. International Code of Botanical Nomenclature: Utrecht, Netherlands (Bohn, Scheltema and Holkema).

Steinmetz, J. C., 1984a. Bibliography and taxa of calcareous nannoplankton-III. Int. Nannoplankton Assoc. Newsl., 6:6-37. 1984b. Bibliography and taxa of calcareous nannoplankton-IV. Int. Nannoplankton Assoc. Newsl., 6:55-81.

1985. Bibliography and taxa of calcareous nannoplanktonV. Int. Nannoplankton Assoc. Newsl., 7:5-28.

Stover, L. E., 1966. Cretaceous coccoliths and associated nannofossils from France and The Netherlands. Micropaleontology, 12:133-167.

Thierstein, H. R., 1971. Tentative Lower Cretaceous calcareous nannoplankton zonation. Eclogae Geol. Helv., 64:459-488.

1973. Lower Cretaceous calcareous nannoplankton zonation. Abh. Geol. Bundesanst. (Wein), 29:1-52.

1975. Calcareous nannoplankton biostratigraphy at the Jurassic-Cretaceous boundary. Colloque sur la limite Jurassique-Crétacé. Mem. Bur. Rech. Geol. Minieres, 86:84-94.

1976. Mesozoic calcareous nannoplankton biostratigraphy of Marine sediments. Mar. Micropaleontol., 1:325-362.

Tucholke, B. E., and Vogt, P. R., 1979. Western North Atlantic: sedimentary evolution and aspects of tectonic history. In Tucholke, B. E., Vogt, P. R., et al., Init. Repts. DSDP, 43: Washington (U.S. Govt. Printing Office), 791-825.

van Hinte, J. E., 1976. A Cretaceous time scale. Am. Assoc. Petrol. Geol. Bull., 60:498-516.

Wiegand, G. E., 1984. Jurassic nannofossils from the northwest African margin, Deep Sea Drilling Project Leg 79. In Hinz, K., Winterer, E. L., et al., Init. Repts. DSDP, 79: Washington (U.S. Govt. Printing Office), 657-670.

Wilcoxon, J. A., 1972. Upper Jurassic-Lower Cretaceous calcareous nannoplankton from the western North Atlantic Basin. In Hollister, C. D., Ewing, J. I., et al., Init. Repts. DSDP, 11: Washington (U.S. Govt. Printing Office), 221-225.

Wind, F. H., and Čepek, P., 1979. Lower Cretaceous calcareous nannoplankton from DSDP Hole 397A (Northwest African Margin). In von Rad, U., and Ryan, W. B. F., et al., Init. Repts. DSDP, 47, Pt. 1: Washington (U.S. Govt. Printing Office), 269-492.

Wise, S. W., 1977. Mesozoic and Cenozoic calcareous nannofossils recovered by DSDP Leg 36 drilling on the Falkland Plateau, Southwest Atlantic Sector of the Southern Ocean. In Barker, P. F., Dalziel, I. W. D., et al., Init. Repts. DSDP, 36: Washington (U.S. Govt. Printing Office), 269-491.

1983. Mesozoic and Cenozoic calcareous nannofossils recovered by Deep Sea Drilling Project Leg 71 in the Falkland Plateau region, Southwest Atlantic Ocean. In Ludwig, W. J., Krasheninnikov, V. A., et al., Init. Repts. DSDP, 71: Washington (U.S. Govt. Printing Office), 481-550.

Wise, S. W., and Kelts, K. R., 1972. Inferred diagenetic history of a weakly silicified deep sea chalk. Trans. Gulf Coast Assoc. Geol. Soc., 22:177-203.

Wise, S. W., and Wind, F., 1977. Mesozoic and Cenozoic calcareous nannofossils recovered by DSDP Leg 36 drilling on the Falkland Plateau, Southwest Atlantic sector of the Southern Ocean. In Barker, P. F., Dalziel, I. W. D., et al., Init. Repts. DSDP, 36: Washington (U.S. Govt. Printing Office), 269-492.

Worsley, T. R., 1971. Calcareous nannofossil zonation of Upper Jurassic and Lower Cretaceous sediments from the western Atlantic. In Farinacci, A. (Ed.), Proc. Second Planktonic Conf. Roma 1970: Rome (Edizioni Techonscienza) 2:1301-1321.

Date of Initial Receipt: 6 August 1985

Date of Acceptance: 24 June 1986 


\section{APPENDIX A}

Calcareous Nannofossils Considered in This Chapter (in alphabetical order of generic epithets)

Assipetra infracretacea (Thierstein) Roth, 1973

Axopodorhabdus dietzmannii (Reinhardt) Wind and Wise, 1983

Braarudosphaera discula Bramlette and Riedel, 1954

Braarudosphaera regularis Black, 1973

Calcicalathina oblongata (Worsley) Thierstein, 1971

Chiastozygus litterarius (Gorka) Manivit, 1971

Chiastozygus striatus Black, 1971

Chiastozygus tenuis Black, 1971

Conusphaera mexicana Trejo, 1969

Corollithion achylosum (Stover) Thierstein, 1971

Corollithion acutum Thierstein in Roth and Thierstein, 1972

Corollithion ellipticum Bukry, 1969

Cretarhabdus conicus Bramlette and Martini, 1964

Cretarhabdus crenulatus (Bramlette and Martini) (Grun in Grun and Allemann, 1975

Cretarhabdus? delicatus Applegate, Covington, and Wise, n. sp.

Cretarhabdus sp. cf. C. multiformis Black, 1971

Cretarhabdus surirellus (Deflandre in Deflandre and Fert) Reinhardt emend. Thierstein, 1971

Cruciellipsis cuvillieri (Manivit) Thierstein, 1971

Cyclagelosphaera deflandrei (Manivit) Roth, 1973

Cyclagelosphaera margerelii Noël, 1965

Diadorhombus rectus Worsley, 1971

Diazomatolithus lehmanii Noël, 1965

Diloma placinum Wind and Cepek, 1979

Diloma primitiva (Worsley) Wind and Cepek, 1979

Discorhabdus biradiatus (Worsley) Thierstein ex Applegate, Covington, and Wise

Discorhabdus ignotus (Gorka) Perch-Nielsen, 1968

Eiffellithus sp. 1

Eiffellithus sp. 2

Ethmorhabdus? hauterivianus (Black) Applegate, Covington, and Wise, n. comb.

Flabellites biforaminis Thierstein, 1973

Glaukolithus diplogrammus (Deflandre in Deflandre and Fert) Reinhardt, 1964

Grantarhabdus coronadventis (Reinhardt) Grün in Grün and Allemann

Grantarhabdus meddii Black, 1971

Haqius circumradiatus (Stover) Roth, 1978

Hayesites irregularis (Thierstein) Applegate, Covington, and Wise, n. comb.

Lithraphidites alatus alatus Thierstein in Roth and Thierstein, 1972

Lithraphidites alatus magnus Covington and Wise, $\mathrm{n}$. ssp.

Lithraphidites carniolensis Deflandre, 1963

Manivitella sp. cf. M. pecten Black, 1973

Manivitella pemmatoidea (Deflandre in Manivit) Thierstein, 1971

Micrantholithus hoschulzii (Reinhardt) Thierstein, 1971

Micrantholithus obtusus Stradner, 1963

Microstaurus conus (Worsley) Wind and Čepek, 1979

Microstaurus chiastius (Worsley) Grün in Grün and Allemann, 1975

Nannoconus bermudezii Brönnimann, 1955

Nannoconus colomii (de Lapparent) Kamptner, 1938

Nannoconus dolomiticus Cita and Pasquare, 1959

Nannoconus globulus Brönnimann, 1955

Nannoconus grandis Deres and Acheriteguy, 1980

Nannoconus sp. cf. N. kamptneri Brönnimann, 1955

Nannoconus steinmannii Kamptner, 1931

Octopodorhabdus plethotretus Wind and Čepek ex Applegate, Covington, and Wise

Percivalia fenestrata (Worsley) Wise, 1983

Perissocyclus sp. cf. P. noeliae Black, 1971, emend. Wind and Čepek, 1979

Pickelhaube furtiva (Roth) Applegate, Covington, and Wise, n. gen., emend., n. comb.

Polypodorhabdus madingleyensis Black, 1968

Reinhardtites? sp. cf. R. elegans (Gartner) Wise, 1983

"Rhabdolekiscus" parallelus Wind and Cepek, 1979
Rhabdophidites aquitanicus (Manivit) Applegate, Covington, and Wise, n. comb.

Rhagodiscus angustus (Stradner) Reinhardt, 1971

Rhagodiscus asper (Stradner) Reinhardt, 1967

Rhagodiscus infinitus (Worsley) Applegate, Covington, and Wise, n. comb.

Rhagodiscus splendens (Deflandre) Verbeek, 1977

Rhagodiscus swinnertonii (Black) Applegate, Covington, and Wise, n. comb.

Rucinolithus terebrodentarius Applegate, Bralower, Covington, and Wise, n. sp.

Rucinolithus wise Threrstein, 1971

Speetonia colligata Black, 1971

Stephanolithion laffittei Noël, 1956

Tegumentum stradneri Thierstein, in Roth and Thierstein, 1972

Tetrapodorhabdus coptensis Black, 1971

Tubodiscus verenae Thierstein, 1973

Vekshinella strandneri Rood, Hay, and Barnard, 1971

Watznauerea barnesae (Black in Black and Barnes) Perch-Nielsen, 1968

Watznaueria biporta Bukry, 1969

Watznaueria fasciata Wind and Čepek, 1979

Watznaueria britannica (Stradner) Reinhardt, 1964

Zebrashapka vanhintei Covington and Wise, n. gen., n. sp.

Zeugrhabdotus embergeri (Noël) Perch-Nielsen, 1984

Zeugrhabdotus erectus (Deflandre) Manivit, 1971

Zeugrhabdotus? pseudoangustus Bralower, Applegate, Covington, and Wise, n. sp.

Genus et sp. indet. 1

Genus et sp. indet. 2

\section{APPENDIX B}

Calcareous Nannofossils Considered in This Chapter (in alphabetical order of specific epithets)

Corollithion achylosum (Stover) Thierstein, 1971

Corollithion acutum Thierstein in Roth and Thierstein, 1972

Lithraphidites alatus alatus Thierstein in Roth and Thierstein, 1972

Lithraphidites alatus magnus Covington and Wise, n. ssp.

Rhagodiscus angustus (Stradner) Reinhardt, 1971

Rhabdophidites aquitanicus (Manivit) Applegate, Covington, and Wise, n. comb.

Rhagodiscus asper (Stradner) Reinhardt, 1967

Watznauerea barnesae (Black in Black and Barnes) Perch-Nielsen, 1968

Nannoconus bermudezii Brönnimann, 1955

Watznueria biporta Bukry, 1969

Flabellites biforaminis Thierstein, 1973

Discorhabdus biradiatus (Worsley) Thierstein ex Applegate, Covington, and Wise

Watznaueria britannica (Stradner) Reinhardt, 1964

Lithraphidites carniolensis Deflandre, 1963

Microstaurus chiastius (Worsley) Grün in Grün and Allemann, 1975

Haqius circumradiatus (Stover) Roth, 1978

Speetonia colligata Black, 1971

Nannoconus colomii (de Lapparent) Kamptner, 1938

Cretarhabdus conicus Bramlette and Martini, 1964

Microstaurus conus (Worsley) Wind and Cepek, 1979

Tetrapodorhabdus coptensis Black, 1971

Grantarhabdus coronadventis (Reinhardt) Grün in Grün and Allemann

Cretarhabdus crenulatus (Bramlette and Martini) Grün in Grün and Allemann, 1975

Cruciellipsis cuvillieri (Manivit) Thierstein, 1971

Cyclagelosphaera deflandrei (Manivit) Roth, 1973

Cretarhabdus? delicatus Applegate, Covington, and Wise, n. sp.

Axopodorhabdus dietzmannii (Reinhardt) Wind and Wise, 1983

Glaukolithus diplogrammus (Deflandre in Deflandre and Fert) Reinhardt, 1964

Braarudosphaera discula Bramlette and Riedel, 1954

Nannoconus dolomiticus Cita and Pasquare, 1959

Reinhardtites? sp, cf. R. elegans (Gartner) Wise 1983

Corollithion ellipticum Bukry, 1969

Zeugrhadotus embergeri (Noël) Perch-Nielsen, 1984 
Zeugrhabdotus erectus (Deflandre) Manivit, 1971

Watznaueria fasciata Wind and Cepek, 1979

Percivalia fenestrata (Worsley) Wise, 1983

Pickelhaube furtiva (Roth) Applegate, Covington, and Wise, n. gen., emend., n. comb.

Nannoconus globulus Brönnimann, 1955

Nannoconus grandis Deres and Acheriteguy, 1980

Ethmorhabdus? hauterivianus (Black) Applegate, Covington, and Wise, n. comb.

Micrantholithus hoschulzii (Reinhardt) Thierstein, 1971

Discorhabdus ignotus (Gorka) Perch-Nielsen, 1968

Rhagodiscus infinitus (Worsley) Applegate, Covington, and Wise, $\mathrm{n}$. comb.

Assipetra infracretacea (Thierstein) Roth, 1973

Hayesites irregularis (Thierstein) Applegate, Covington, and Wise, $\mathrm{n}$. comb.

Nannoconus sp. cf. N. kamptneri Brönnimann, 1955

Stephanolithion laffittei Noël, 1956

Diazomatolithus lehmanii Noël, 1965

Chiastozygus litterarius (Gorka) Manivit, 1971

Polypodorhabdus madingleyensis Black, 1968

Cyclagelosphaera margerelii Noël, 1965

Grantarhabdus meddii Black, 1971

Conusphaera mexicana Trejo, 1969

Cretarhabdus sp. cf. C. multiformis Black, 1971

Perissocyclus sp. cf. P. noeliae Black, 1971, emend. Wind and Čepek, 1979

Calcicalathina oblongata (Worsley) Thierstein, 1971

Micrantholithus obtusus Stradner, 1963
"Rhabdolekiscus" parallelus Wind and Čepek, 1979

Manivitella sp. cf. M. pecten Black, 1973

Manivitella pemmatoidea (Deflandre in Manivit) Thierstein, 1971

Diloma placinum Wind and Čepek, 1979

Octopodorhabdus plethotretus Wind and Čepek ex Applegate, Covington, and Wise

Diloma primitiva (Worsley) Wind and Čepek, 1979

Zeugrhabdotus? pseudoangustus Bralower, Applegate, Covington, and Wise, n. sp.

Diadorhombus rectus Worsley, 1971

Braarudosphaera regularis Black, 1973

Eiffellithus sp. 1

Eiffellithus sp. 2

Rhagodicus splendens (Deflandre) Verbeek, 1977

Nannoconus steinmannii Kamptner, 1931

Tegumentum stradneri Thierstein in Roth and Thierstein, 1972

Vekshinella straderi Rood, Hay, and Barnard, 1971

Chiastozygus striatus Black, 1971

Cretarhabdus surirellus (Deflandre in Deflandre and Fert) Reinhardt emend. Thierstein, 1971

Rhagodiscus swinnertonii (Black) Applegate, Covington, and Wise, n. comb.

Chiastozygus tenuis Black, 1971

Rucinolithus terebrodentarius Applegate, Bralower, Covington, and Wise, n. sp.

Zebrashapka vanhintei Covington and Wise, n. gen., n. sp.

Tubodiscus verenae Thierstein, 1973

Rucinolithus wisei Thierstein, 1971

Genus et sp. indet. 1 

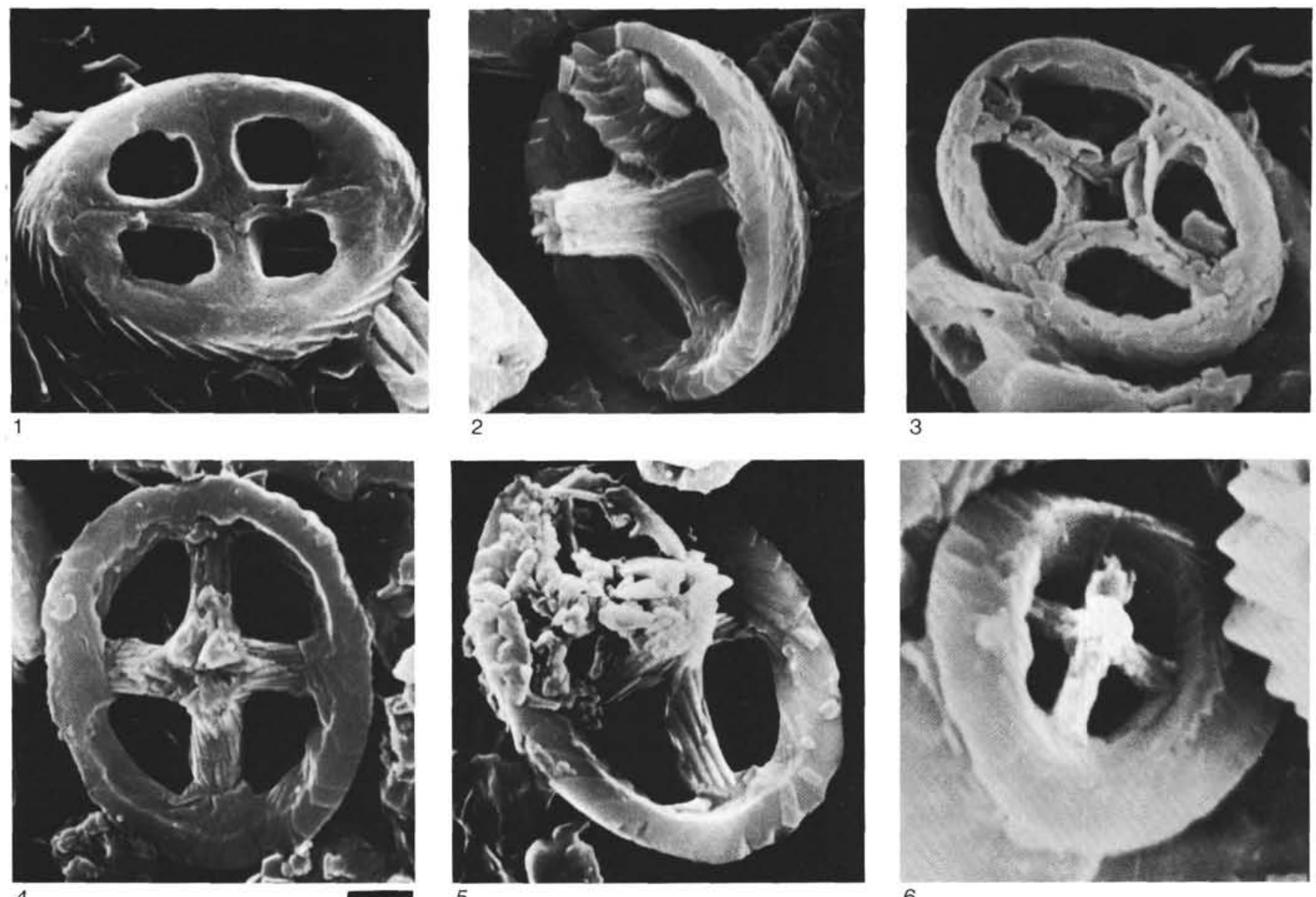

3
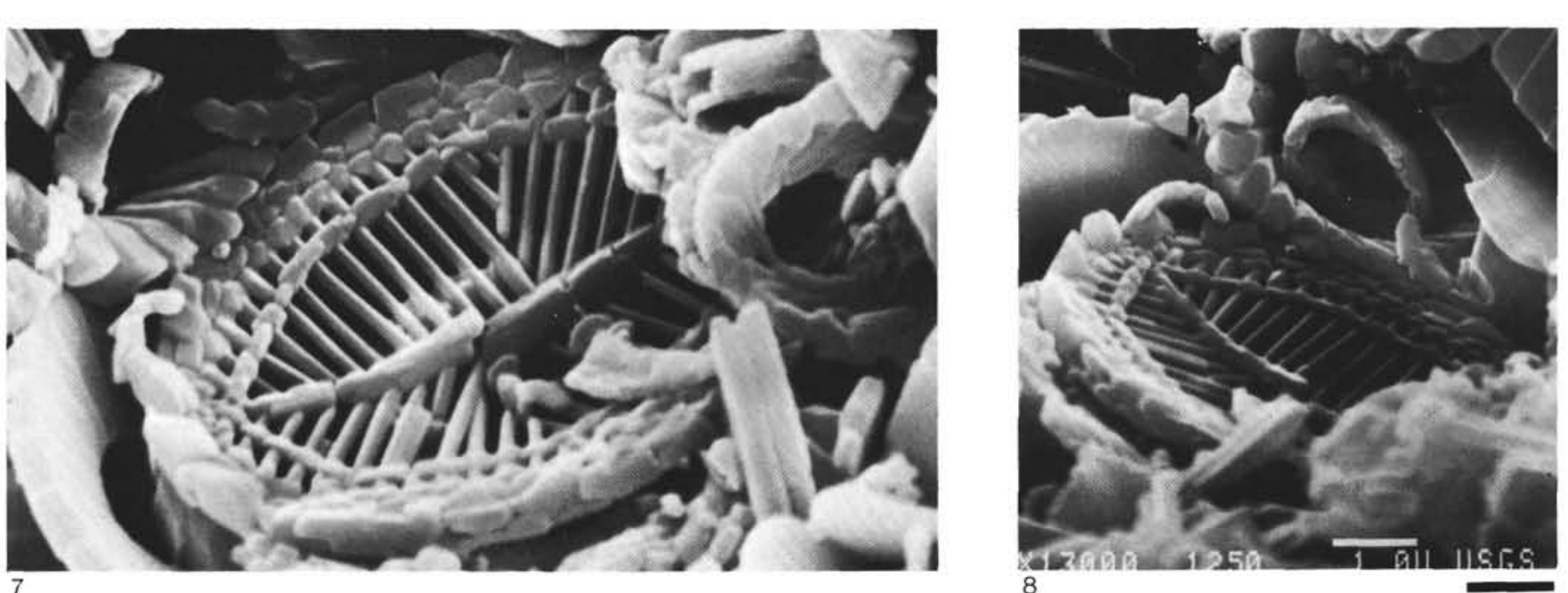

Plate 1. Ahmuellerellaceae, Coccolithaceae, and Arkhangelskiellaceae. 1-5. Vekshinella stradneri Rood, Hay, and Barnard, (1) P, $\times 11,000$, Sample 603B-60-1, $109 \mathrm{~cm}$; (2-5) Sample 603B-44-1, $113 \mathrm{~cm}(2, \mathrm{D}, \times 8000 ; 3, \mathrm{P}, \times 15,000 ; 4, \mathrm{D}, \times 8500 ; 5, \mathrm{D}, \times 10,000)$. 6. Cruciplacolithus hayi Black, 1973, D, $\times 13,000$, Sample 603B-44-1, $113 \mathrm{~cm}$. 7, 8. Diloma placinum Wind and Cepek, P, Sample 603B-76-2, 148 cm, (7) $\times 13,000$; (8) same specimen, $\times 9000$.

All illustrations on the plates are scanning electron micrographs unless noted otherwise in the captions. The abbreviations $\mathrm{P}, \mathrm{D}$, and $\mathrm{L}$ denote proximal, distal, and lateral views, respectively. The abbreviations $\mathrm{Pol}$ and $\mathrm{Ph}$ denote cross-polarized and phase contrast. 

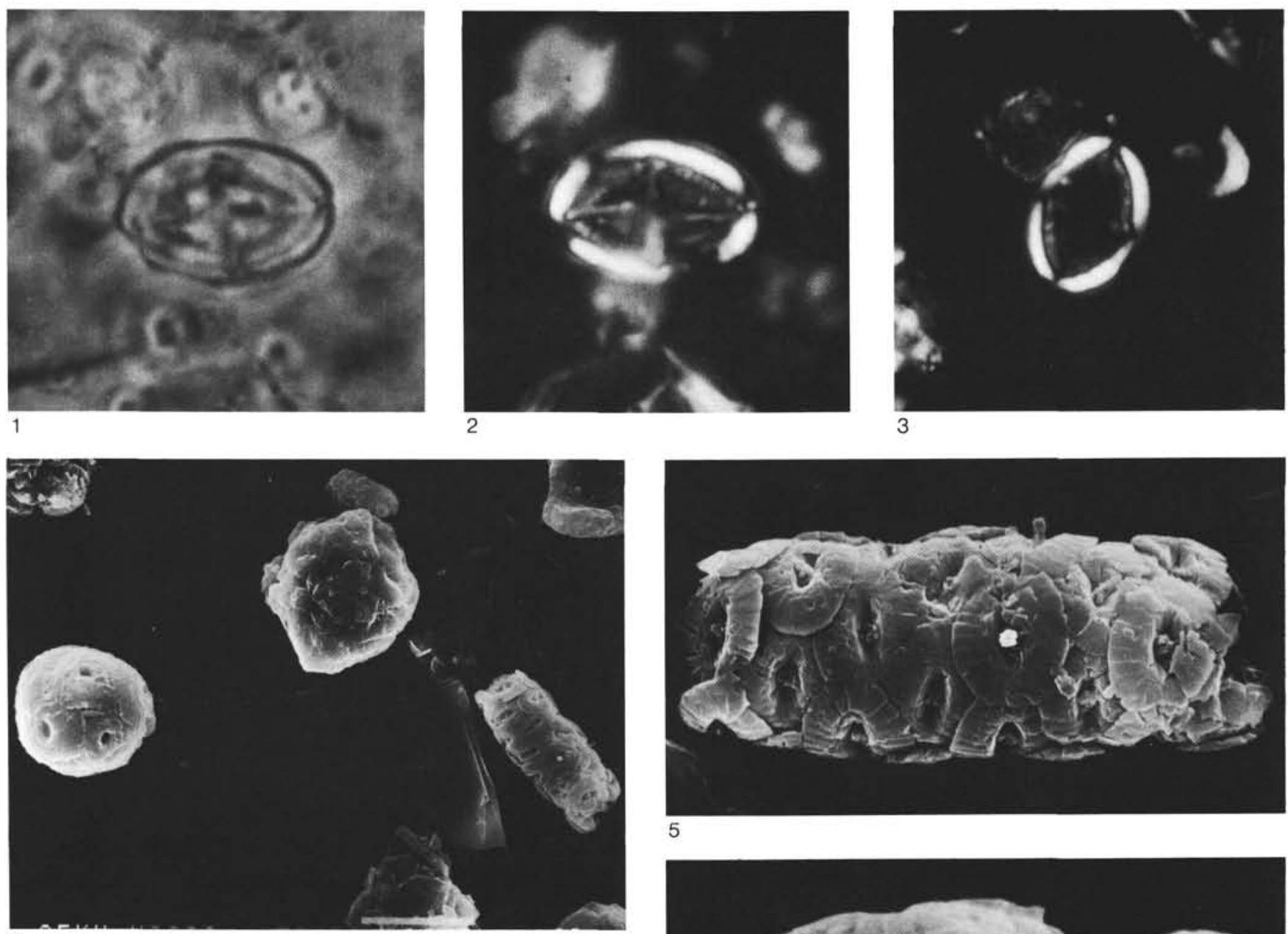
4

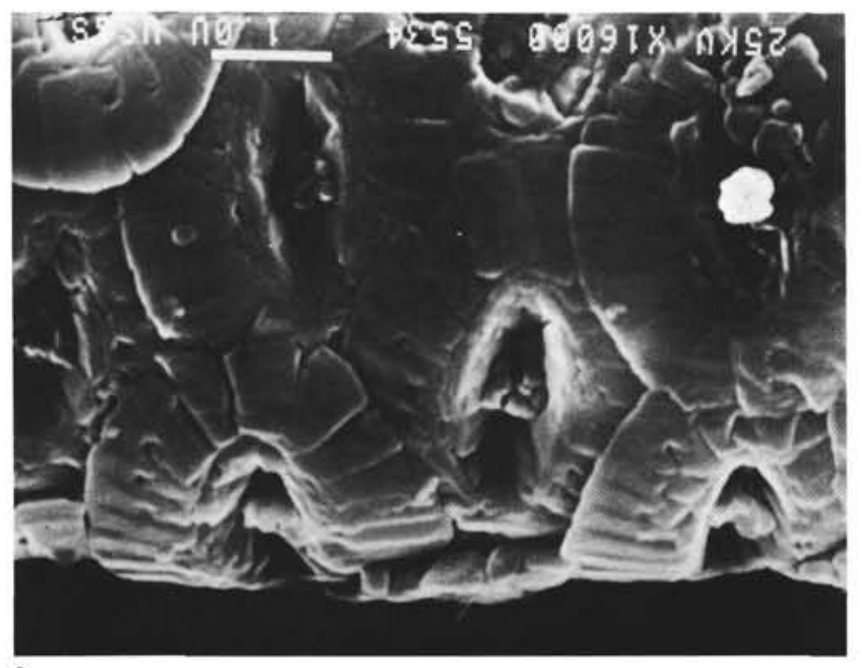

6

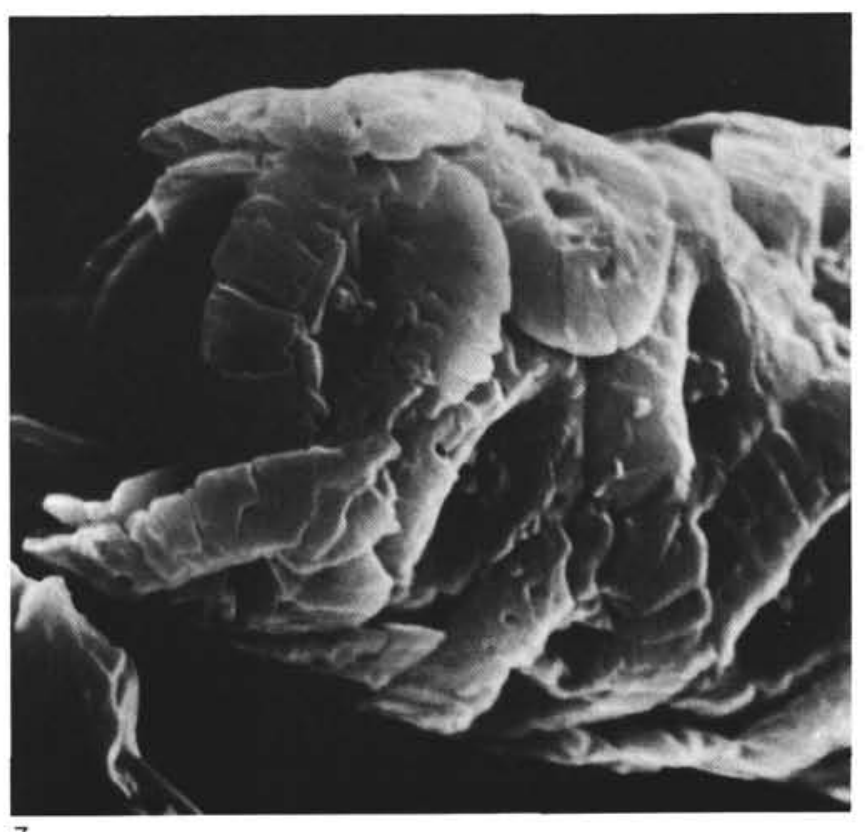

7

Plate 2. Arkhangelskiellaceae and Biscutaceae. 1-3. Diloma placinum Wind and Čepek, $\times 3800$, Sample $603 \mathrm{~B}-54, \mathrm{CC},(1) \mathrm{Ph}$; (2) Pol; (3) Pol. 4-7. Biscutum sp. 1, Sample 603B-55-1, $100 \mathrm{~cm},(4) \times 1500$, coccocylinder (right) and Watznaueria barnesae (Black) Perch-Nielsen coccosphere (left); (5) $\times 5000 ;(6) \times 12,000 ;(7) \times 10,5000$, end view. 


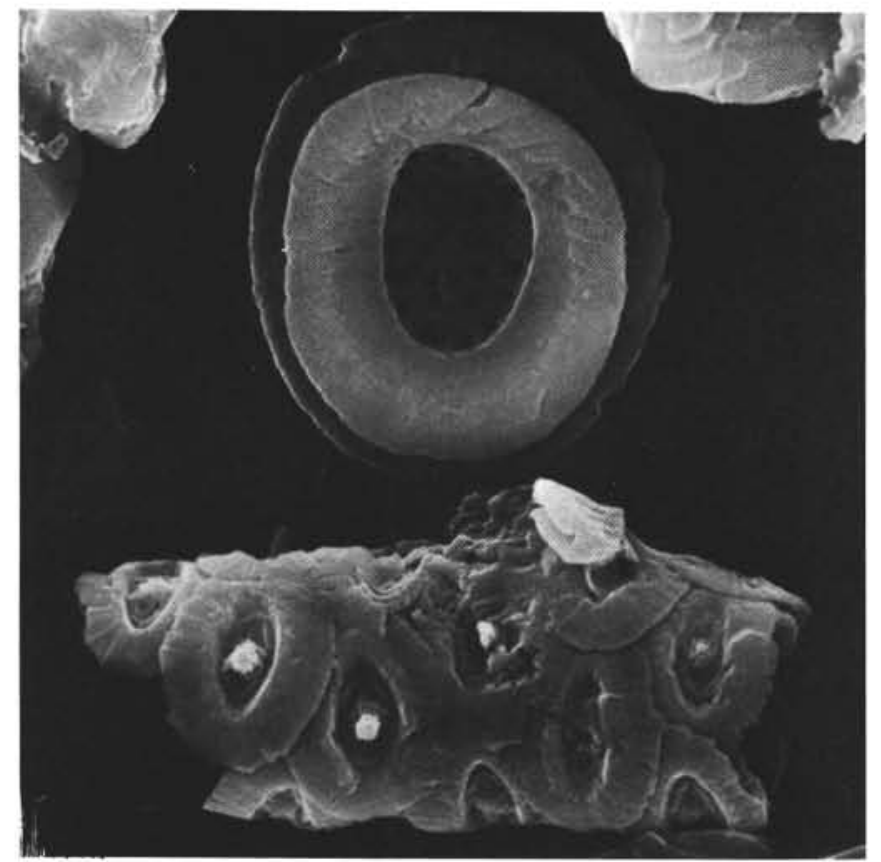

1

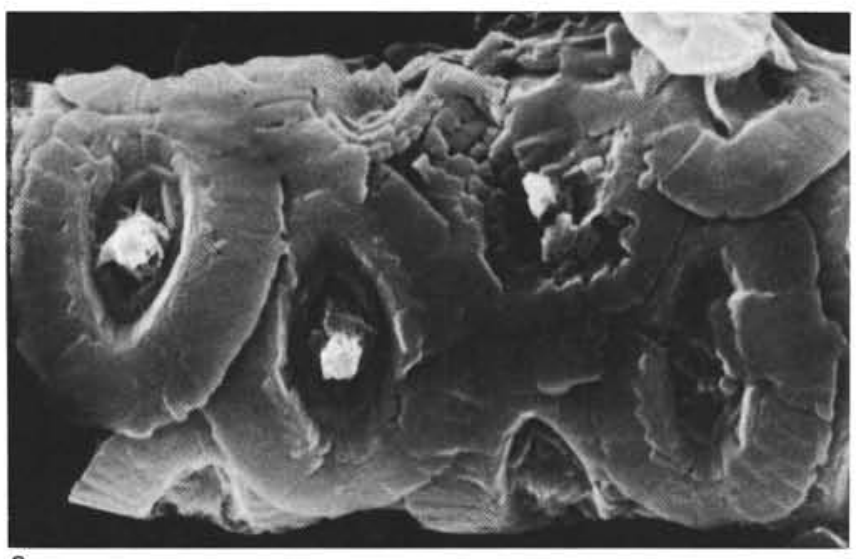

2

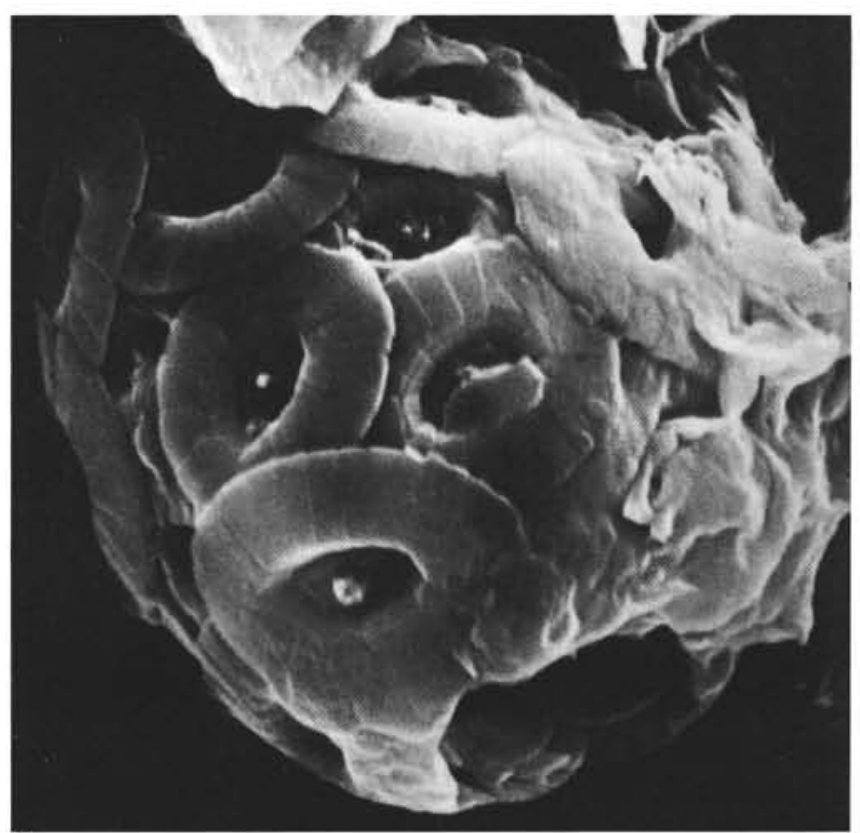

3

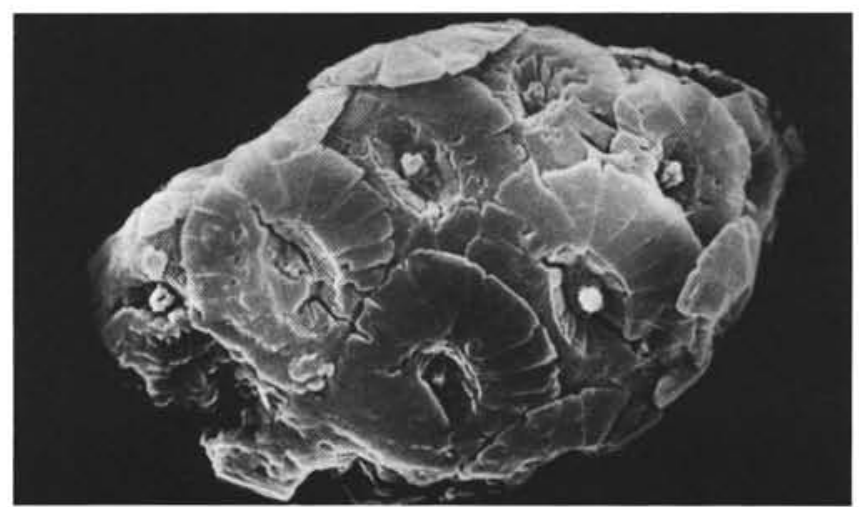

5

Plate 3. Biscutaceae. 1, 2. Biscutum sp. 1, coccocylinder, Sample $603 \mathrm{~B}-44-1,113 \mathrm{~cm},(1) \times 5500$; $(2) \times 10,000$. 3-5. Biscutum sp. 2, oval "coccospheres," (3) $\times 10,500$, Sample 603B-44,CC; (4) $\times 6000$, Sample 603B-76-2, $48 \mathrm{~cm}$; (5) $\times 7000$, Sample $603 \mathrm{~B}-55-1,100 \mathrm{~cm}$. 

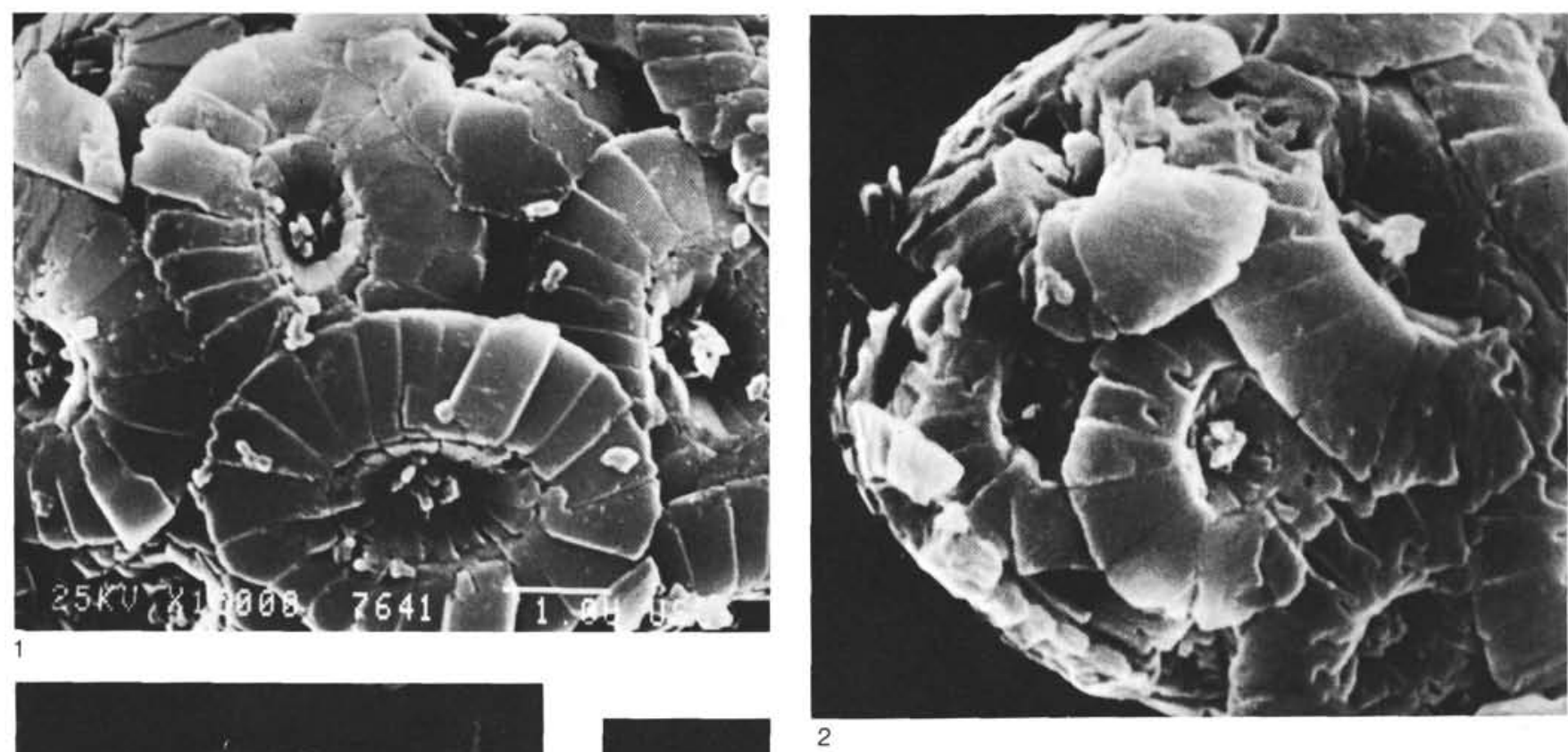

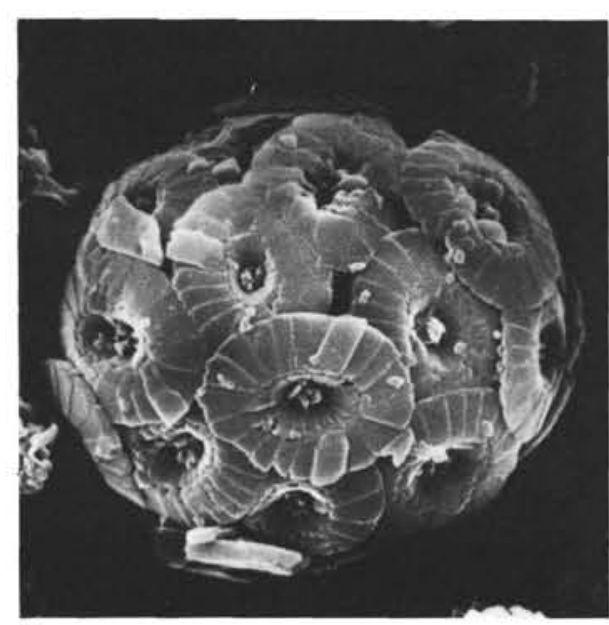

3

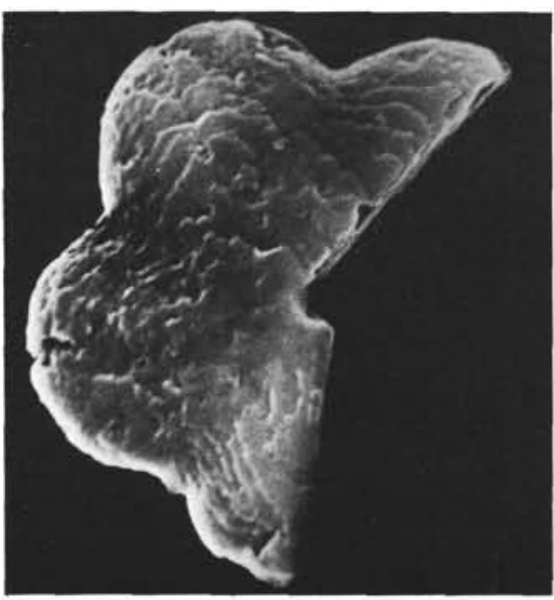

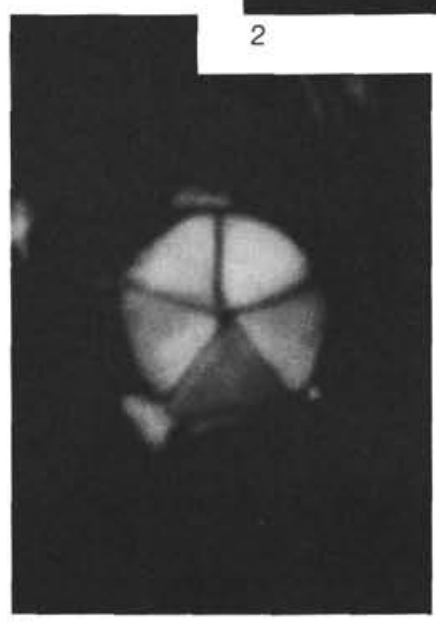

4

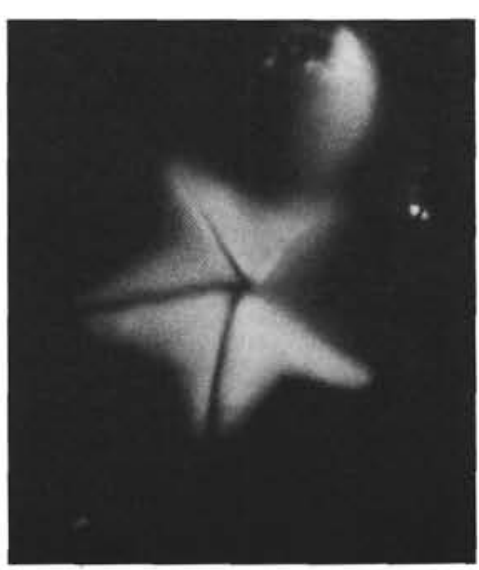

7

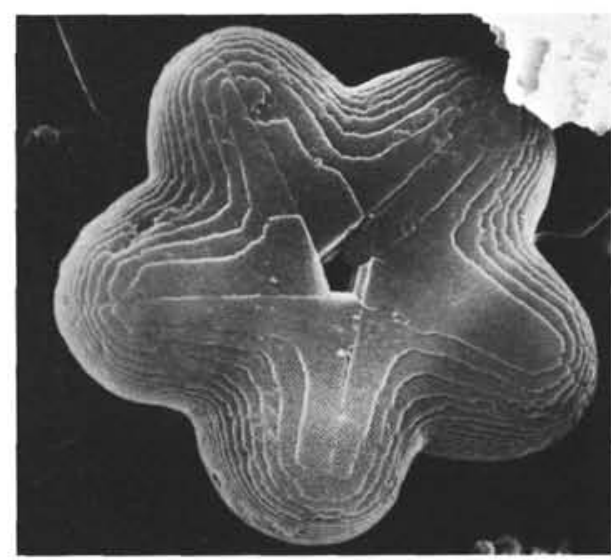

5

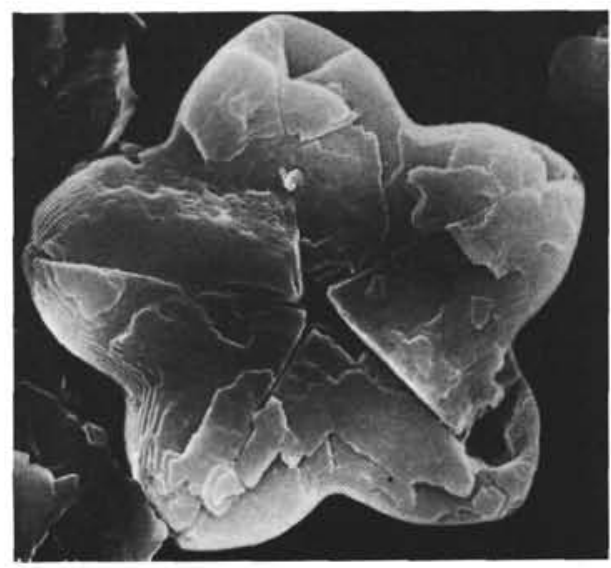

Plate 4. Biscutaceae and Braarudosphaeraceae. 1-3. Biscutum sp., (1) $\times 12,000$, Sample $603 \mathrm{~B}-76-2,48 \mathrm{~cm}$; (3) same specimen, $\times 5000$; (2) $\times 14,000$, Sample 603B-55-2, $100 \mathrm{~cm}$. 4. Braarudsphaera discula Bramlette and Riedel, Pol, $\times 2750$, Sample 603B-55,CC. 5-8. Micrantholithus obtusus Stradner, (5) P?, $\times 5500$, Sample 603B-44,CC; (6) D?, $\times 7000$, Sample 603B-57-2, $131 \mathrm{~cm} ;(7,8)$ Sample 603B-60-1, 109 cm (7, Pol, $\times 3000 ; 8, \mathrm{D} ?, \times 4500)$. 


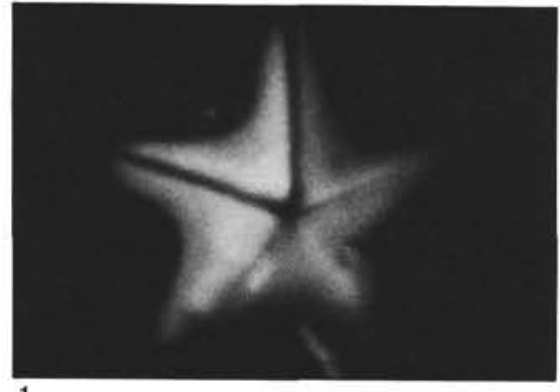

1

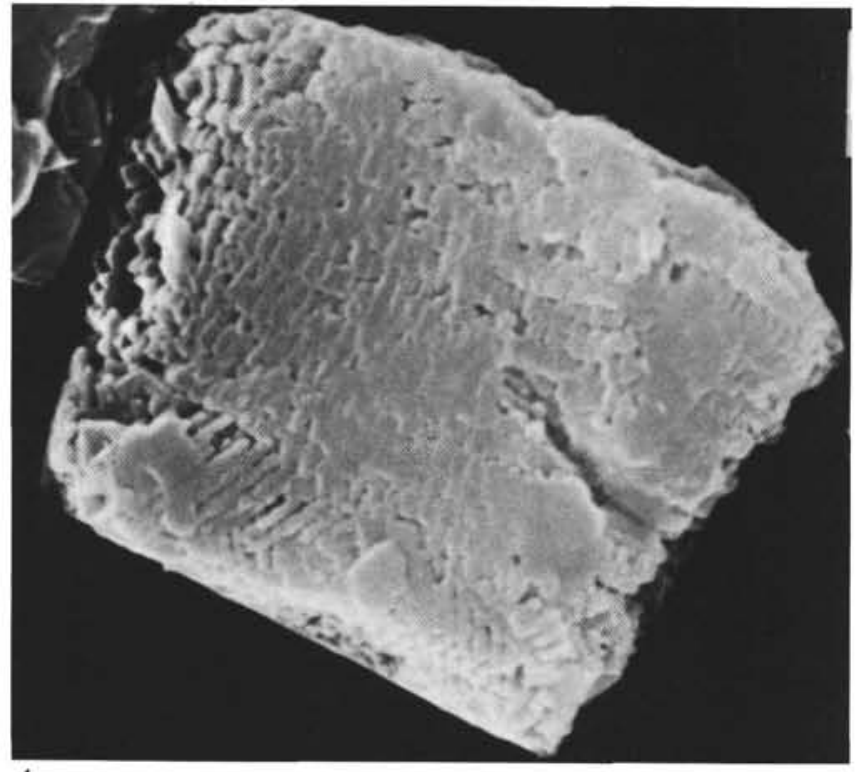

4

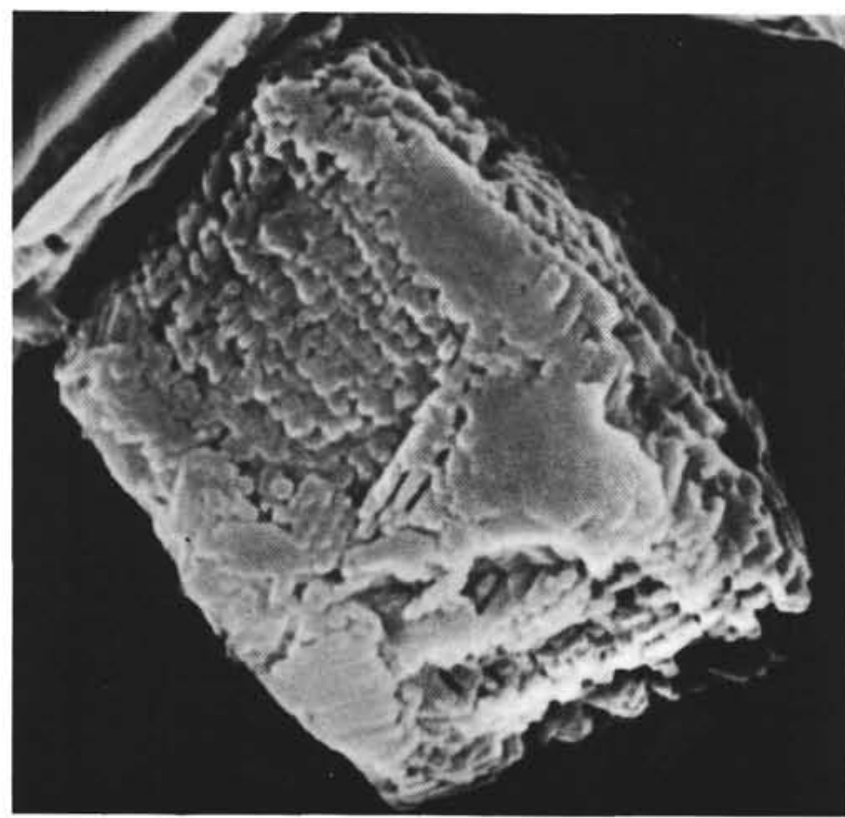

6
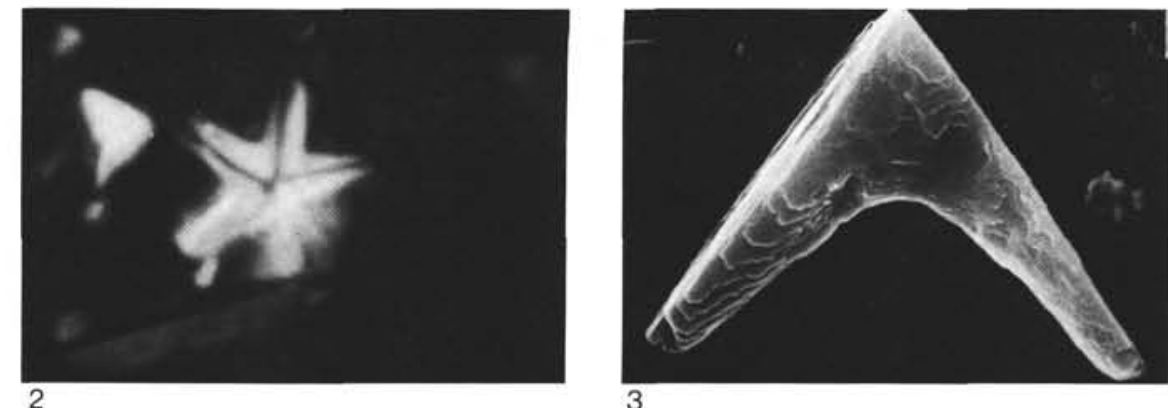

3

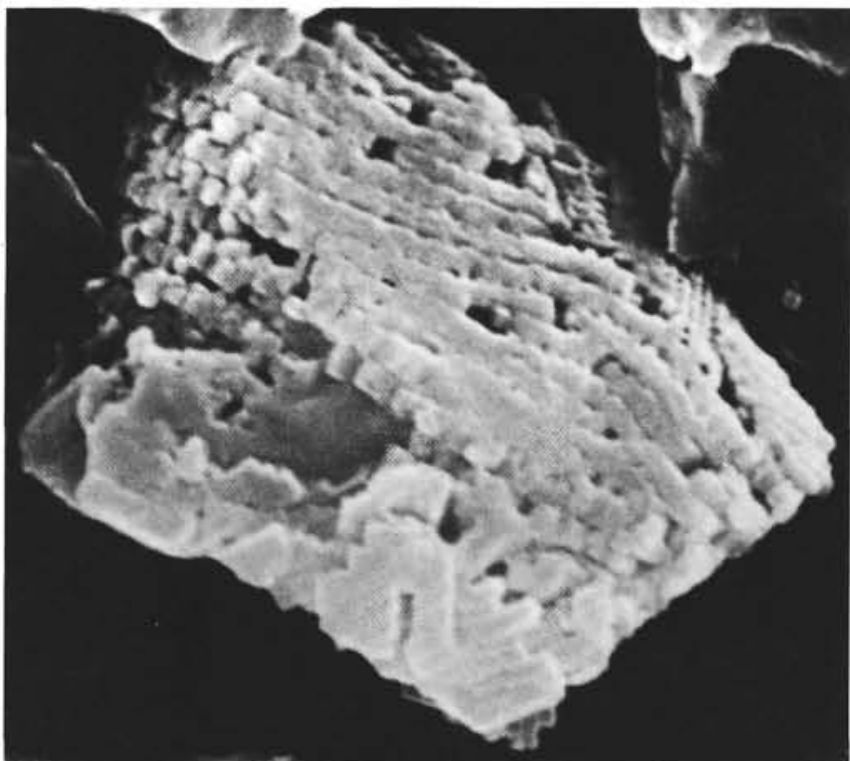

5

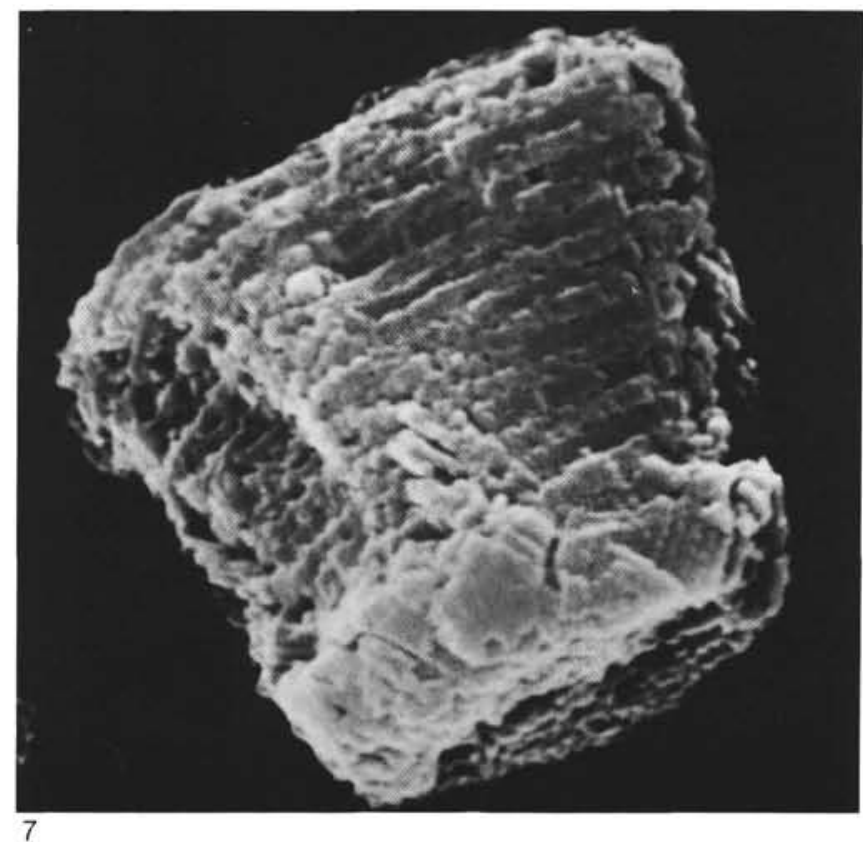

Plate 5. Braarudosphaeraceae and Calyptrosphaeraceae. 1. Micrantholithus obtusus Stradner, Pol, $\times 3500$, Sample 603B-46-2, 142 cm. 2, 3. Micrantholithus sp., Sample 603B-60-1, $109 \mathrm{~cm},(2)$ Pol, $\times 3000$, (3) D?, $\times 6000$. 4-7. Zebrashapka vanhintei Covington and Wise, n. gen., n. sp., (4-6) Sample 603B-57-2, $113 \mathrm{~cm}$ (4, paratype, L, $\times 13,000 ; 5$, paratype, L, $\times 16,000$; 6, holotype [same specimen as Plate 6, Fig. 3], L, $\times 13,500$ ); (7) paratype, DL, $\times 13,000$, Sample $603 \mathrm{~B}-60-1,109 \mathrm{~cm}$. 

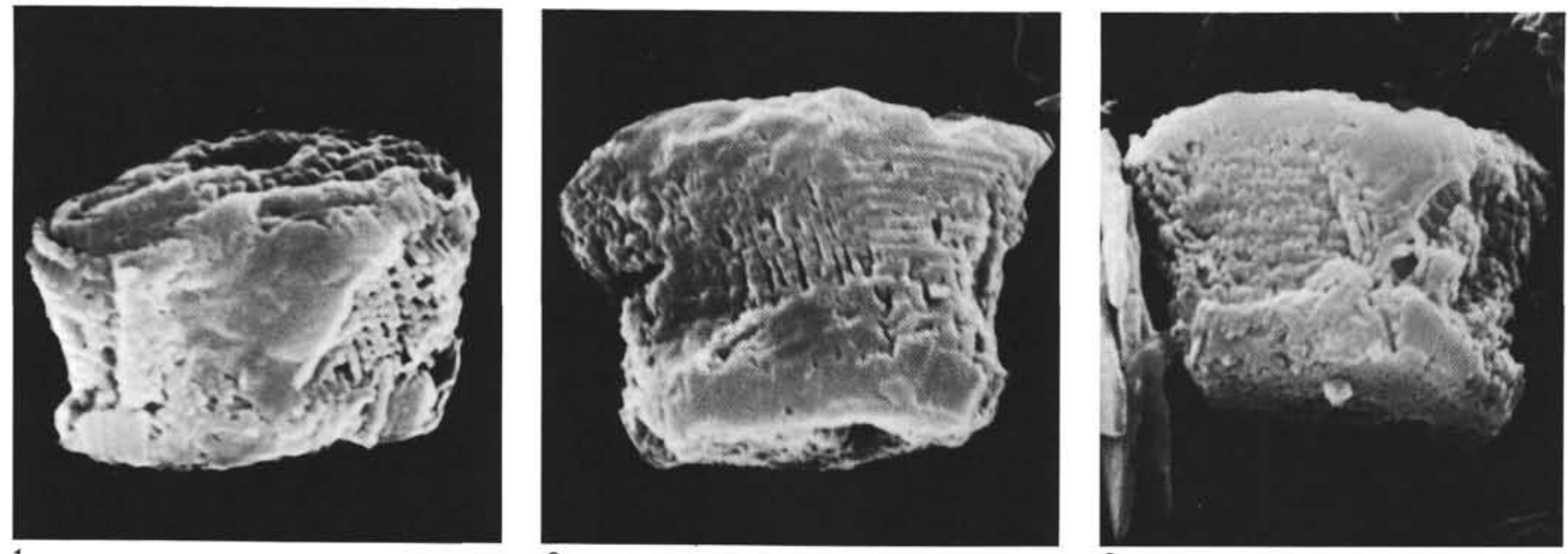

2

3
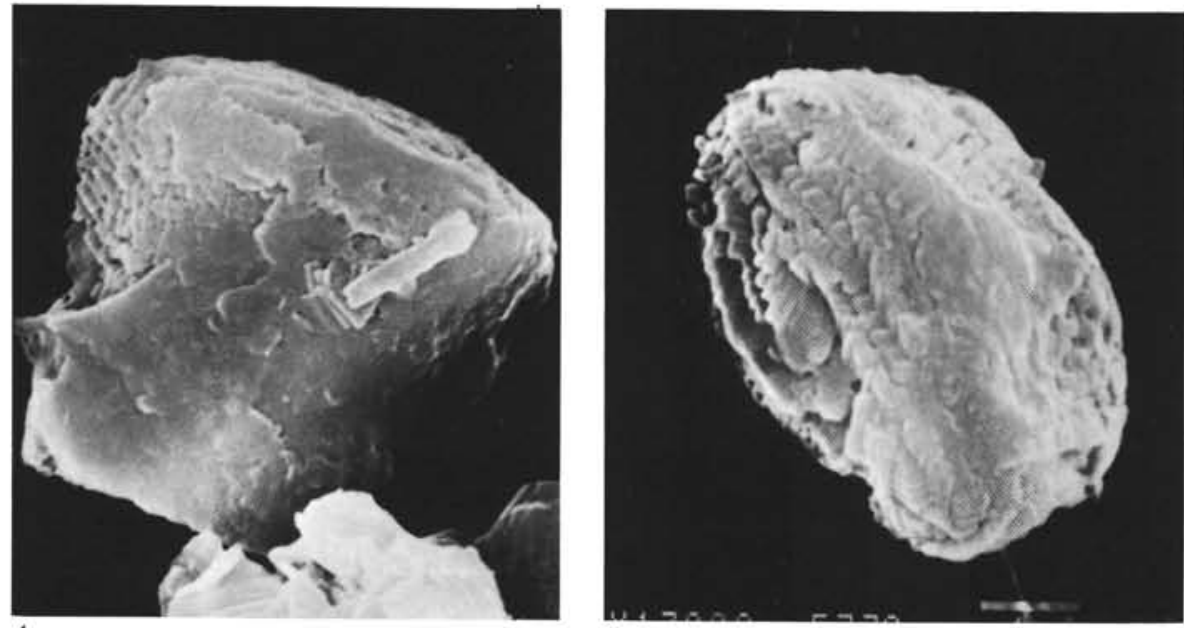

5
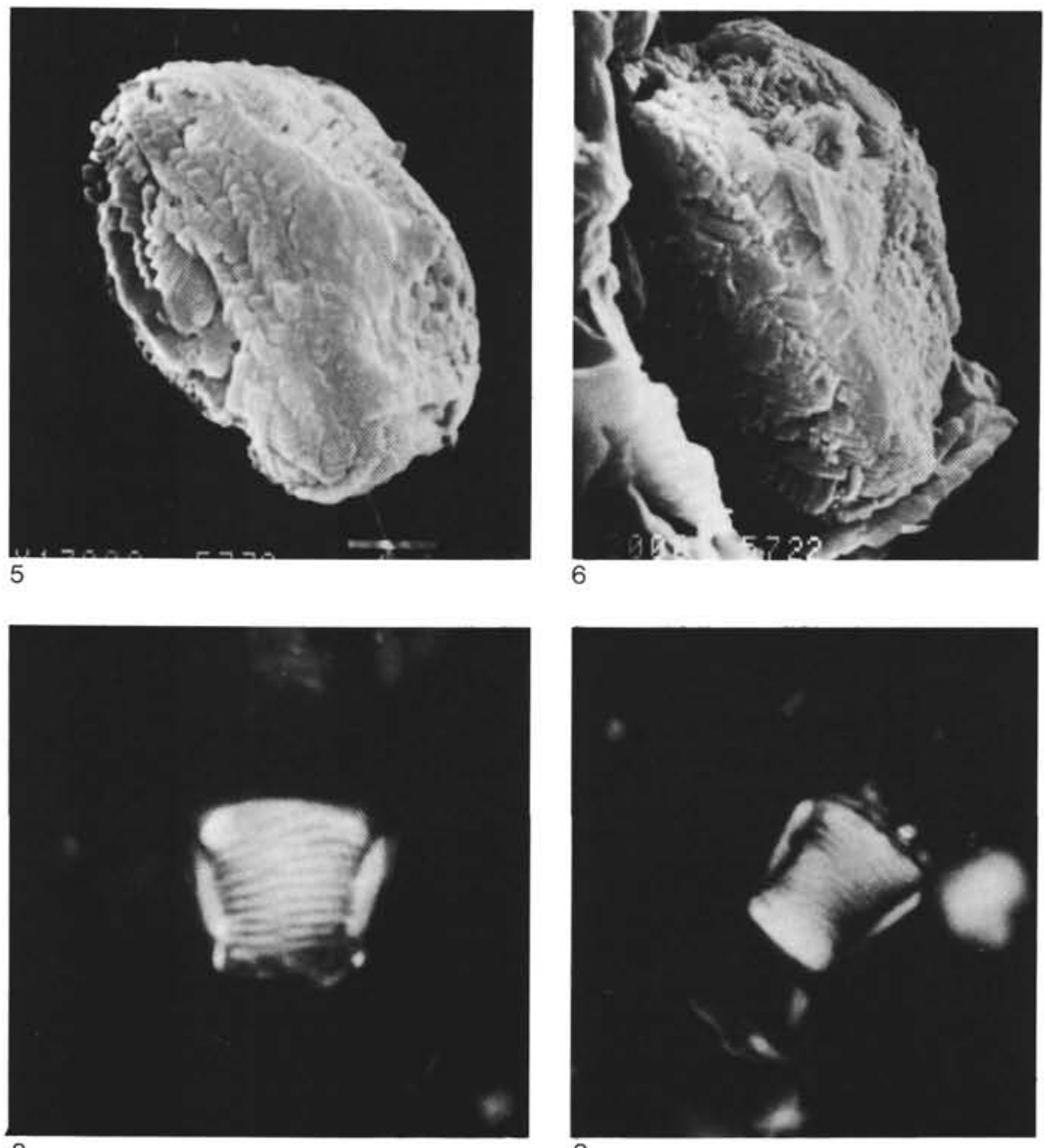

6

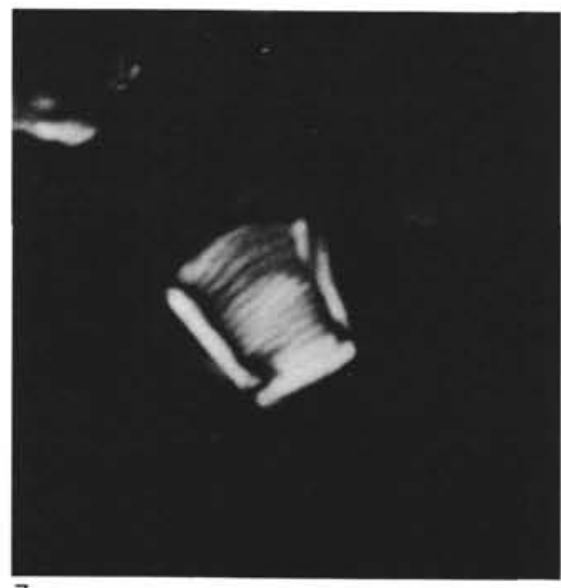

8

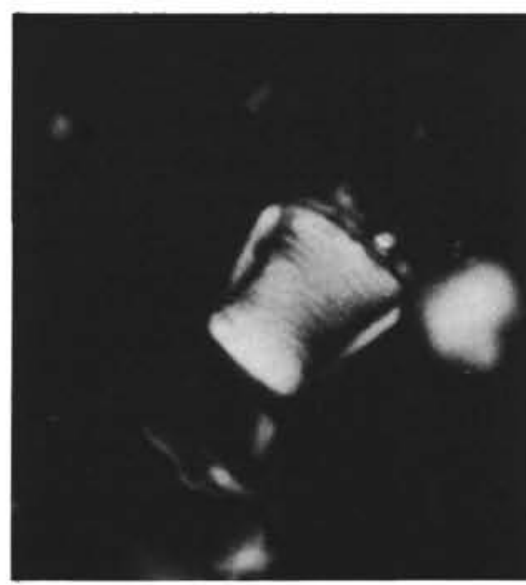

Plate 6. Calyptrosphaeraceae. 1-9. Zebrashapka vanhintei Covington and Wise, n. gen., n. sp., (1-5) Sample 603B-57-2, 131 cm, (1, paratype, L, $\times 10,500 ; 2$, paratype, L, $\times 10,000 ; 3$, holotype [same specimen as Plate 5, Fig. 6], L, $\times 8500 ; 4$, paratype, L, $\times 9000 ; 5$, paratype, PL, $\times 10,500)$; (6-9) Sample 603B-55,CC, paratypes (6, PL, $\times 9000 ; 7$, Pol, L, $\times 2750 ; 8$, Pol, L, $\times 3000 ; 9$, Pol, L, $\times 3000)$. 


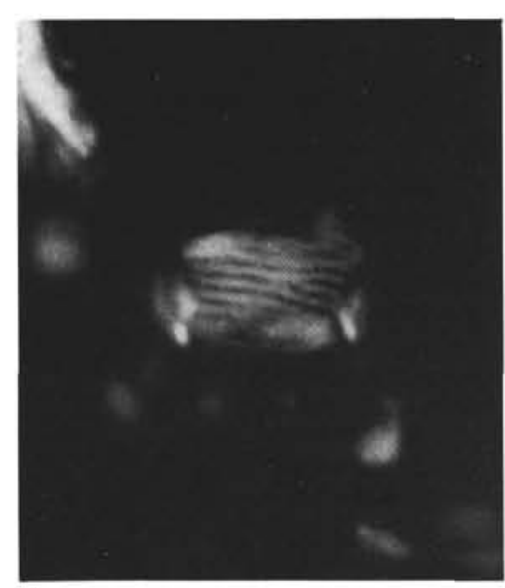

1

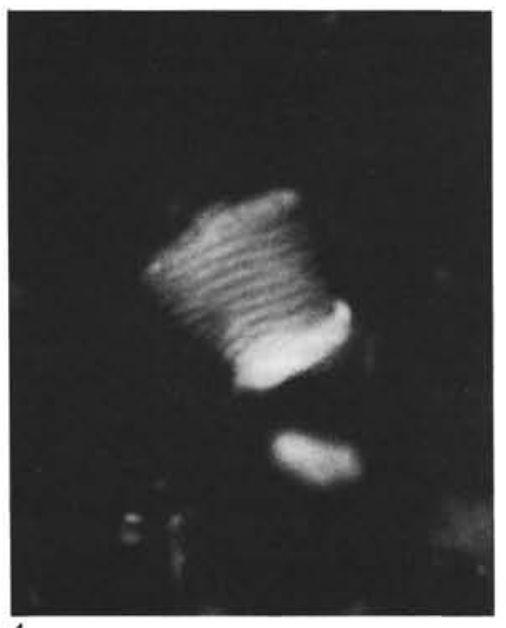

4

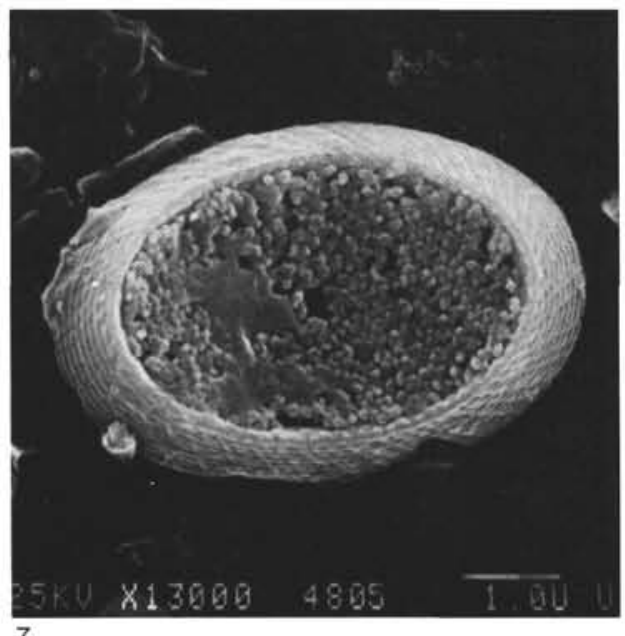

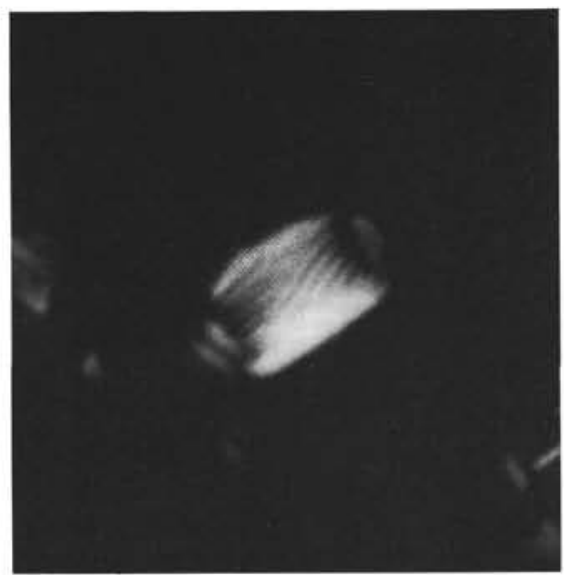

2

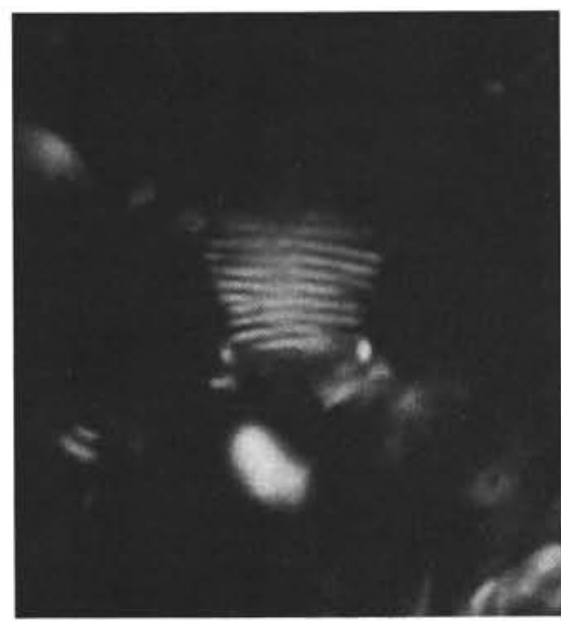

5

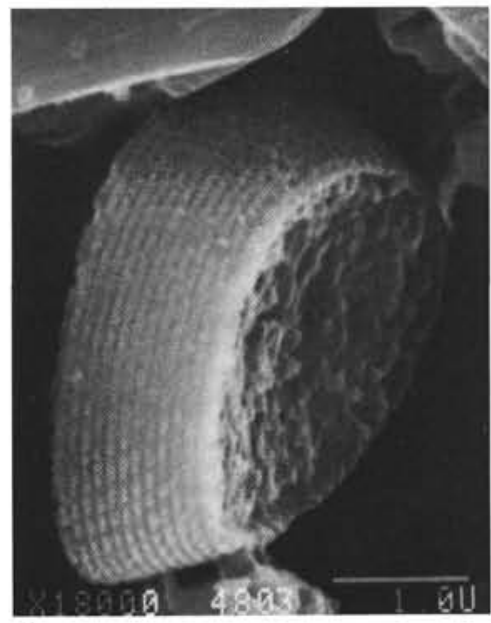

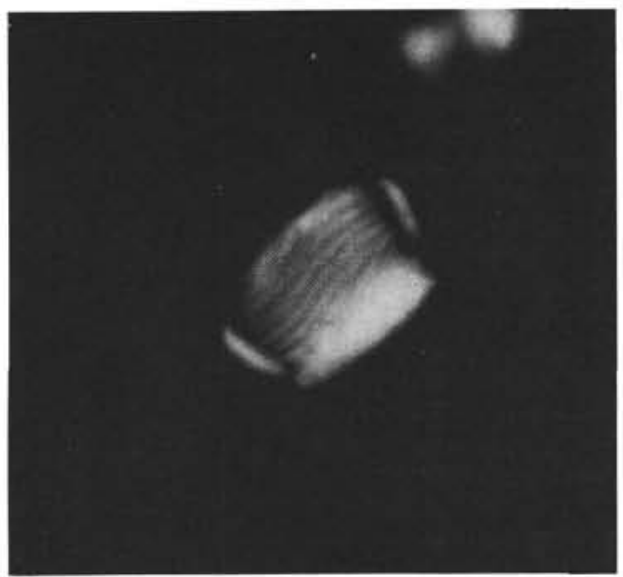

3

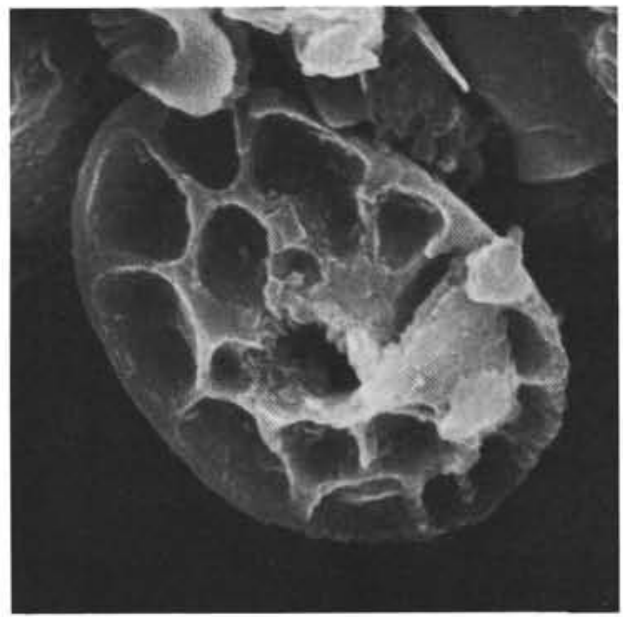

6

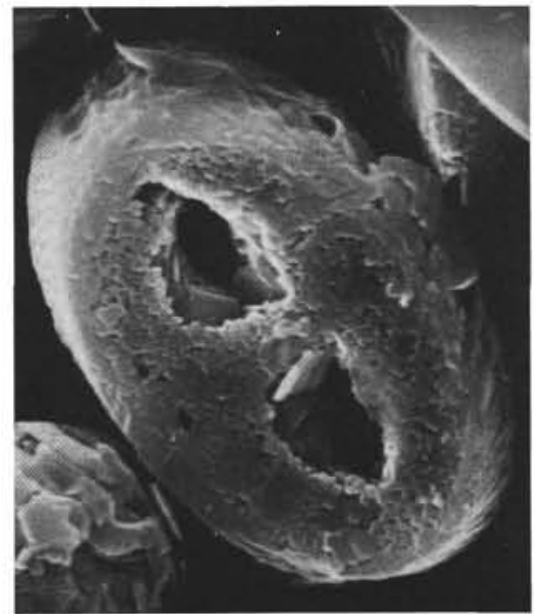

Plate 7. Calyptrosphaeraceae and Rhagodiscacae. 1-5. Zebrashapka vanhintei Covington and Wise, n. sp., paratypes, Sample 603B-55,CC, Pol, (1) $\times 2500$; (2) $\times 3500$; (3) L, $\times 3500$; (4) $\times 2500$; (5) $\times 3250$. 6-8. Rhagodiscus asper/splendens (Stradner) Reinhardt, Sample $603 \mathrm{~B}-48-1$, 113 $\mathrm{cm},(6) \mathrm{D}, \times 8000 ;(7) \mathrm{P}, \times 10,000 ;(8) \mathrm{L}, \times 12,000$. 9. Rhagodiscus infinitis (Worsley) Applegate, Covington, and Wise, $\mathrm{P}, \times 6500$, Sample $603 \mathrm{~B}-44-1,113 \mathrm{~cm}$. 


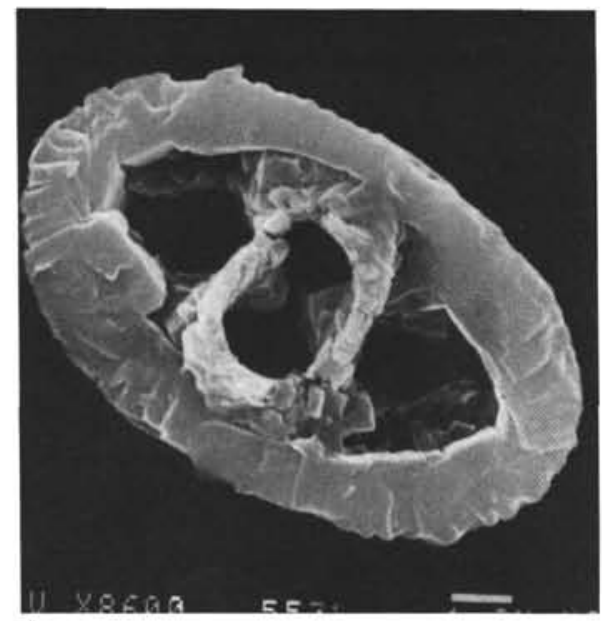

1

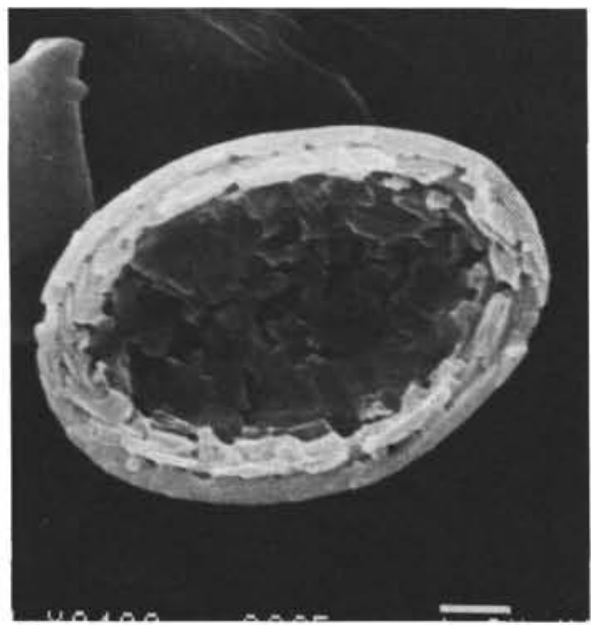

5

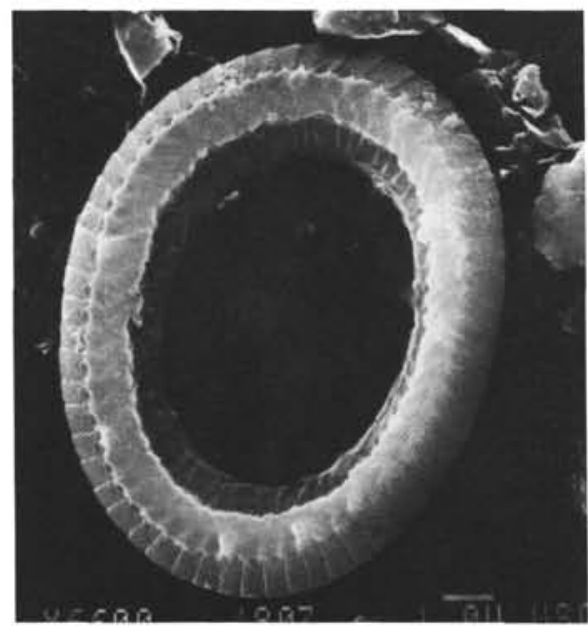

8

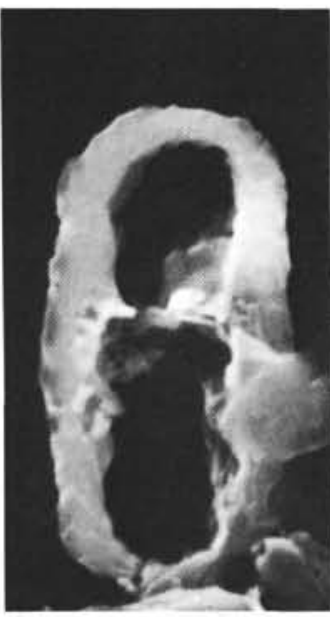

2
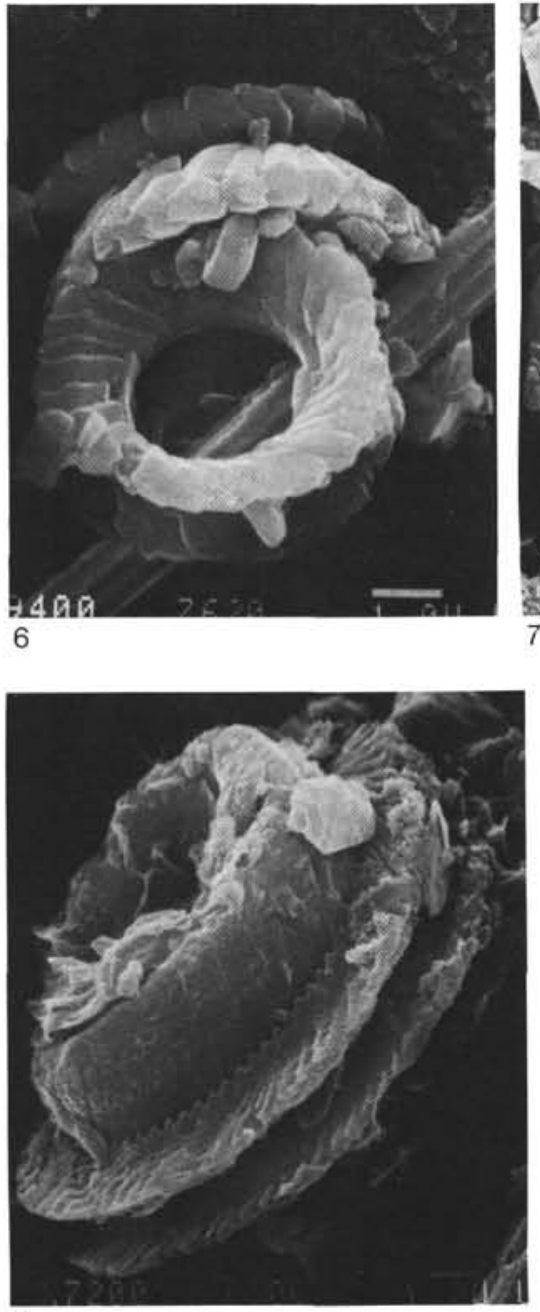

9
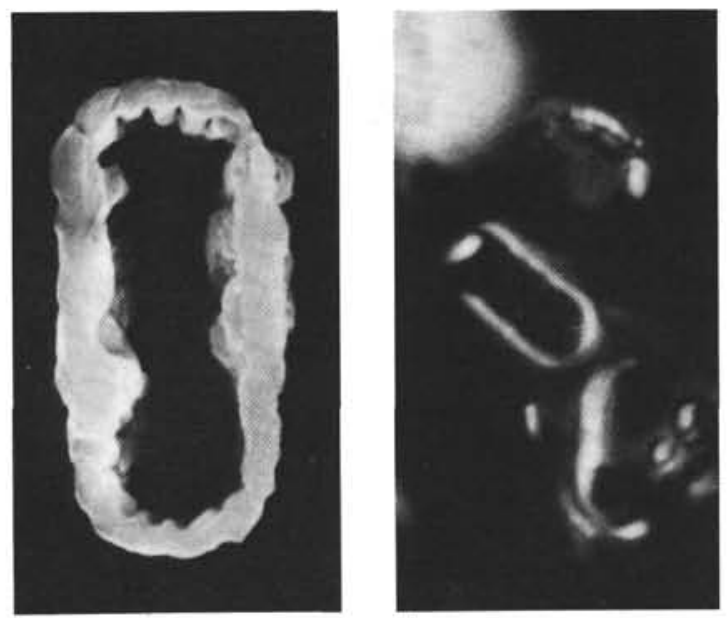

4
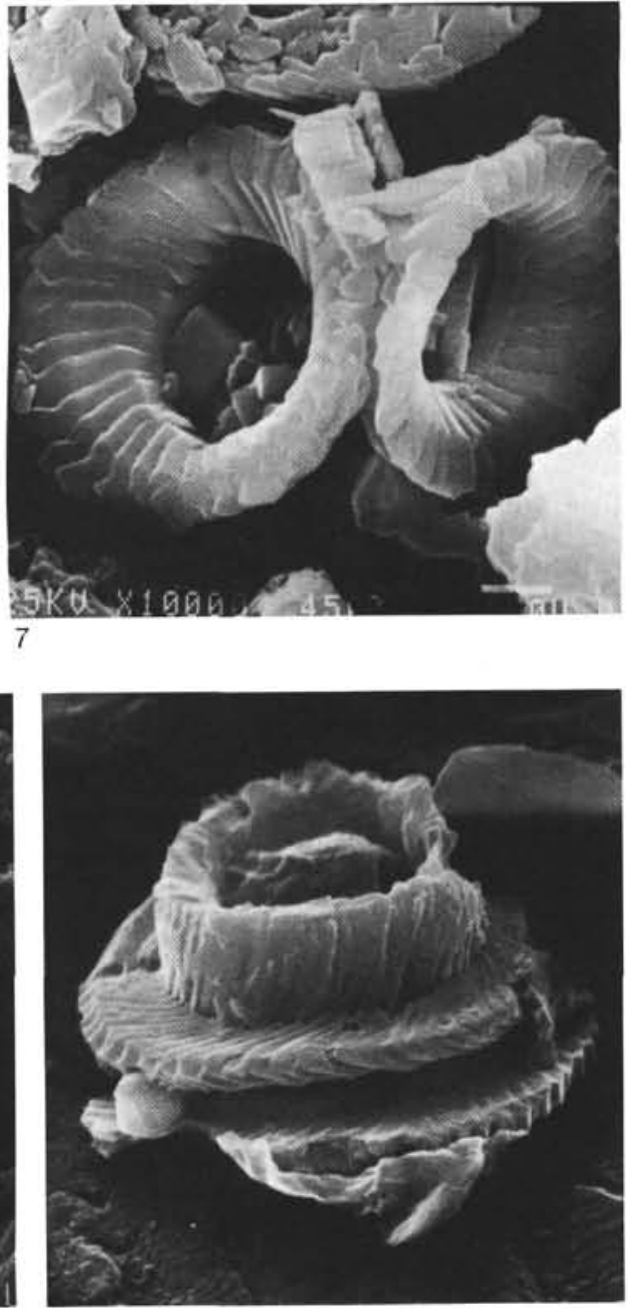

10

Plate 8. Rhagodiscaceae, Zygodiscaceae, Percivaliaceae, and Ellipsagelosphaeraceae. 1. Rhagodiscus infinitis (Worsley) Applegate, Covington, and Wise, n. comb., P, $\times 6500$, Sample 603B-44-1, $113 \mathrm{~cm}$. 2-4. Zeughrabdotus pseudoangustus Bralower, Applegate, Covington, and Wise, n. sp., (2) holotype, D, $\times 10,000$, Sample 603B-44-1, cm; (3) paratype, D, $\times 10,000$, Sample 603B-44-1, $120 \mathrm{~cm}$; (4) paratype, Pol, $\times 3500$, Sample 603B-46-2, $142 \mathrm{~cm}$. 5. Percivalia fenestratus (Worsley) Wise, D, $\times 7500$, Sample 603B-80,CC. 6, 7. Diazomatolithus lehmanii Noël, Sample 603B-76-2, $48 \mathrm{~cm},(6) \mathrm{L}$ and D, $\times 7000$; (7) D, $\times 7000$. 8. Manivitella pemmatoidea (Deflandre ex Manivit) Thierstein, D, $\times 5000$, Sample $603 \mathrm{~B}-48-1,113 \mathrm{~cm}$. 9, 10. Tubodiscus verenae Thierstein, L, Sample 603B-76-1, $64 \mathrm{~cm},(9) \times 5000 ;(10) \times 5500$. (Micrographs in Figs. 2 and 3 were taken by T. Bralower.) 


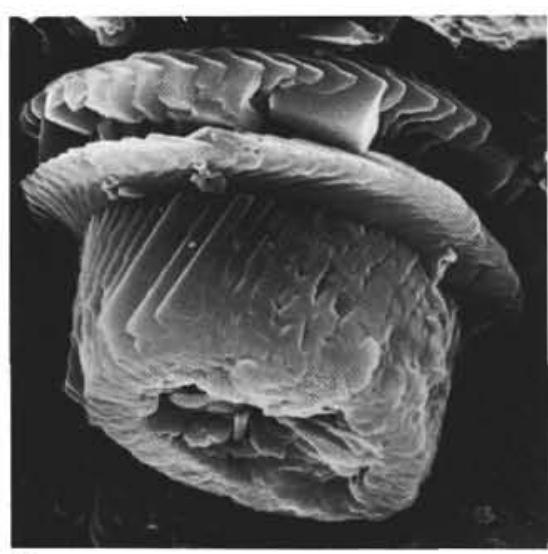

1

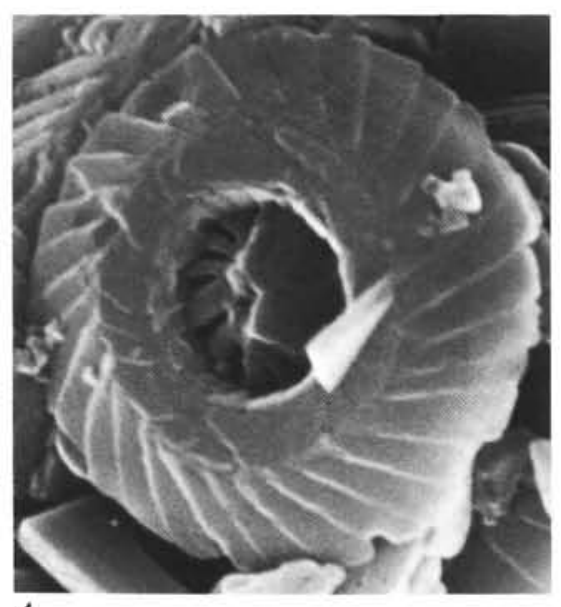

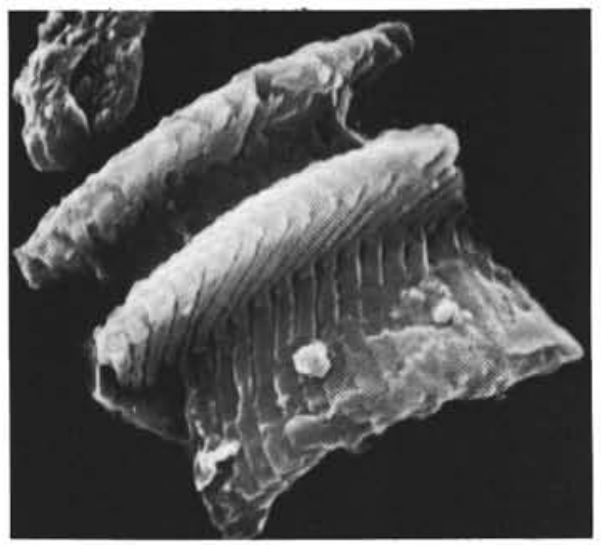

2

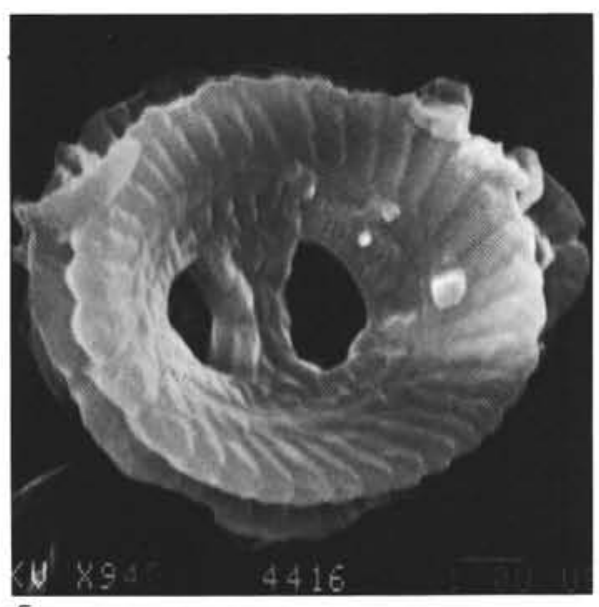

5
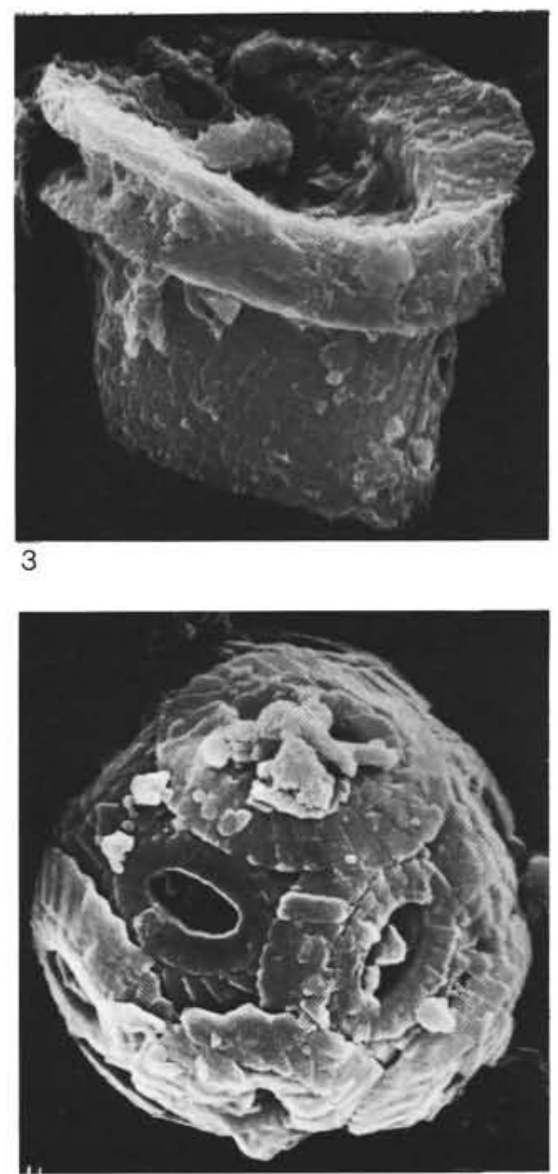

6

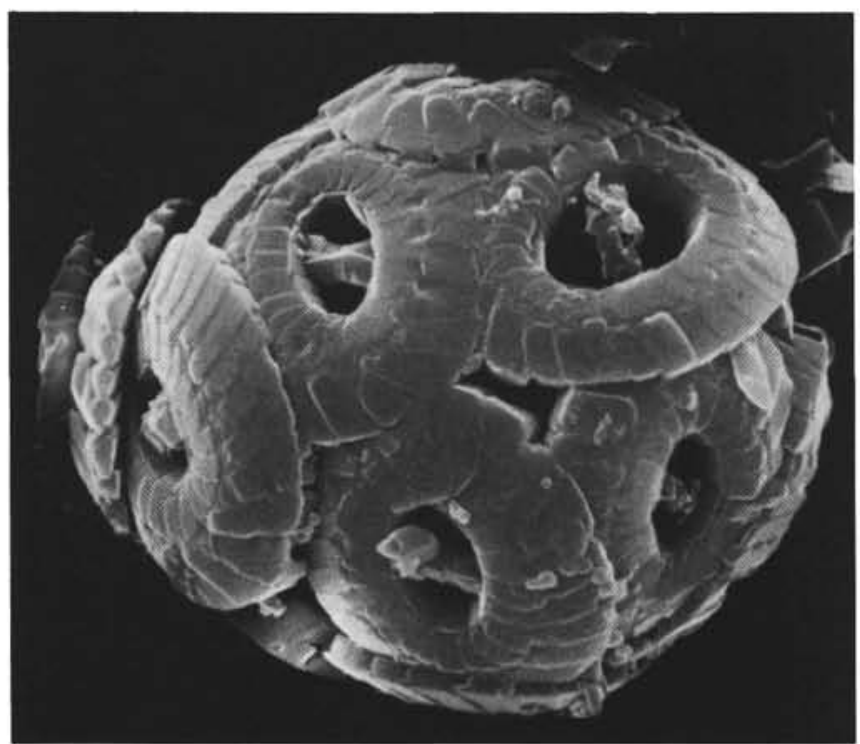

7

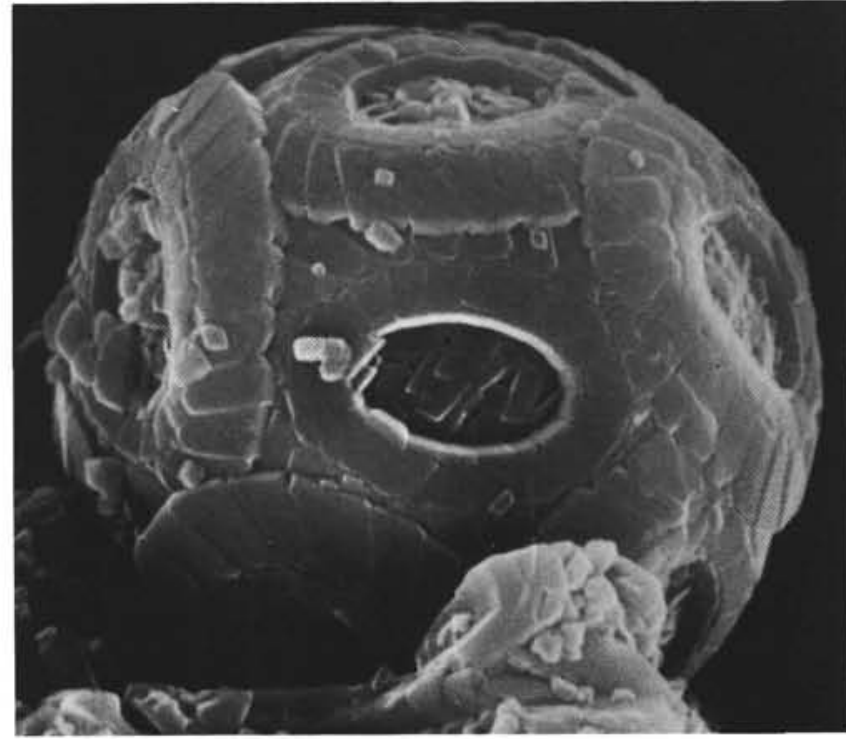

8

Plate 9. Ellipsagelosphaeraceae. 1-3. Tubodiscus verenae (Thierstein), L, Sample 603B-76-1, $136 \mathrm{~cm},(1) \times 5000 ;(2) \times 8000 ;(3) \times 5500$. 4. Cyclagelosphaera jiangii Covington and Wise, n. sp., holotype, D, $\times 12,000$, Sample 603B-76-1, $136 \mathrm{~cm} . \quad$ 5, 7. Watznaueria britannica (Stradner) Reinhardt, (5) P, $\times 7000$, Sample 603B-44-1, $113 \mathrm{~cm}$; (7) $\times 8500$, Sample 603B-76-1, $136 \mathrm{~cm}$. 6. Watznaueria sp., $\times 5500$, Sample 603B-57-1, $134 \mathrm{~cm}$. 8. Watznaueria fasciata(?) Wind and Cepek,, $\times 10,500$, Sample 603B-76-1, $136 \mathrm{~cm}$ (overgrown central areas?). 

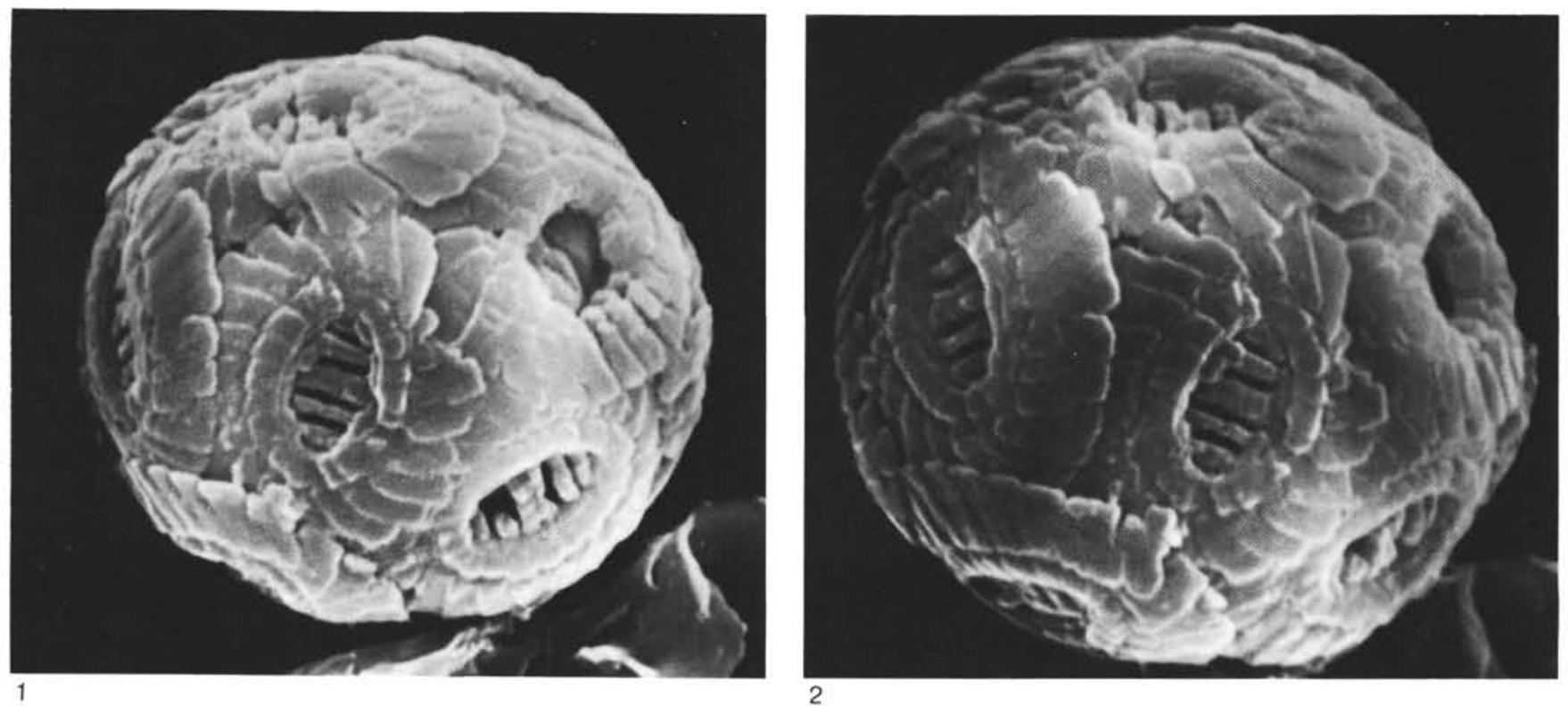

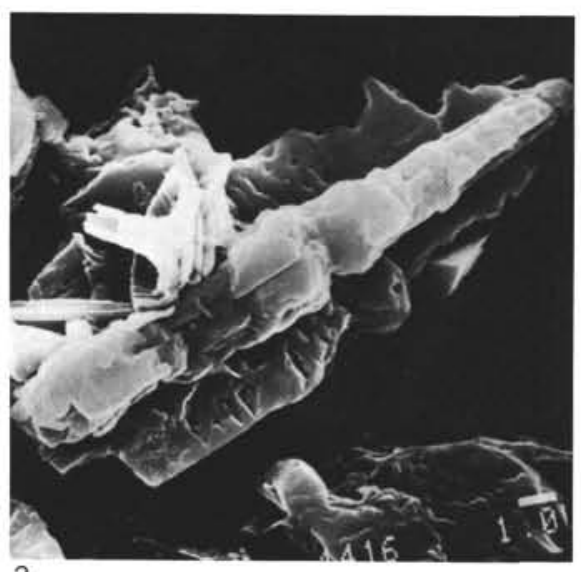

3

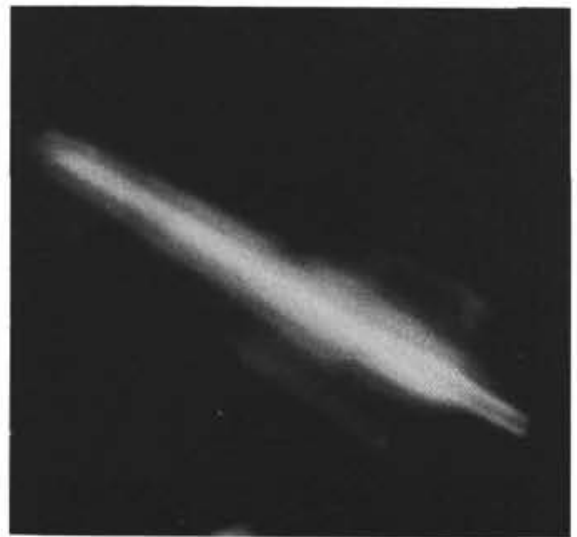

6

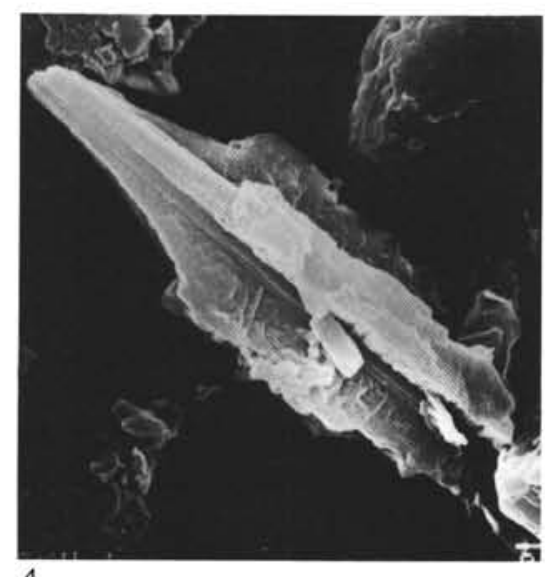

4

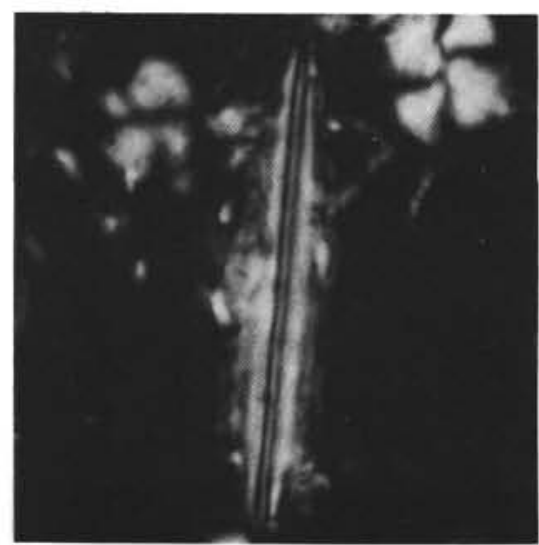

7

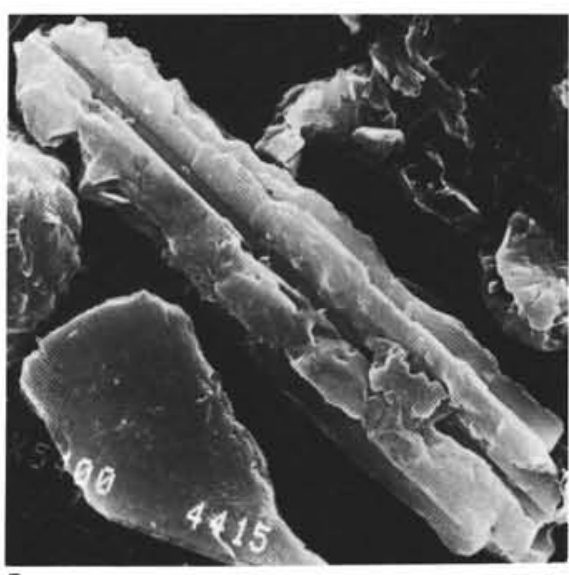

5

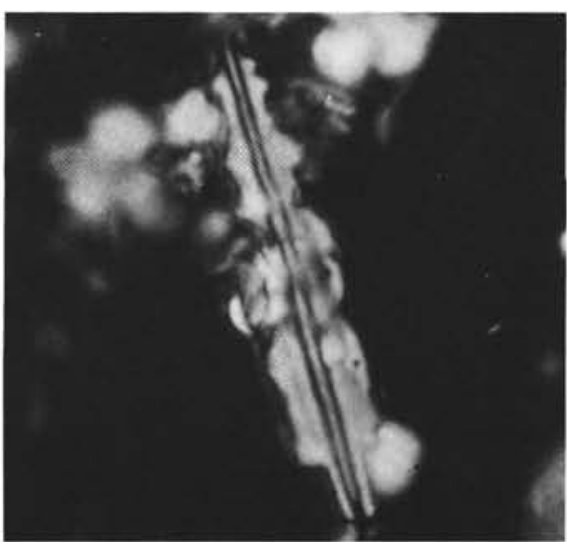

8

Plate 10. Ellipsagelosphaeraceae and Microrhabdulaceae. 1, 2. Watznaueria fasciata Wind and Čepek, Sample $603 \mathrm{~B}-55-1,100 \mathrm{~cm},(1) \times 11,500$;

(2) $\times 13,500$. 3, 4. Lithraphidites alatus magnus Covington and Wise n. ssp., L, Sample 603B-44-1, $97 \mathrm{~cm},(3)$ holotype, $\times 4000$; (4) paratype, $\times 3500$. 5, 8. Lithraphidites alatus sp. cf. L. alatus magnus Covington and Wise, n. ssp., L, $(5) \times 3750$, Sample $603 \mathrm{~B}-44-1,97 \mathrm{~cm}$; $(8)$ Pol, $\times 2500$, Sample 603B-46-2, $142 \mathrm{~cm}$. 6, 7. Lithraphidites sp., Pol, Sample 603B-44-1, $95 \mathrm{~cm},(6) \times 3250 ;(7)$ Pol, $\times 2500$. 

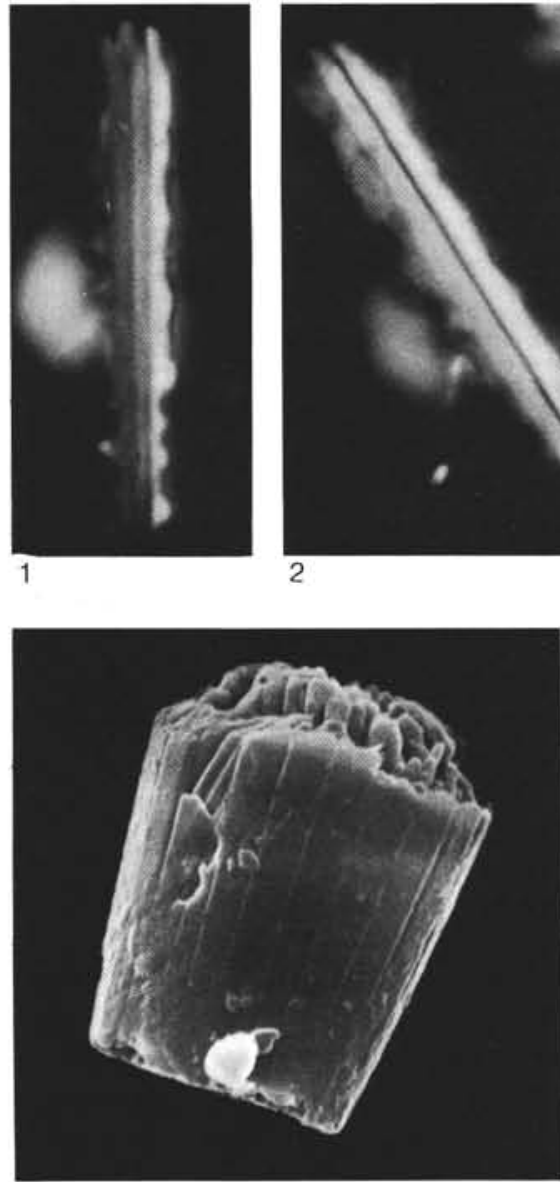

5

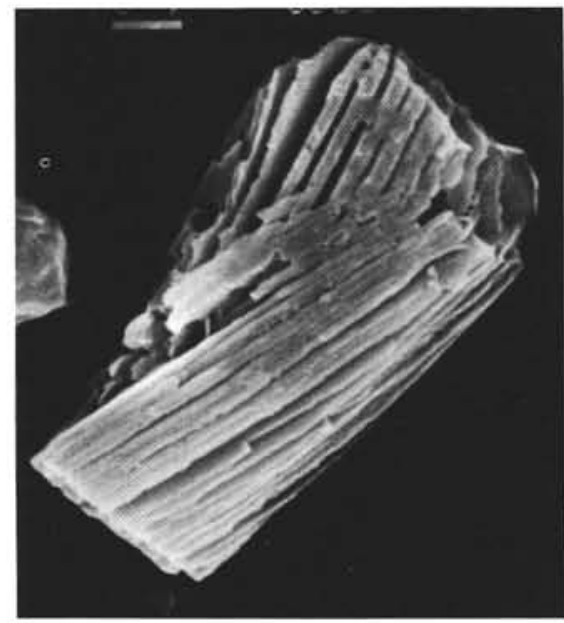

2
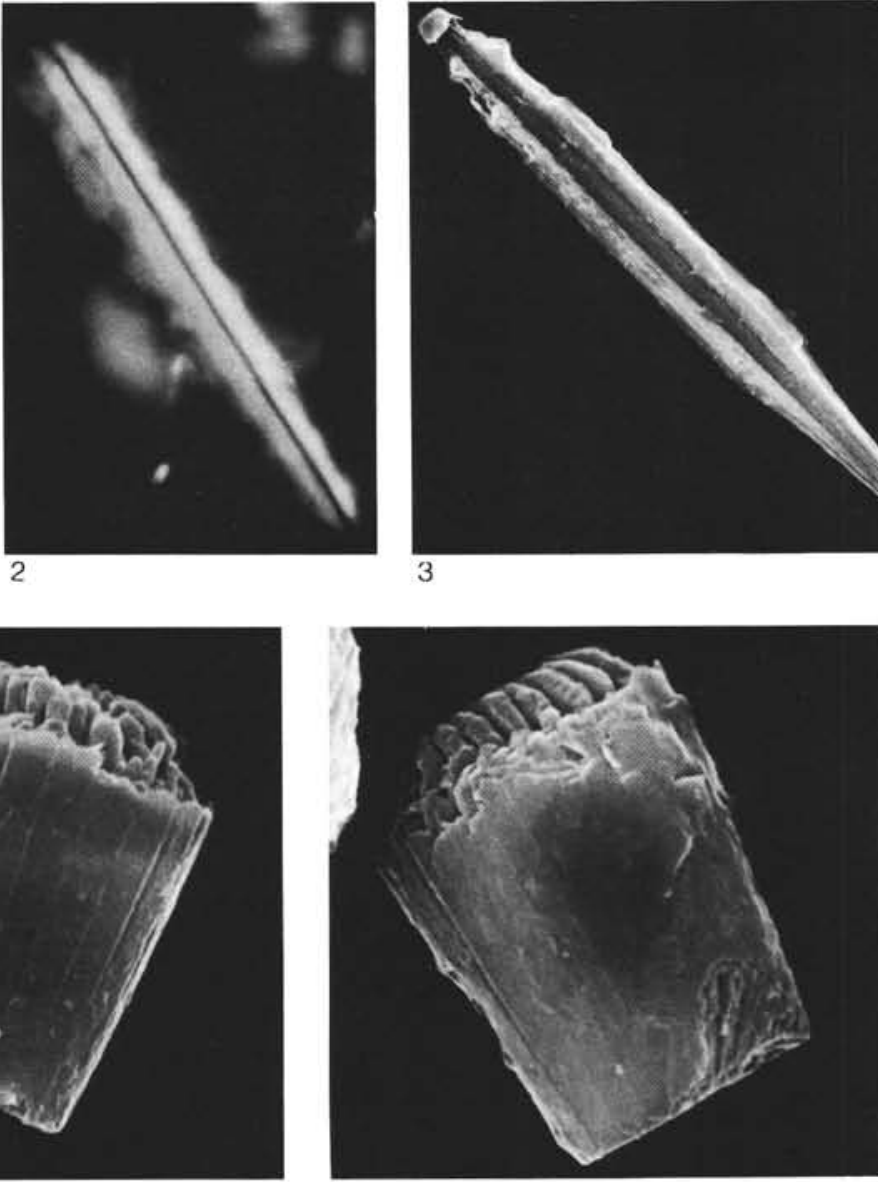

6

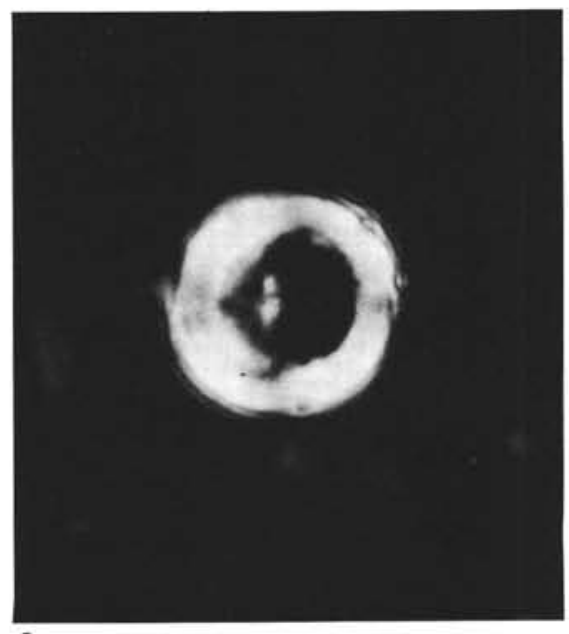

9

3
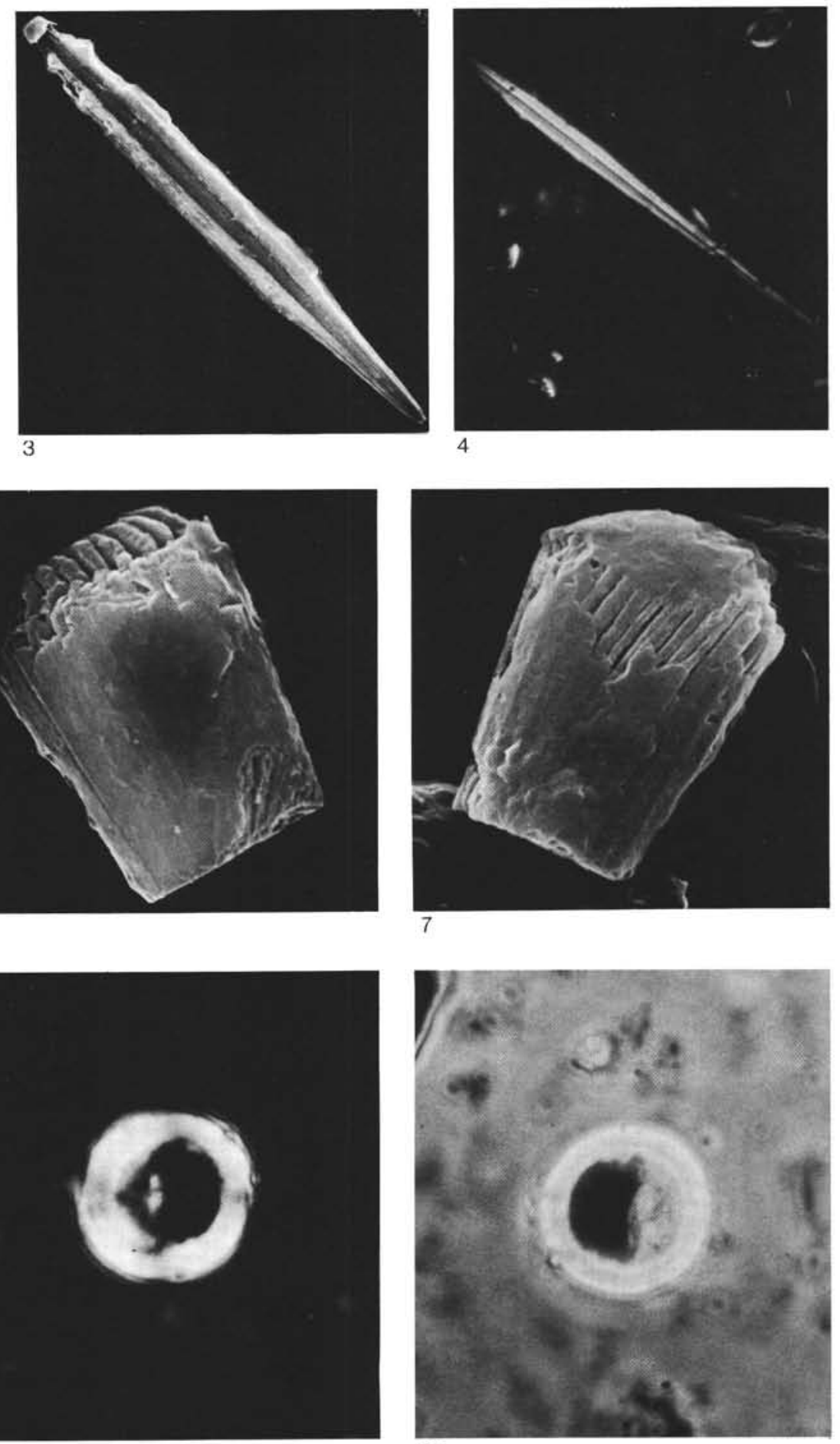

10

Plate 11. Microrhabdulaceae, Crepidolithaceae, and Nannoconaceae? 1, 2. Lithraphidites sp., Sample 603B-44-1, 97 cm, (1) Pol, $\times 3500 ;(2)$ at $45^{\circ}$, Pol, $\times 3000$. 3. Rhabdophidites aquitanicus (Manivit) Applegate, Covington, and Wise, n. comb., Sample $603 \mathrm{~B}-44-1,97 \mathrm{~cm}, \times 3750$. 4. Lithraphidites carniolensis Deflandre, Pol, $\times 1520$, Sample 603B-54,CC. 5-8. Conusphaera mexicana Trejo, L, (5) $\times 7000$, Sample $603 \mathrm{~B}-44-$ 2, $145 \mathrm{~cm} ;(6) \times 7000$, Sample 603B-57-1, $34 \mathrm{~cm}$; (7) $\times 7000$, Sample 603B-60-1, $109 \mathrm{~cm}$; (8) $\times 7000$, Sample 603B-57-1, 34 cm. 9, 10. Nannoconus? sp., Sample 603B-55,CC, $\times 2500$, (9) Pol; (10) Ph. 


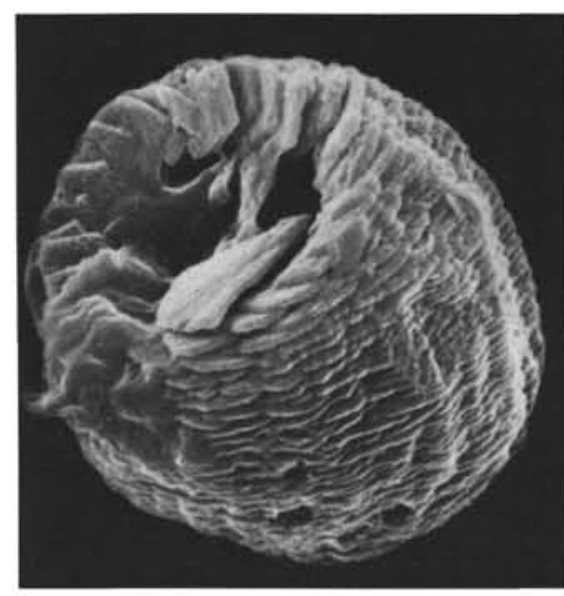

1

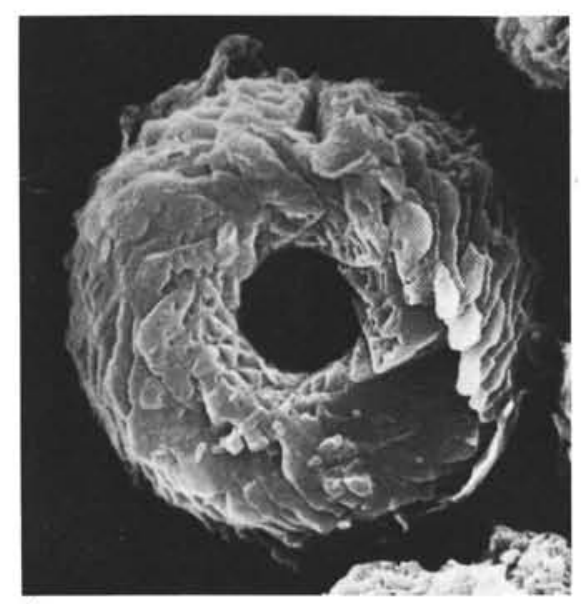

4

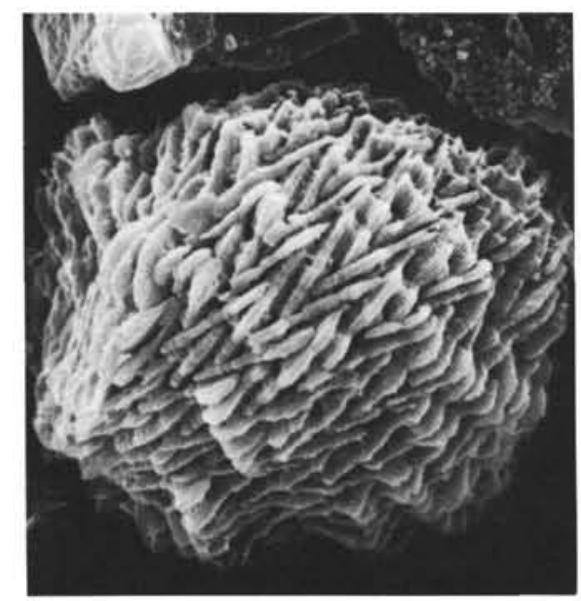

7

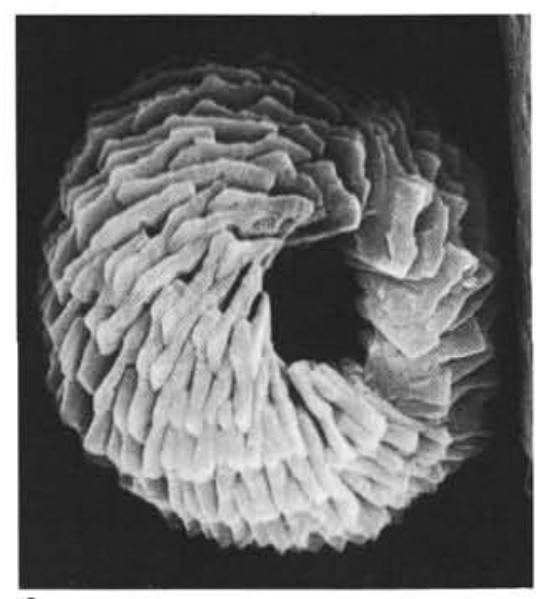

2

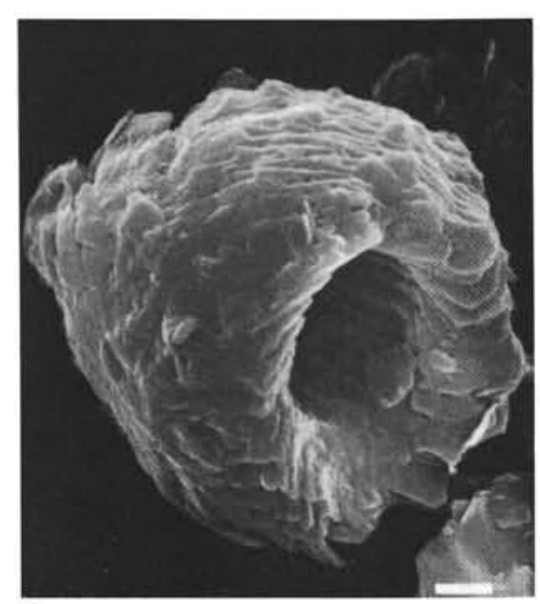

5

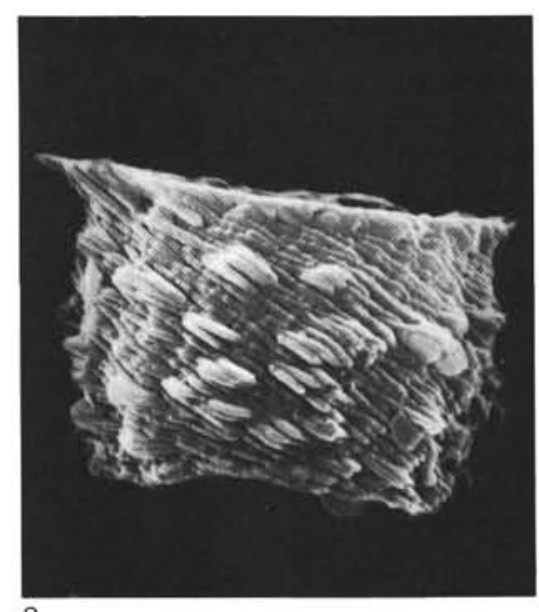

8

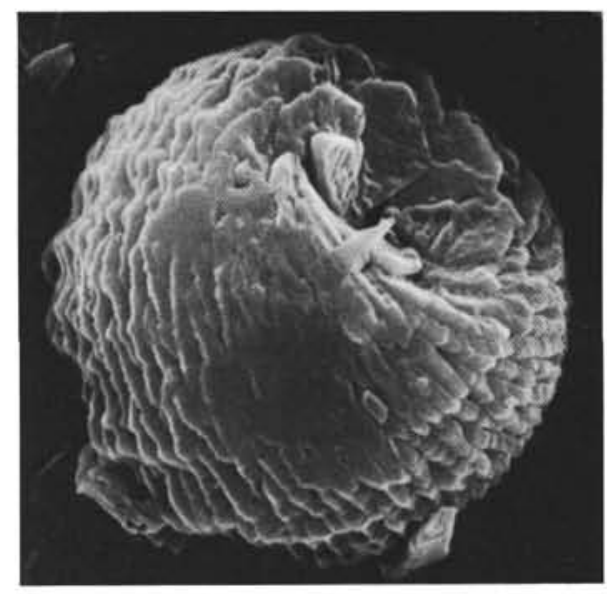

3

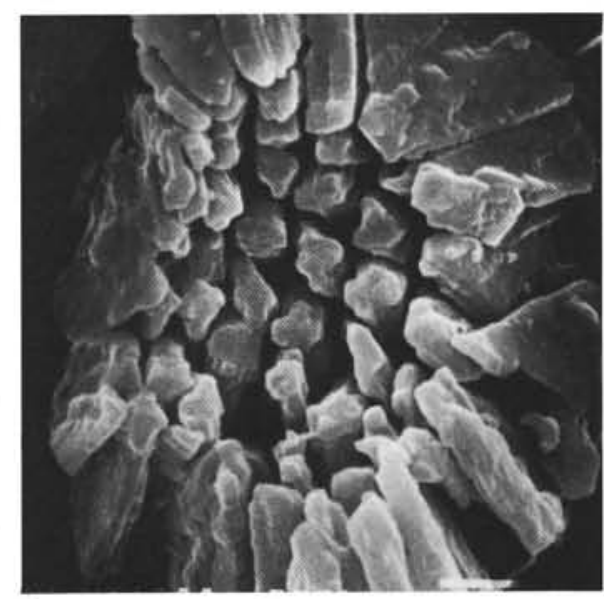

6

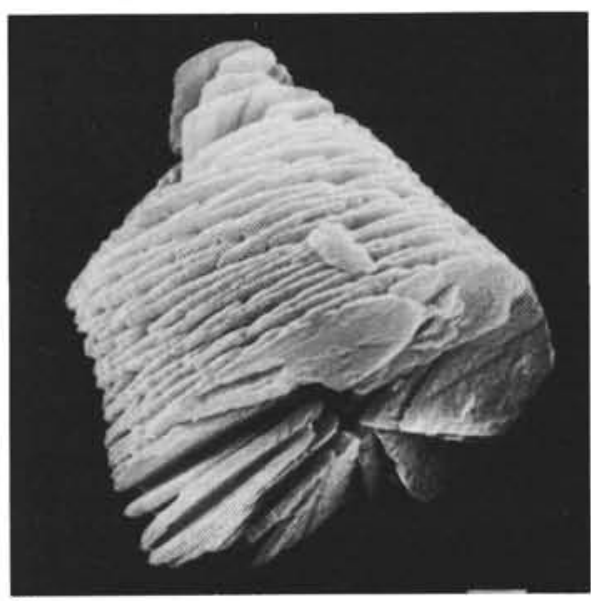

Plate 12. Nannoconaceae. 1-6. Nannoconus globulus? Brönnimann, $(1,2)$ Sample 603B-44,CC, $(1, \times 6500 ; 2, \times 6500)$; (3) Sample 603B-57-1, $34 \mathrm{~cm} ; \times 8000$; (4-6) Sample 603B-55-3, $100 \mathrm{~cm},(4, \times 6500 ; 5, \times 6000 ; 6, \times 8000$, internal view). 7. Nannoconus sp., Sample 603B-44,CC, $\times 6000$. 8. Nannoconus abundans Stradner and Grün, Sample $603 \mathrm{~B}-44, \mathrm{CC}, \times 6000$. 9. Nannoconus steinmannii, Kamptner, Sample $603 \mathrm{~B}-$ $44-1,113 \mathrm{~cm}, \times 6000$. 


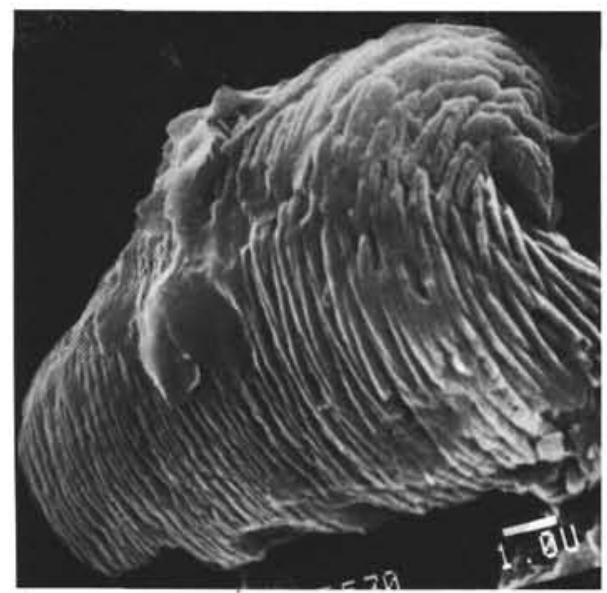

1

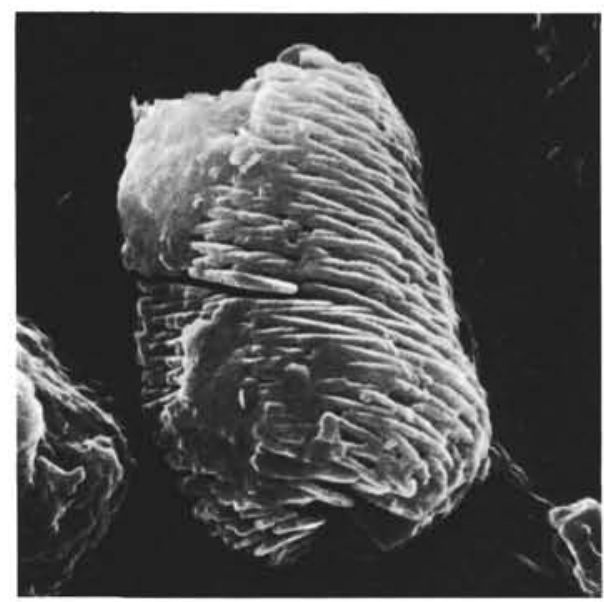

4

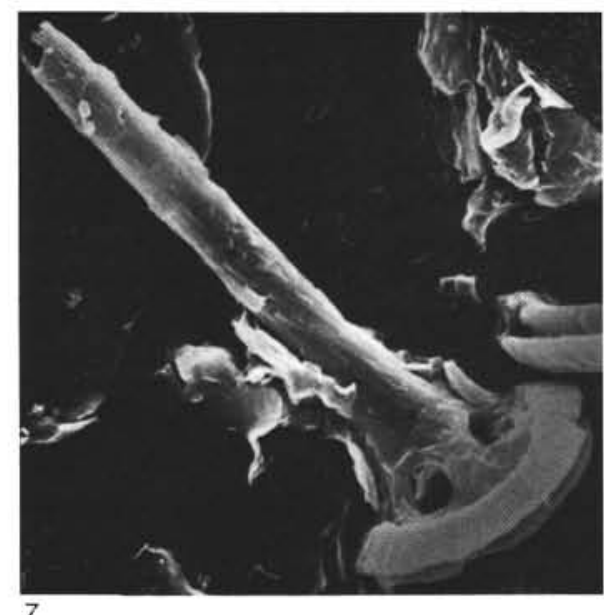

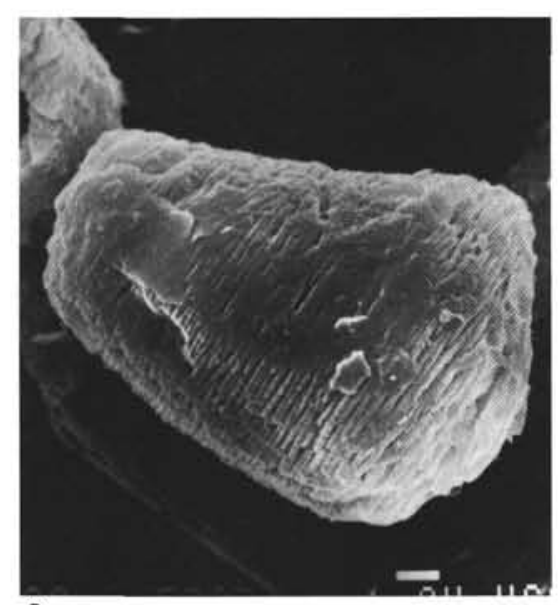

2

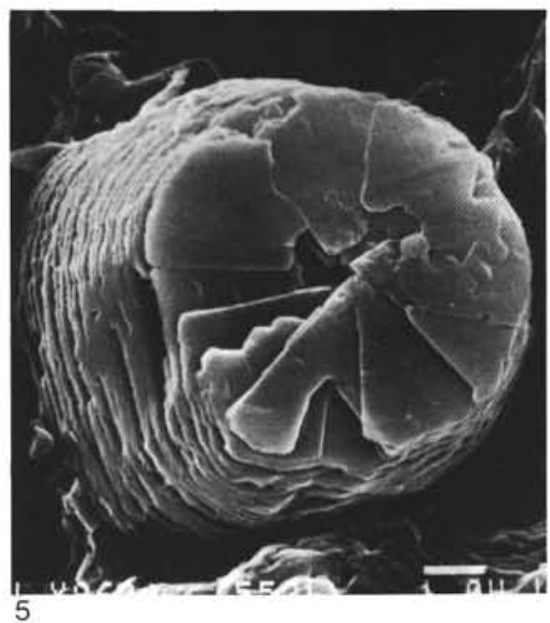

5

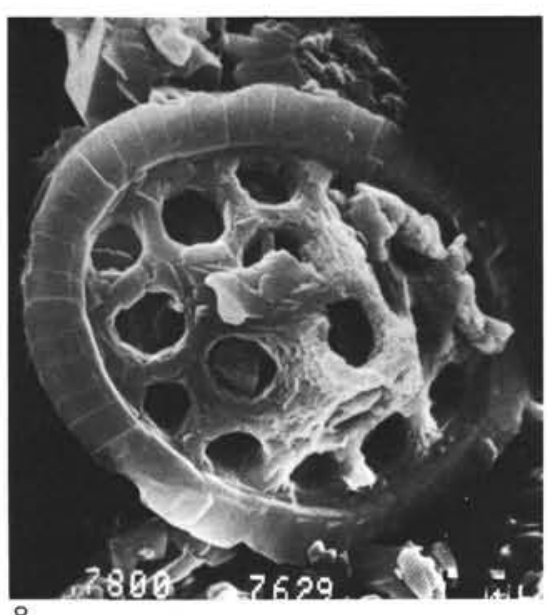

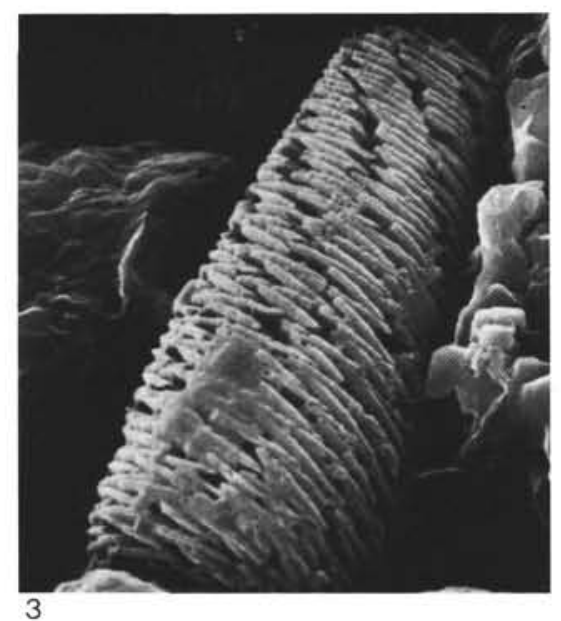

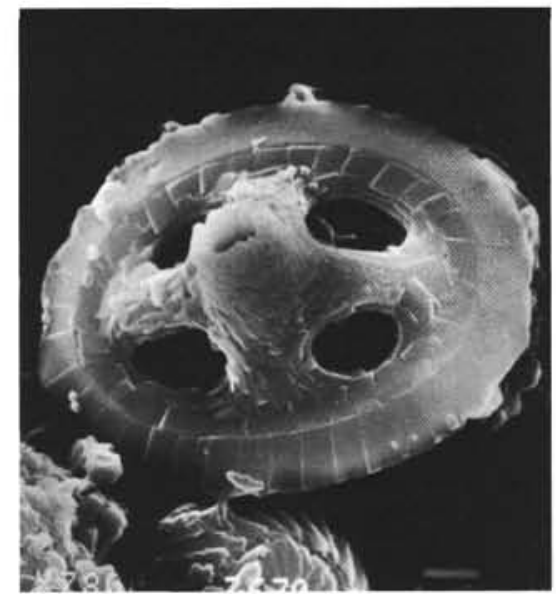
6

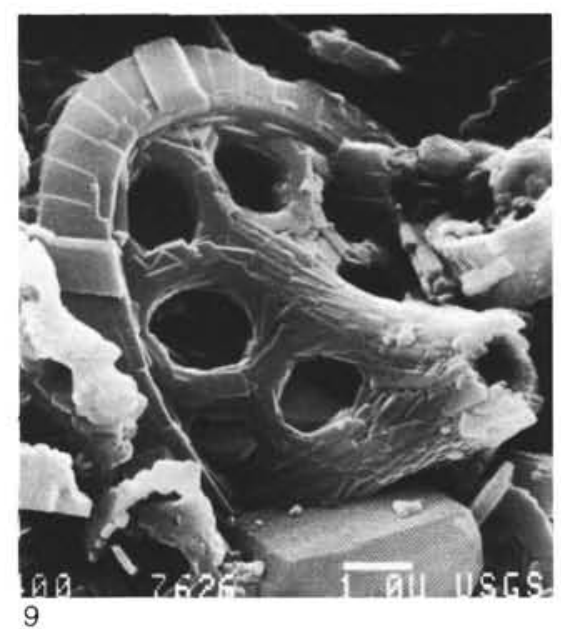

Plate 13. Nannoconaceae and Podorhabdaceae. 1, 2, 4, 5. Nannoconus steinmannii Kamptner, (1) $\times 5500$, Sample $603 \mathrm{~B}-55-3$, 100 cm; (2) $\times 4500$, Sample 603B-57-1, $34 \mathrm{~cm}$; (4) $\times 6000$, Sample 603B-57-1, $34 \mathrm{~cm}$; (5) $\times 6500$, Sample 603B-55-2, $100 \mathrm{~cm}$. 3. Nannoconus bermudezii Brönnimann, $\times 6000$, Sample 603B-49-2, $105 \mathrm{~cm}$. 6, 7. Axopodorhabdus sp. cf. A. dietzmannii Reinhardt, (6) D, $\times 6000$, Sample 603B-76-3, $27 \mathrm{~cm}$; (7) D, $\times 5000$, Sample 603B-44-1, $97 \mathrm{~cm} .8$ 8.9. Octopodorhabdus plethotretus Wind and Cepek ex Applegate, Covington, and Wise, Sample 603B-76-2, $48 \mathrm{~cm},(8) \mathrm{D}, \times 5500$; (9) D, $\times 7000$. 

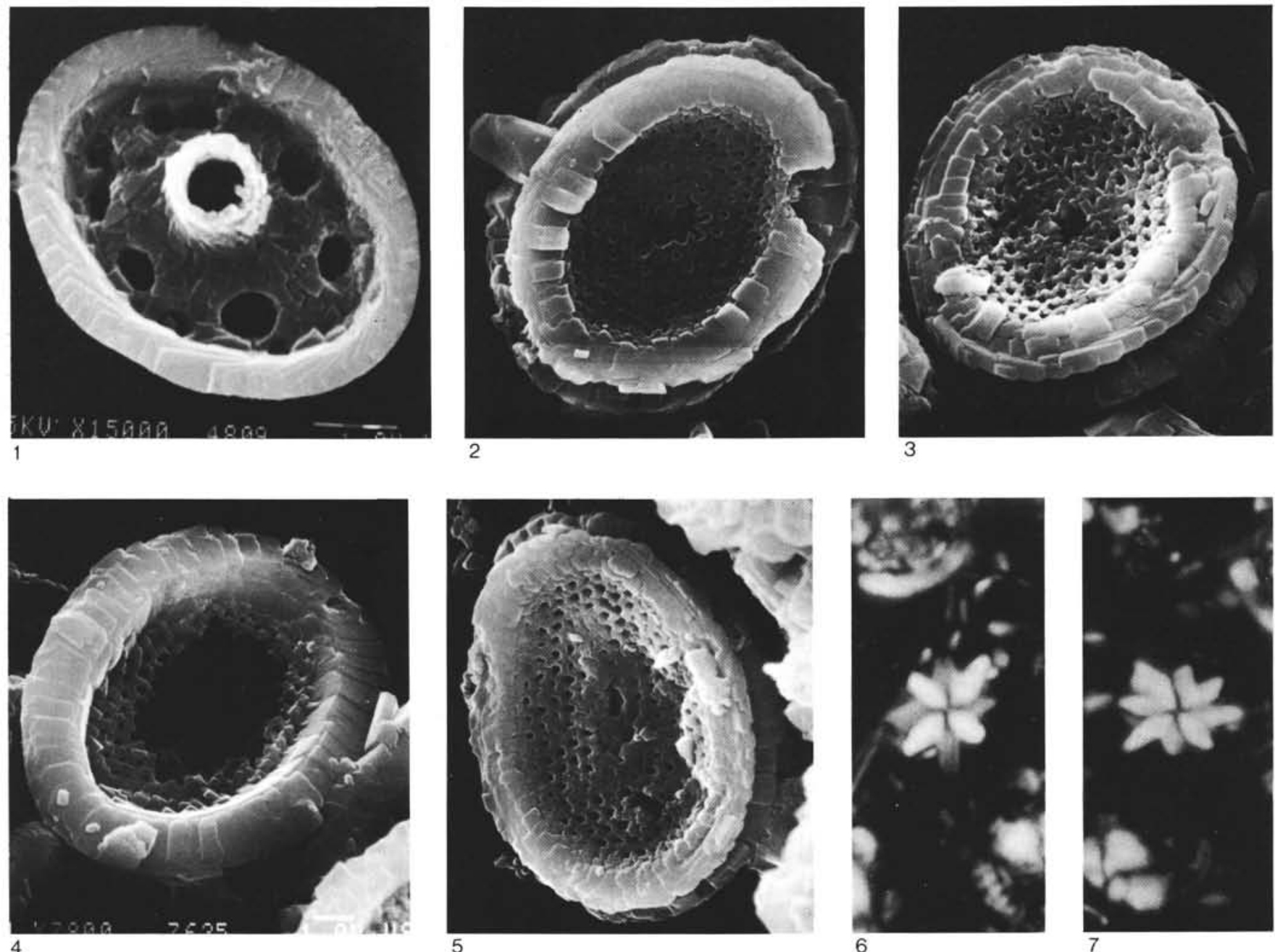

4

\section{5}

\section{6}
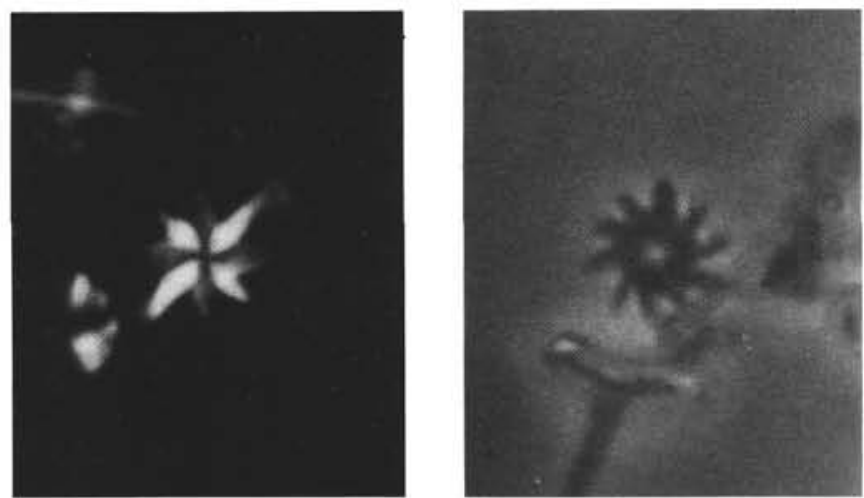

11

Plate 14. Podorhabdaceae, Polycyclolithaceae, and Biscutaceae. 1. Perissocvclus? sp. cf. P. noeliae Black, emend. Wind and Čepek, D, $\times 10,500$, Sample 603B-48-1, $113 \mathrm{~cm}$. 2-5. Ethmorhabdus? hauterivianus (Black) Applegate, Covington, and Wise, n. comb., Sample 603B-76-2, 48 cm, (2) P, $\times 5500$; (3) P, $\times 5500$; (4) P, $\times 6500$; (5) D, $\times 5500$. 6, 7. "Hayesites"? sp., Pol, (6) $\times 4000$, Sample 603B-52-2, 144 cm; (7) same specimen rotated $45^{\circ}$. 8-10. "Rucinolithus? radiatus" Worsley (= "Hayesites bulbus" Thierstein), $\times 3500$, Sample 603B-52-4, 144 cm, (8) Ph; (9) Pol; (10) Pol, rotated $45^{\circ}$. 11. Discorhabdus biradiatus (Worsley) Thierstein, $\mathrm{Ph}, \times 2500$, Sample $603 \mathrm{~B}-55-3,145 \mathrm{~cm}$. 

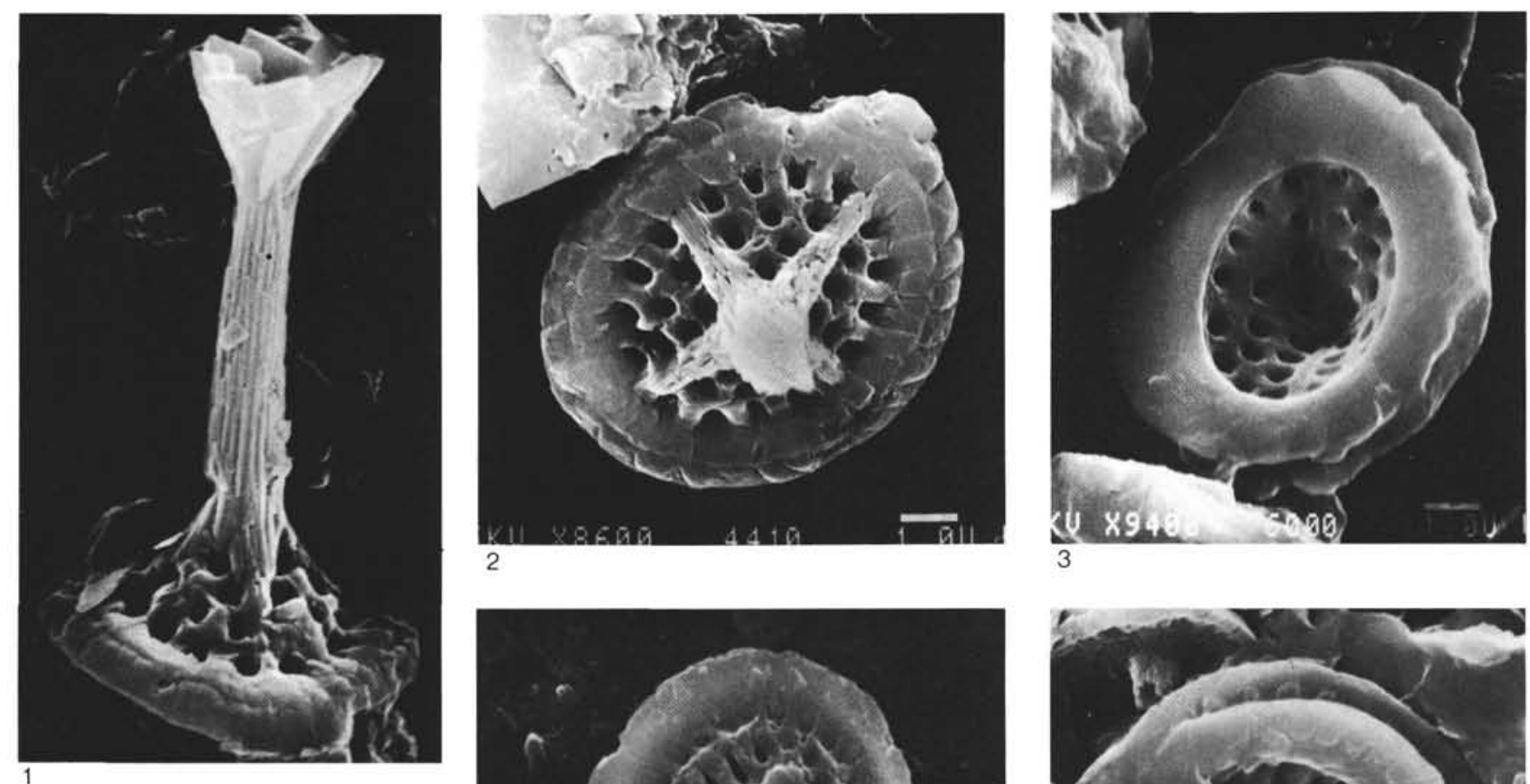

2
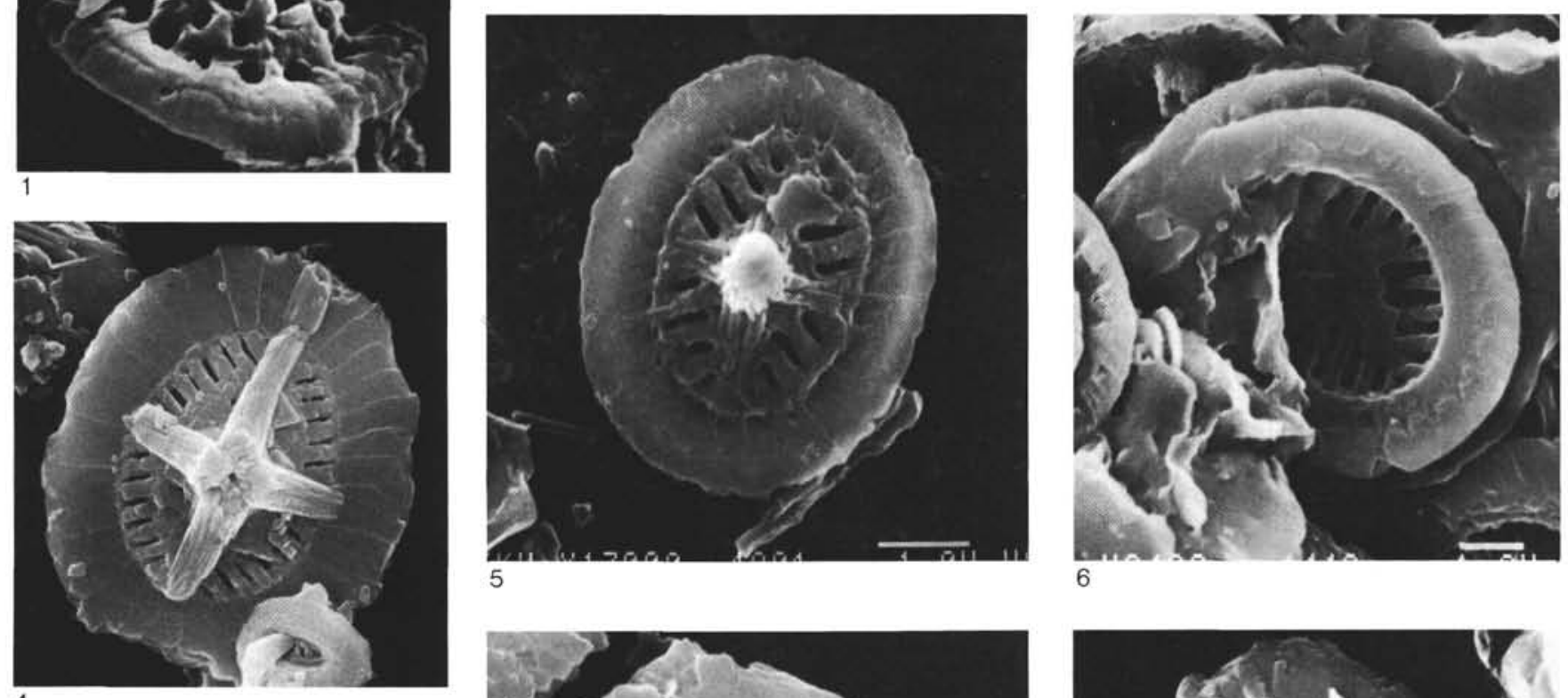

5
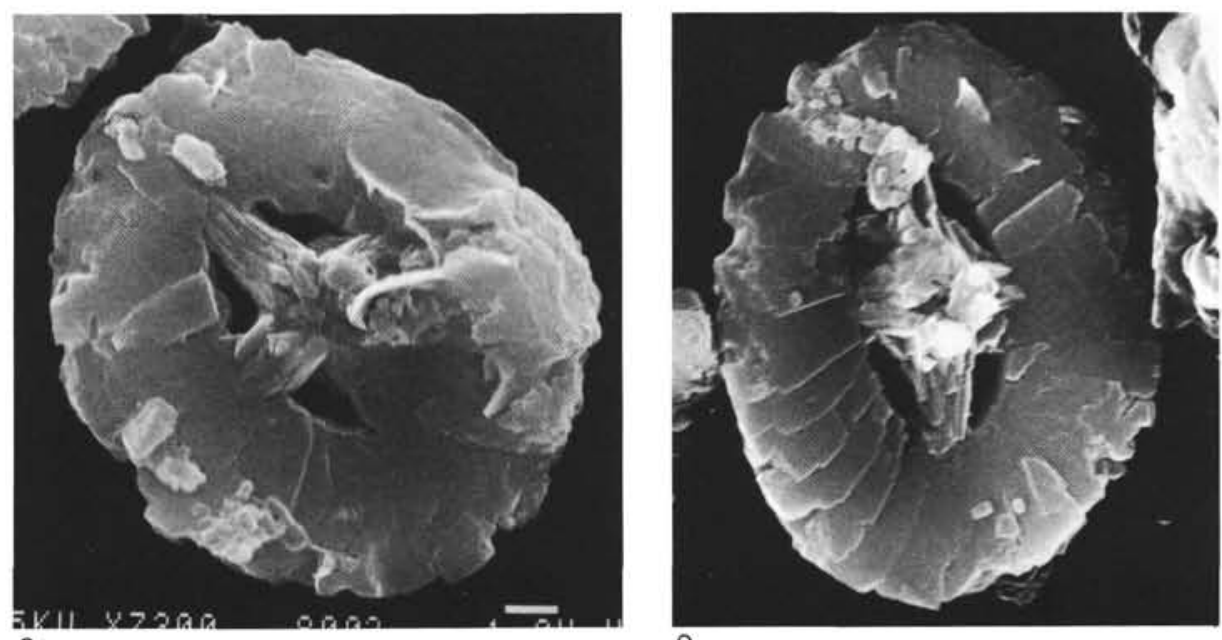

8

9

Plate 15. Podorhabdaceae. 1-3. Cretarhabdus conicus Bramlette and Martini, $(1,2)$ Sample $603 \mathrm{~B}-44-1,97 \mathrm{~cm},(1, \mathrm{D}, \times 6500 ; 2, \mathrm{D}, \times 7000) ;(3)$ P, $\times 7000$, Sample 603B-60-1, $109 \mathrm{~cm}$. 4. Cretarhabdus? sp., D, $\times 4500$, Sample 603B-76-2, $48 \mathrm{~cm} . \quad$ 5, 6. Polypodorhabdus madingleyensis Black, (5) D, $\times 10,000$, Sample 603B-48-1, $113 \mathrm{~cm}$; (6) P, $\times 7000$, Sample 603B-44-1, $113 \mathrm{~cm}$. 7-9. Cruciellipsis cuvilleri (Manivit) Thierstein, (7) D, $\times 6500$, Sample 603B-76-2, $48 \mathrm{~cm}$; (8-9) D, Sample 603B-80,CC, $(8, \times 5500 ; 9, \times 6500)$. 

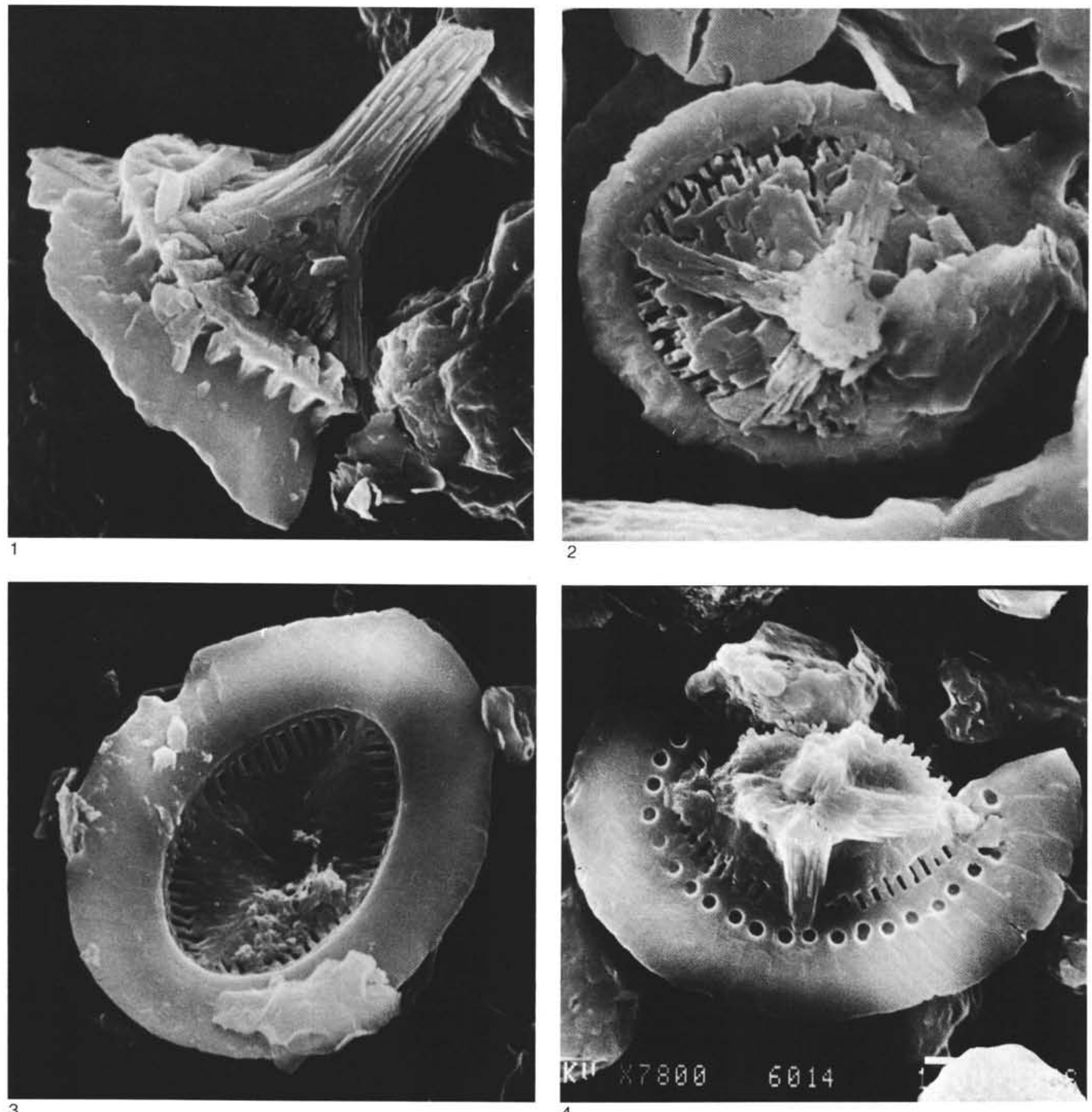

4

Plate 16. Podorhabdaceae. 1, 2. Picklehaube furtiva (Roth), Applegate, Covington, and Wise, emend., n. comb., Sample 603B-44-1, 113 cm, (1) L, $\times 9000$; (2) D, $\times 11,500$. 3, 4. Cretarhabdus? delicatus Applegate, Covington, and Wise, n. sp., (3) paratype, $\mathrm{P}, \times 10,000$, Sample 603B-48$1,113 \mathrm{~cm}$; (4) holotype, D, $\times 7000$, Sample 603B-60-1, $109 \mathrm{~cm}$. 

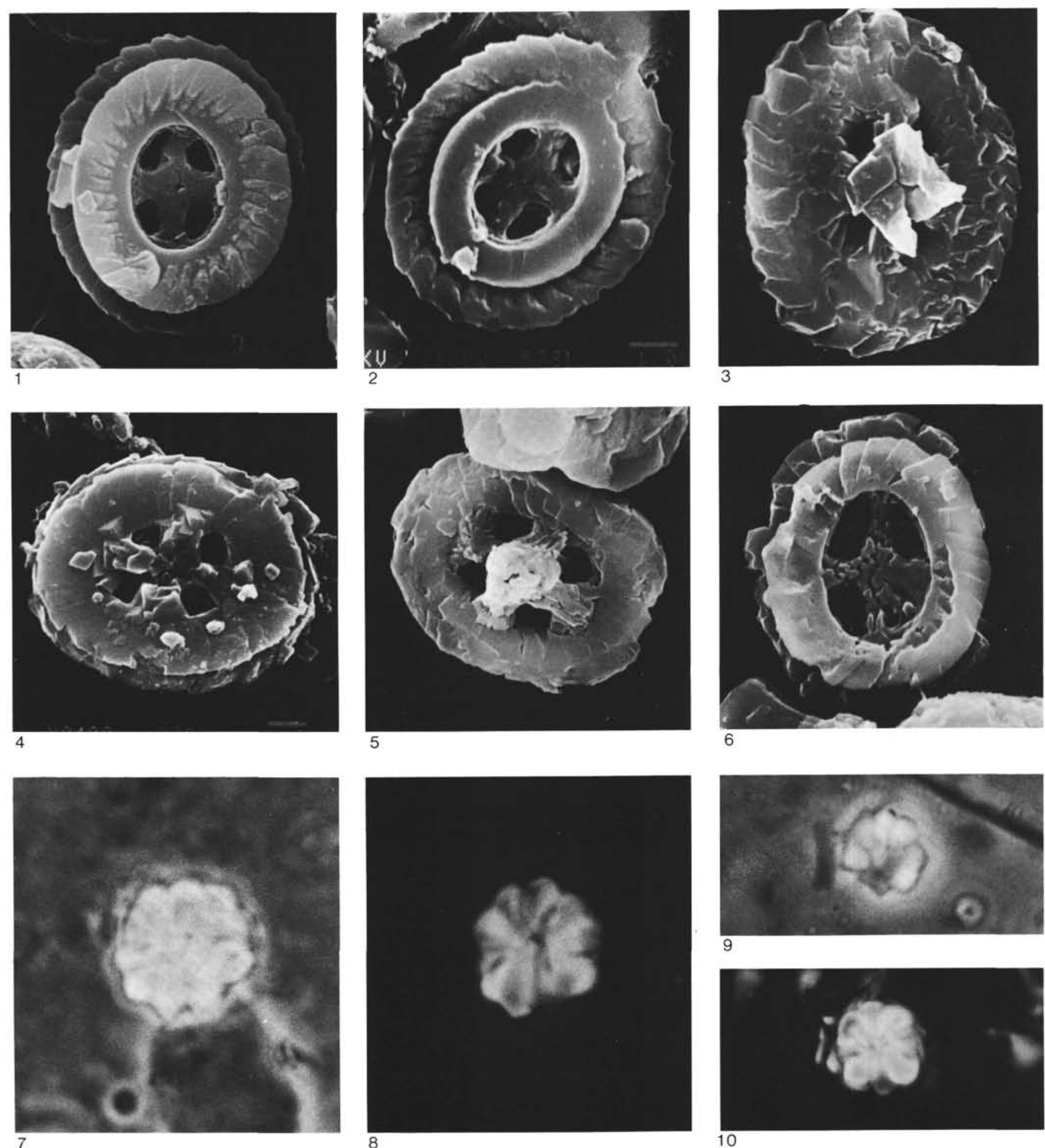

Plate 17. Podorhabdaceae and Polycyclolithaceae. 1-6. Microstaurus chiastius (Worsley) Grün, (1) P, $\times 7500$, Sample $603 \mathrm{~B}-44-1,113 \mathrm{~cm}$; (2) $\mathrm{P}$, $\times 8500$, Sample 603B-57-2, $131 \mathrm{~cm}$; (3) D, $\times 8500$, Sample 603B-55-2, $40 \mathrm{~cm}$; (4) P, $\times 6500$, Sample 603B-82-2, $145 \mathrm{~cm}$; (5) D, $\times 8000$, Sample 603B-44-1, $113 \mathrm{~cm}$; (6) P, $\times 6500$, Sample 603B-76-1, $136 \mathrm{~cm}$. 7, 8. Rucinolithus terebrodentarius Applegate, Bralower, Covington, and Wise, n. sp., same specimen, $\times 3400$, Sample 603B-54,CC, (7) $\mathrm{Ph}$; (8) Pol. 9, 10. Rucinolithus? sp., same specimen, Sample 603B-56-2, 54 cm, (9) $\mathrm{Ph}, \times 3250 ;(10) \mathrm{Pol}, \times 2500$. 


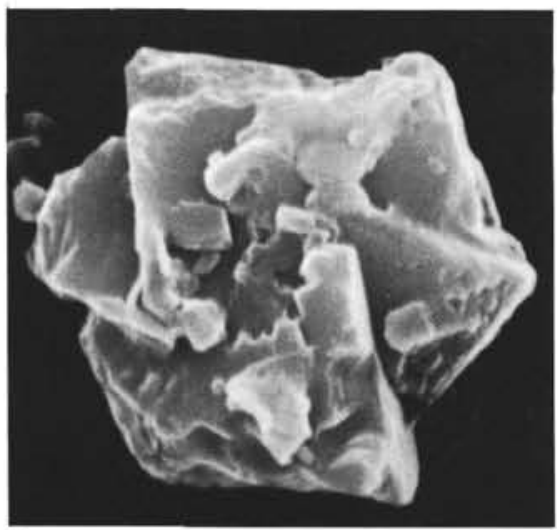

1

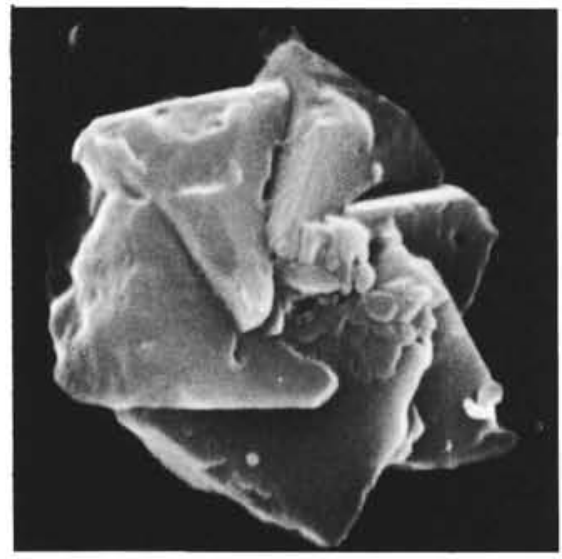

4

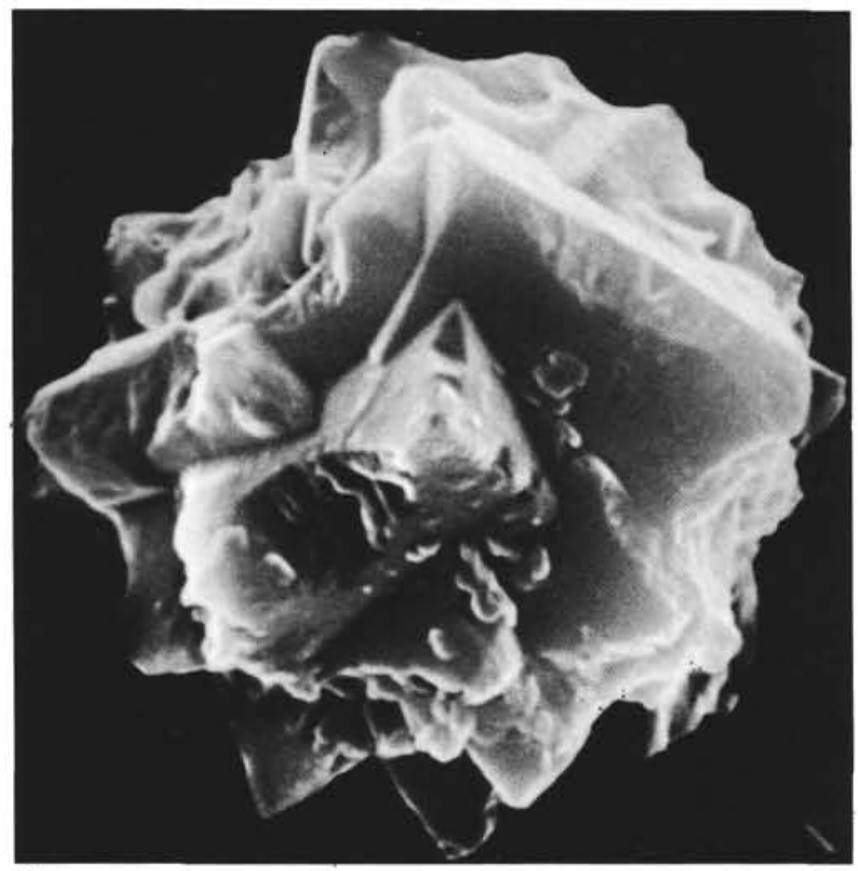

6

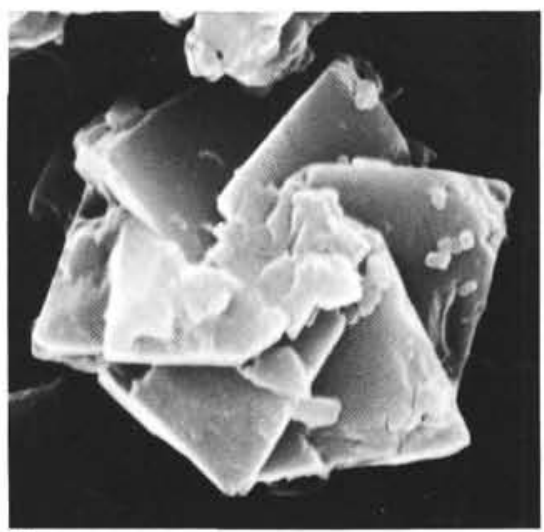

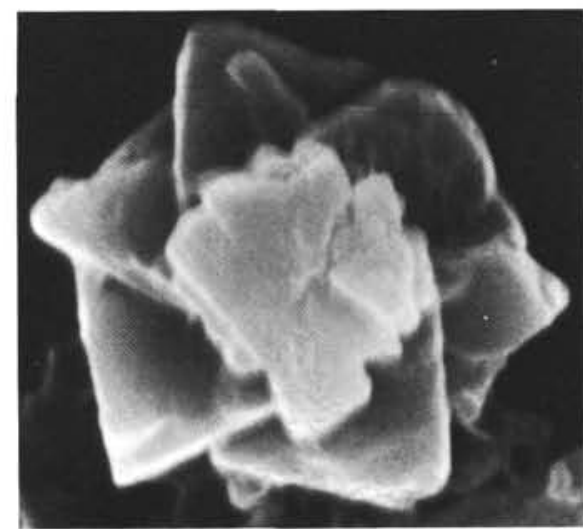

3

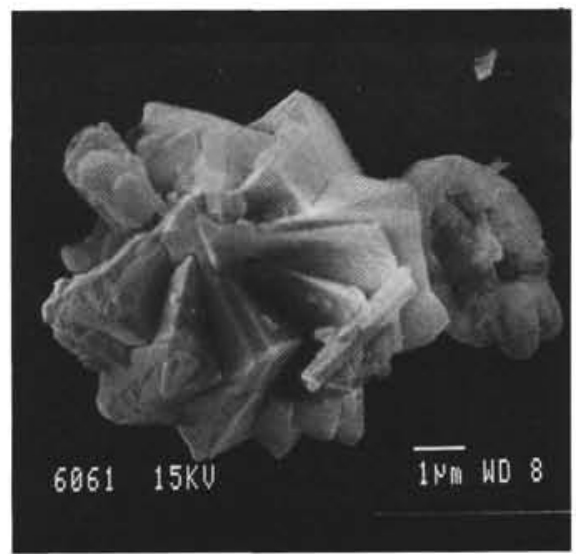

5

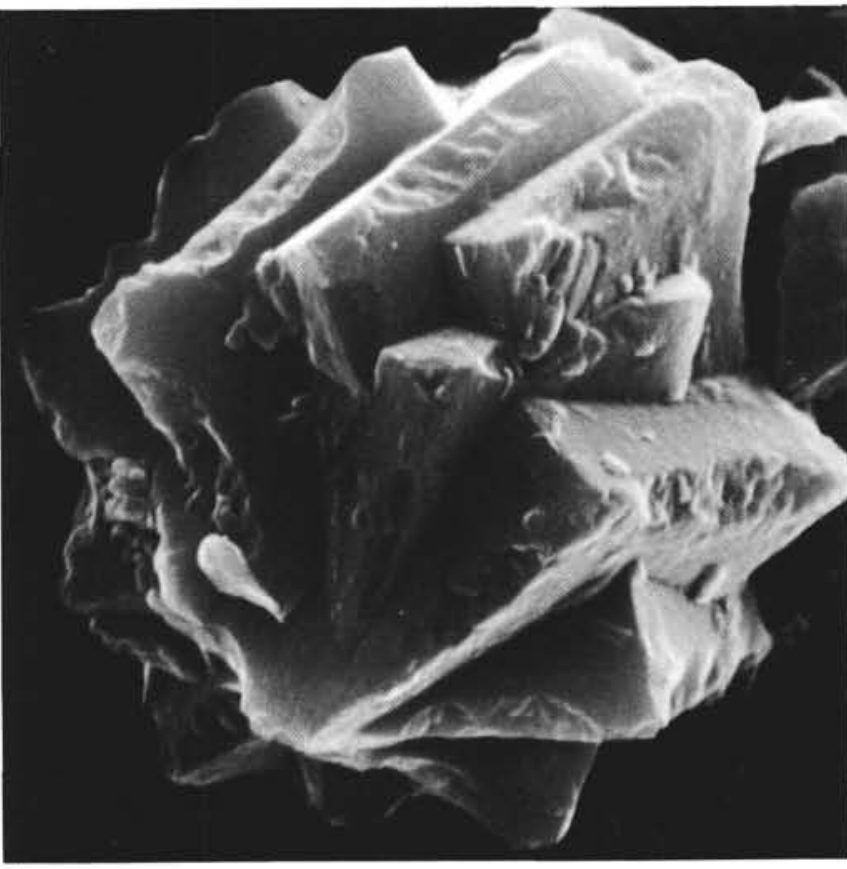

7

Plate 18. Polycyclolithaceae. 1-4. Rucinolithus wisei Thierstein, Sample $603 \mathrm{~B}-79-3,134 \mathrm{~cm},(1) \times 11,000 ;(2) \times 9000,(3) \times 20,000 ;(4) \times 11,000$

5-7. Rucinolithus terebrodentarius Applegate, Bralower, Covington, and Wise, n. sp., (5) paratype, $\times 5,000$, Sample $603 \mathrm{~B}-44-1,60 \mathrm{~cm},(6,7)$ Sample 603B-44-1, $113 \mathrm{~cm},(6$, paratype, axial view, $\times 13,000 ; 7$, holotype, $\times 11,000$. 


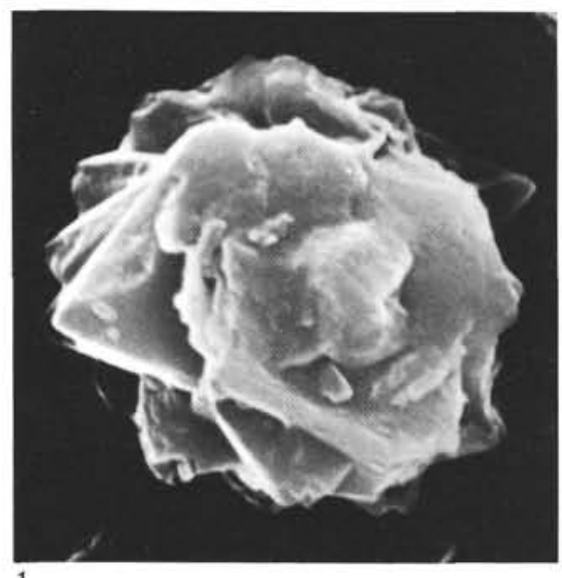

1

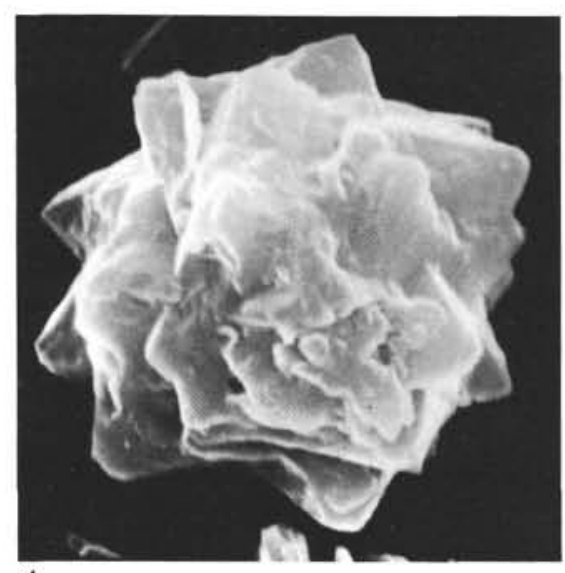

4

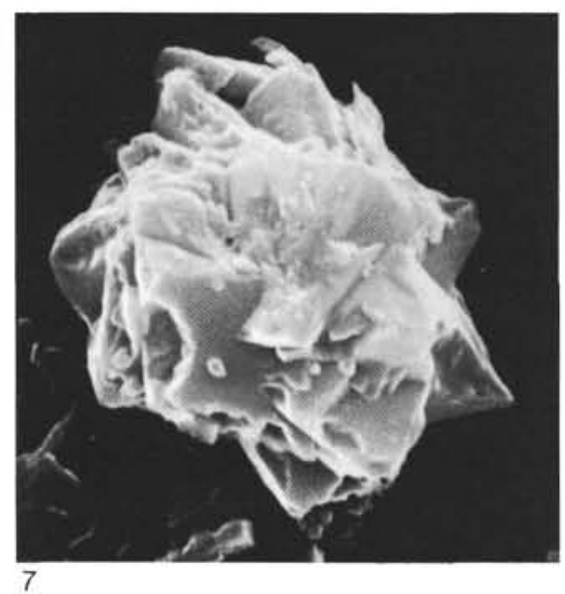

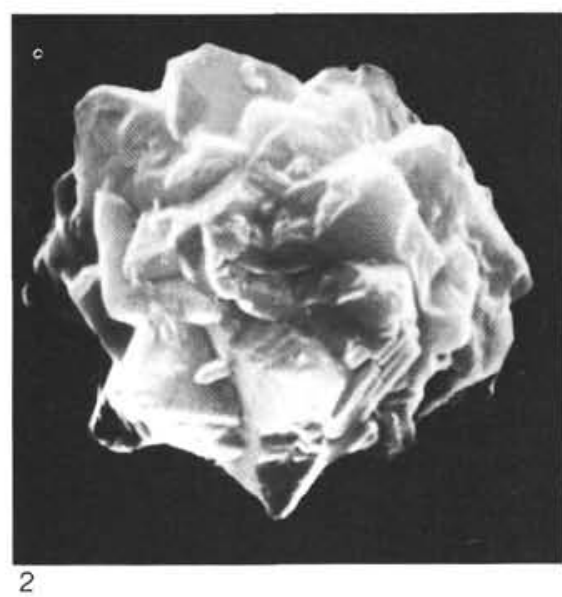
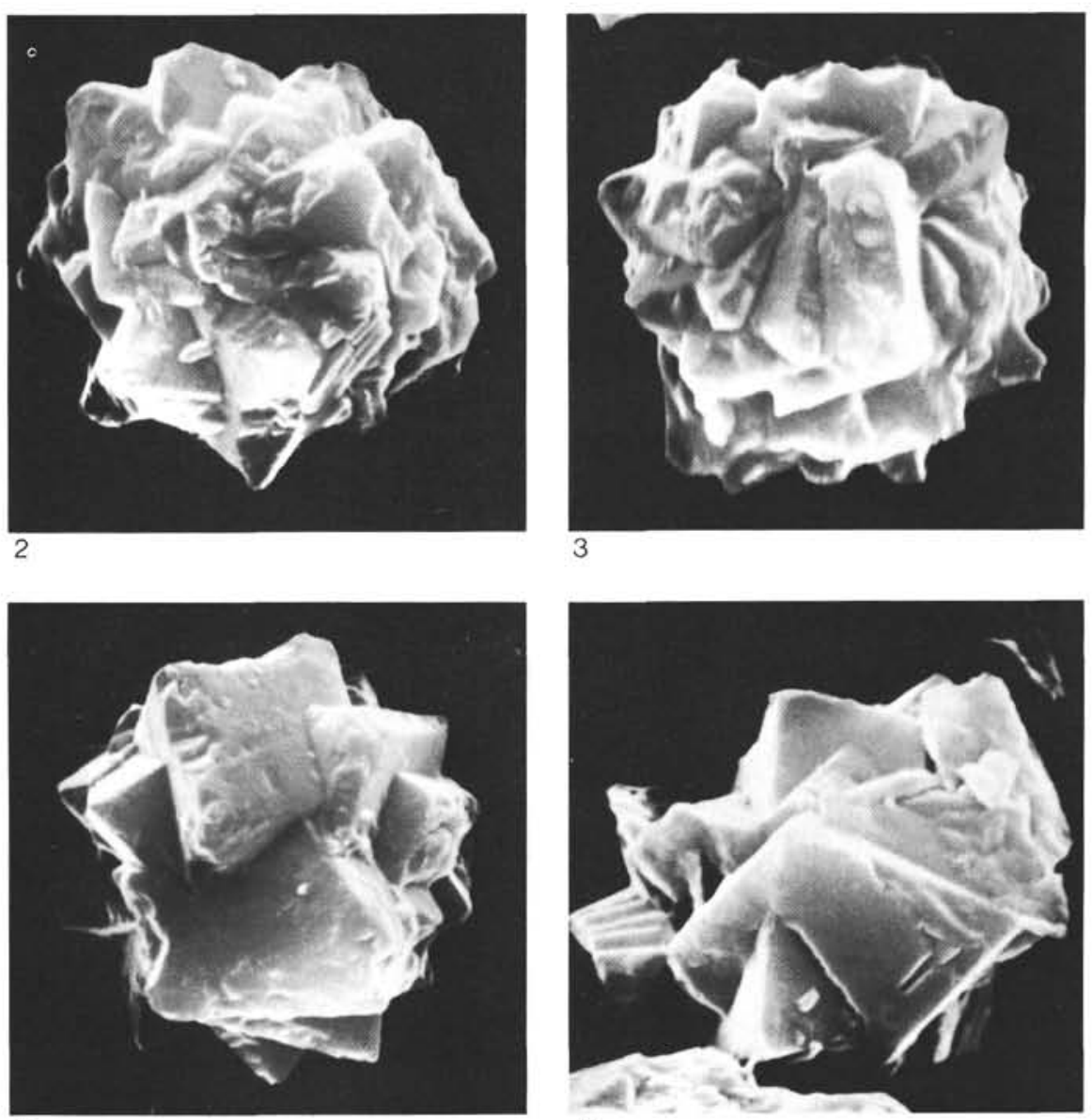

5

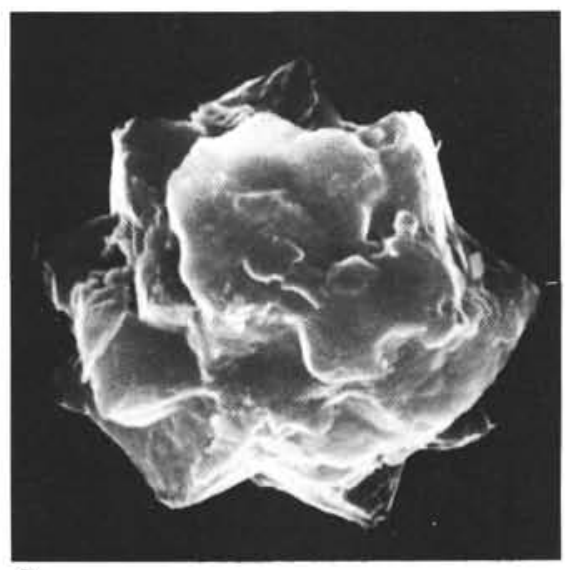

8

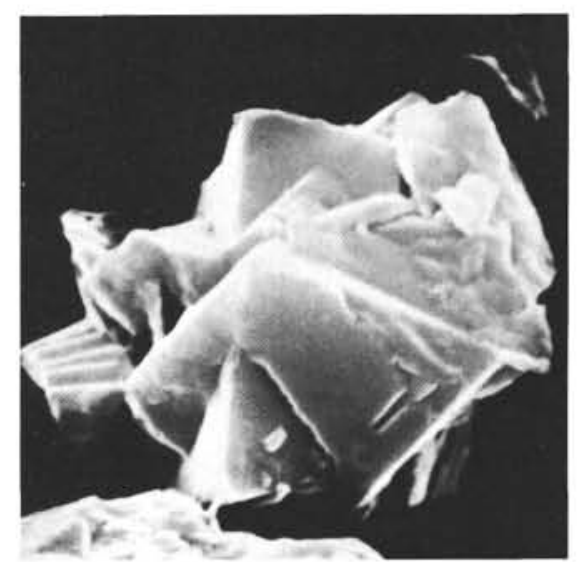

6

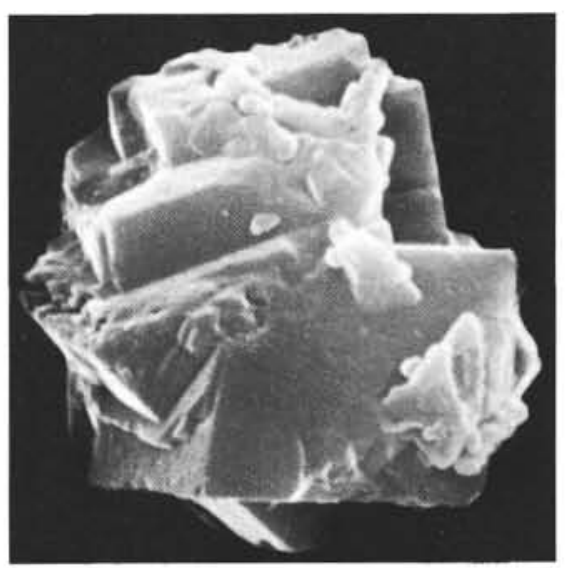

9

Plate 19. Polycyclotithaceae. 1-4. Rucinolithus terebrodentarius Applegate, Bralower, Covington, and Wise, n. sp., paratypes, Sample 603B-44$1,113 \mathrm{~cm},(1) \times 8500$; (2) $\times 8500$; (3) $\times 8000$; (4) $\times 8000$. 5-9. Genus et sp. indet., (5-7) Sample $603 \mathrm{~B}-44-1,113 \mathrm{~cm},(5, \times 9000 ; 6, \times 10,000 ; 7$, $\times 7500) ;(8) \times 7500$, Sample 603B-55-1, $100 \mathrm{~cm} ;(9) \times 9500$, Sample 603B-79-3, $134 \mathrm{~cm}$. 


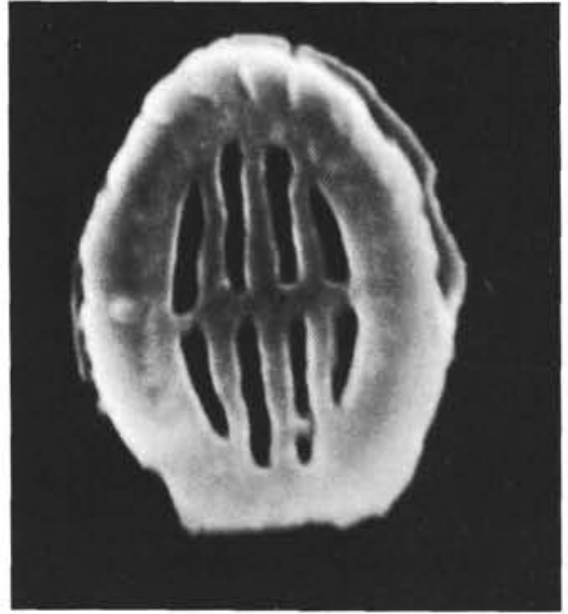

1

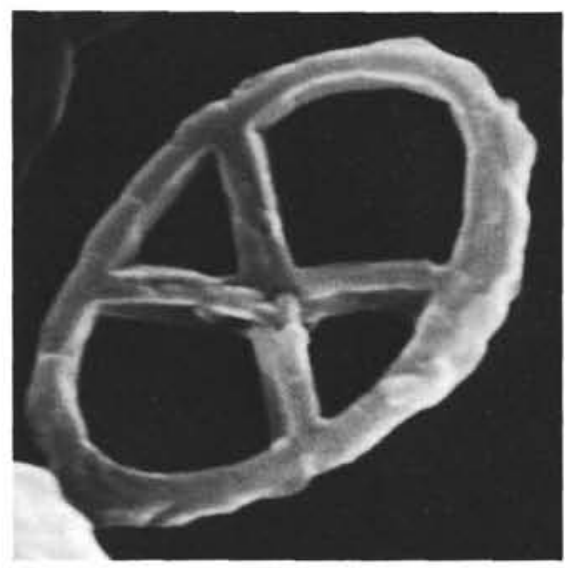

4

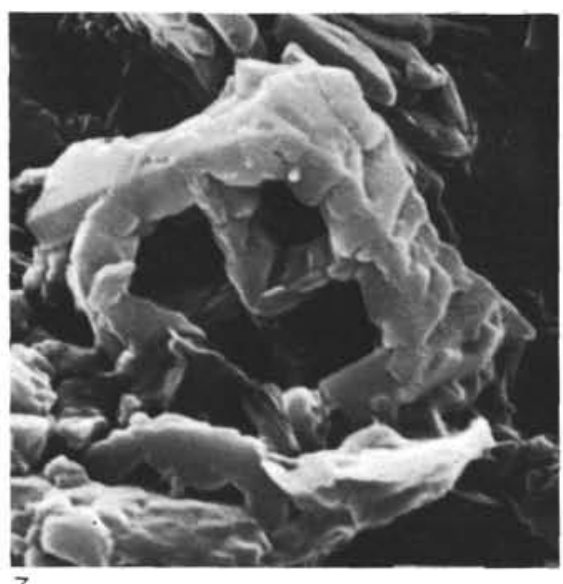
7

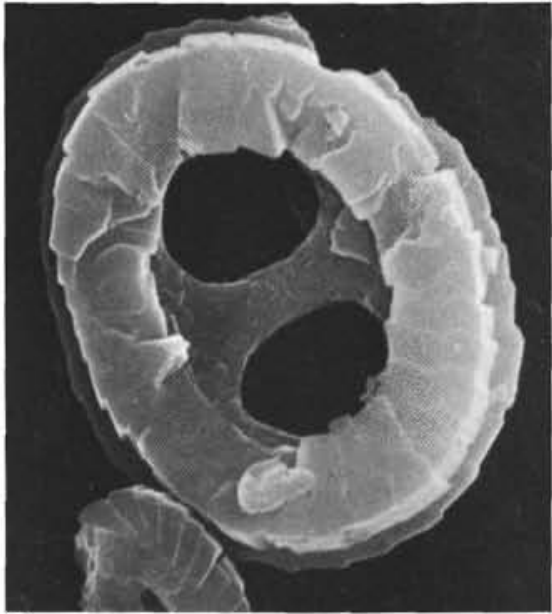

2
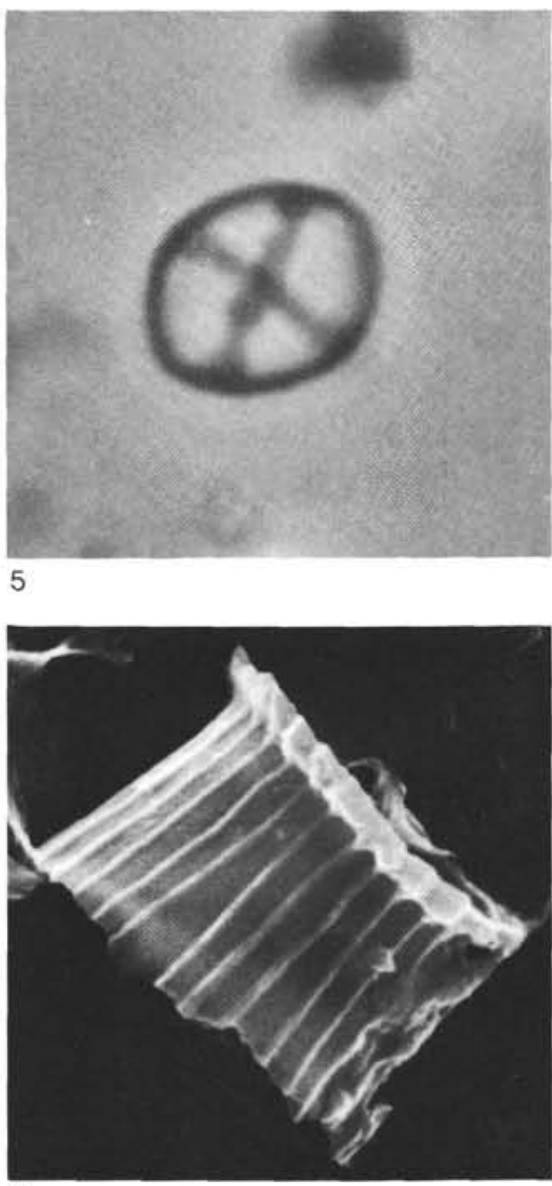

8

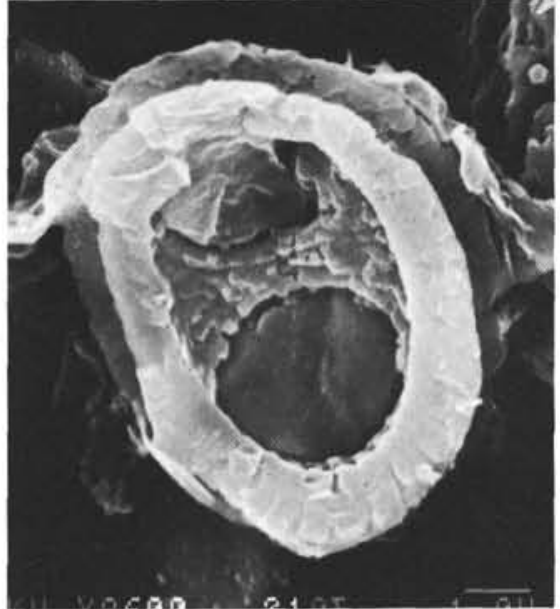

3

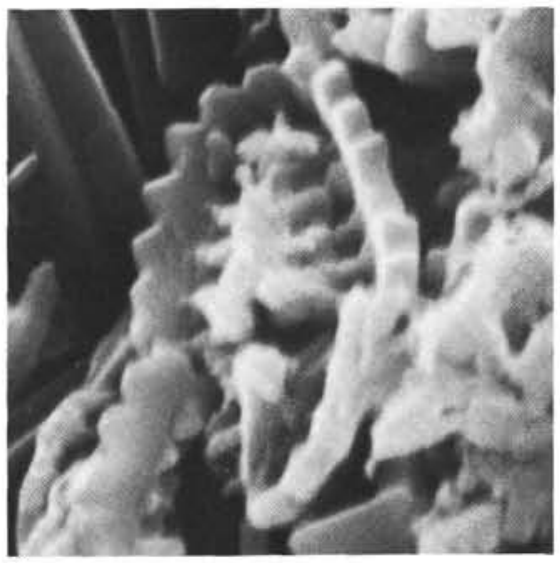

6

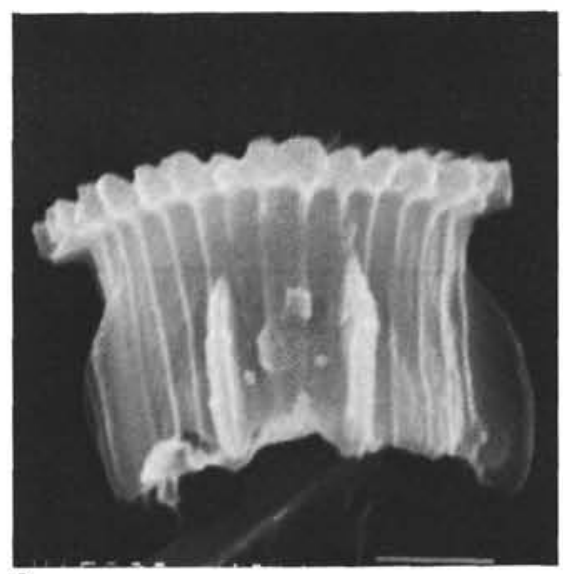

9

Plate 20. Sollasitaceae, Speetoniaceae, and Stephanolithiaceae. 1. Sollasites horticus (Stradner et al.) Black, P, $\times 1400$, Sample 603B-57-1, 34 $\mathrm{cm}$. 2, 3. Speetonia colligata Black, (2) $\mathrm{P}, \times 5500$, Sample 603B-76-3, $134 \mathrm{~cm}$; (3) $\mathrm{P}, \times 6500$, Sample $603 \mathrm{~B}-80$, CC. 4. Corollithion acutum Thierstein, $\times 16,500$, Sample 603B-44-1, $113 \mathrm{~cm}$. 5. Corollithion sp. cf. C. achylosum (Stover) Thierstein, Ph, $\times 10,000$, Sample 603B-46-2, $142 \mathrm{~cm}$. 6. Corollithion sp., $\times 15,000$, Sample 603B-48-1, $100 \mathrm{~cm}$. 7. Diadorhombus rectus Worsley, $\times 9500$, Sample $603 \mathrm{~B}-76-3,27 \mathrm{~cm} . \quad 8$, 9. Stephanolithion laffittei Noël, Sample 603B-48-1, $100 \mathrm{~cm},(8) \mathrm{L}, \times 8500$; $(9) \mathrm{L}, \times 10,500$. 

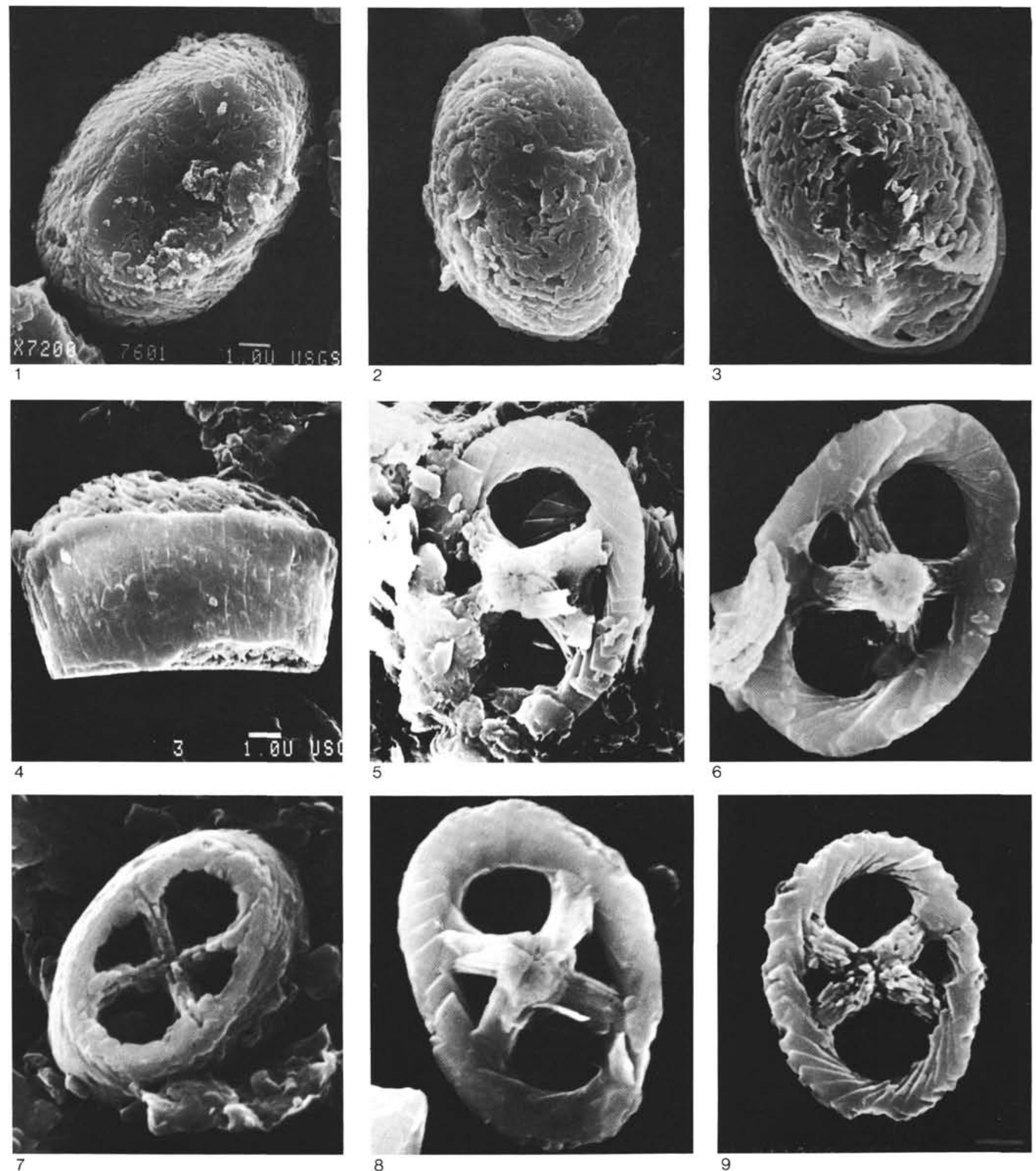

Plate 21. Crepidolithaceae and Zygodiscaceae. 1-4. Calcicalathina oblongata (Worsley) Thierstein, (1) $\mathrm{P}, \times 5500$, Sample $603 \mathrm{~B}-76-1,136 \mathrm{~cm} ;(2-$ 4) Sample 603B-57-2, $131 \mathrm{~cm},(2, \mathrm{D}, \times 4000,3, \mathrm{D}, \times 5000 ; 4, \mathrm{~L}, \times 5800)$. 5-9. Chiastozygus sp. cf. C. litterarius (Gorka) Manivit, (5-8) Sample 603B-44-1, $113 \mathrm{~cm},(5, \mathrm{D}, \times 6500 ; 6, \mathrm{D}, \times 9500 ; 7, \mathrm{P}, \times 12,000 ; 8, \mathrm{D}, \times 9000):(9) \mathrm{D}, \times 8000$, Sample $603 \mathrm{~B}-55-1,100 \mathrm{~cm}$. 

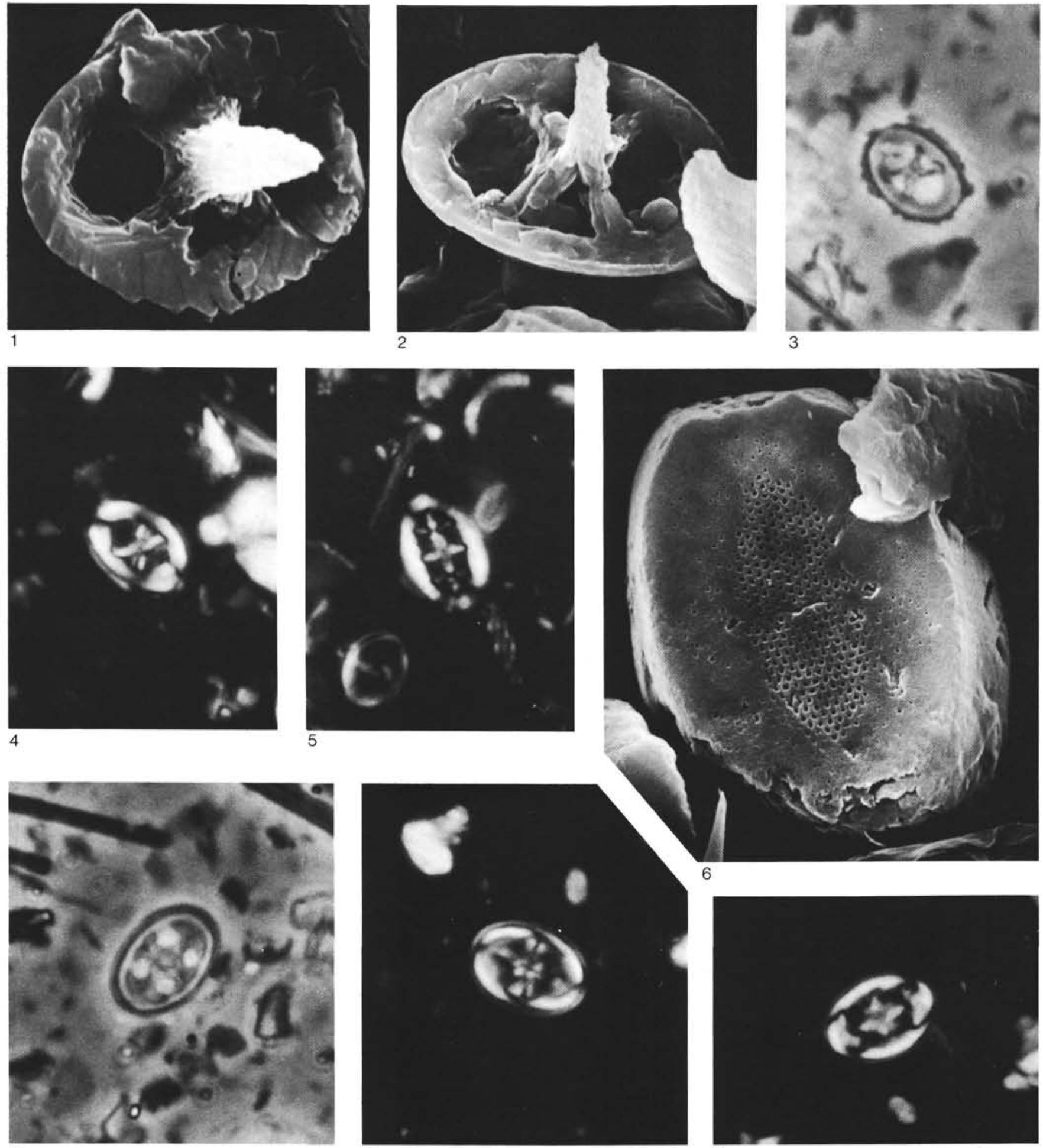

Plate 22. Zygodiscaceae, incertae sedis, Podorhabdaceae, and Eiffellithaceae?. 1. Chiastozygus sp., D, $\times 9000$, Sample $603 \mathrm{~B}-55-1,100 \mathrm{~cm} . \quad 2-4$. Tegumentum stradneri Thierstein, (2) D, $\times 10,000$, Sample 603B-44-1, $113 \mathrm{~cm} ;(3,4) \times 3250$, Sample 603B-49-3, 136 cm (3, Ph; 4, Pol). 5. Retecapsa sp., Pol, $\times 3500$, Sample 603B-55,CC. 6. Genus et species indet. 1, P, $\times 7000$, Sample 603B-60-1, 109 cm. 7-9. ?Eiffellithus sp. 2, $\times 3500$, Sample 603B-53,CC, (7) $\mathrm{Ph}$; (8) Pol; (9) Pol, rotated $45^{\circ}$. 

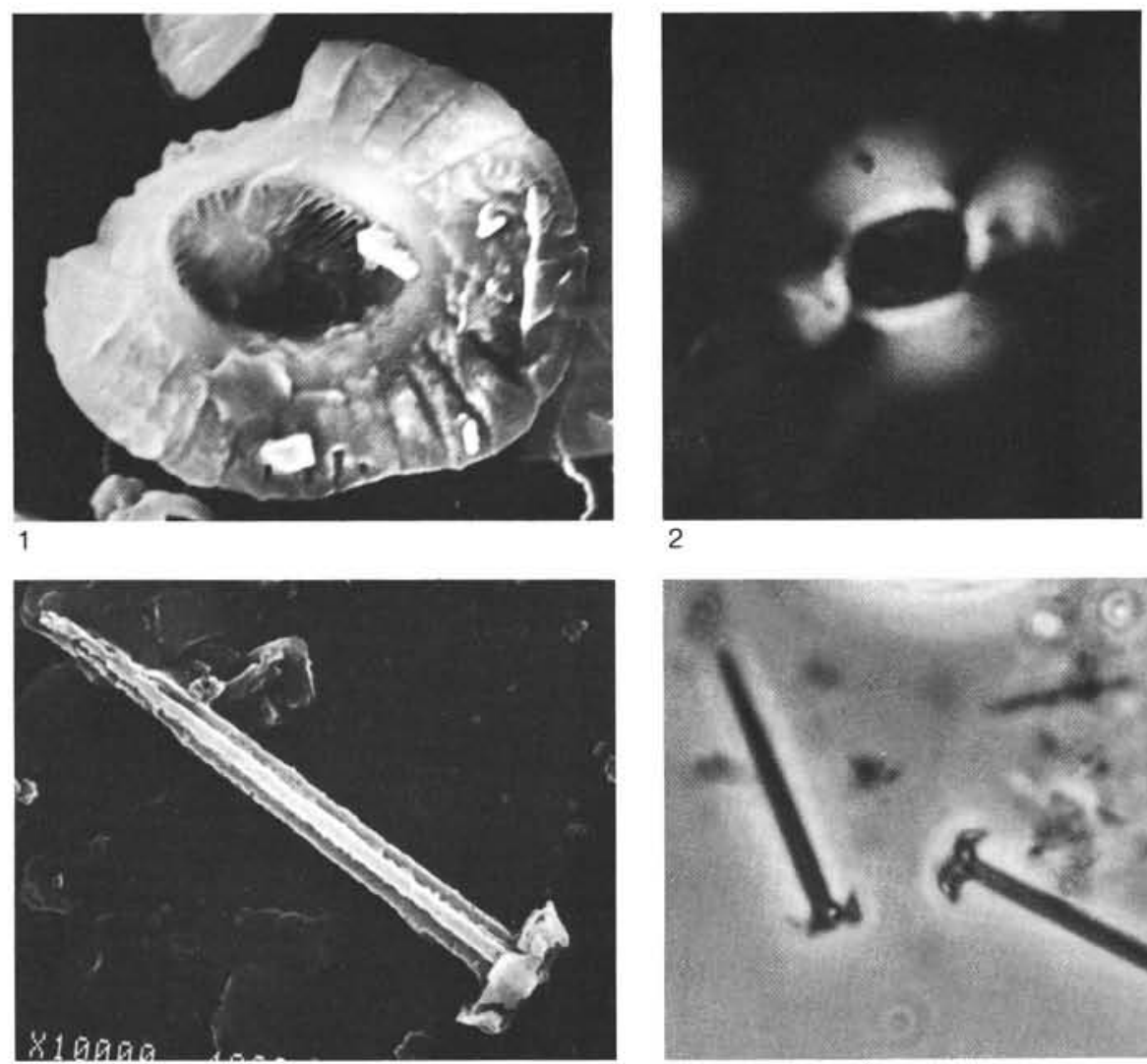

2

3

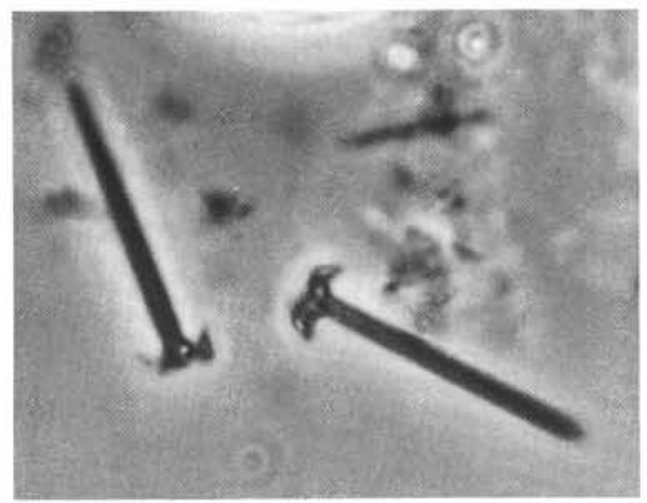

4

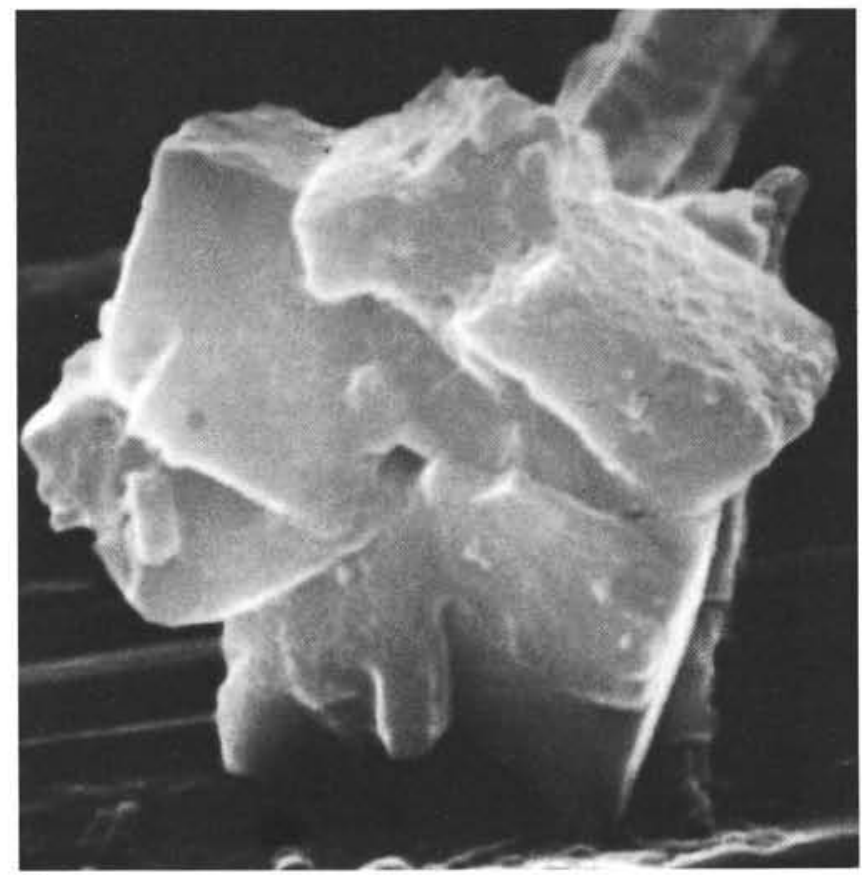

6
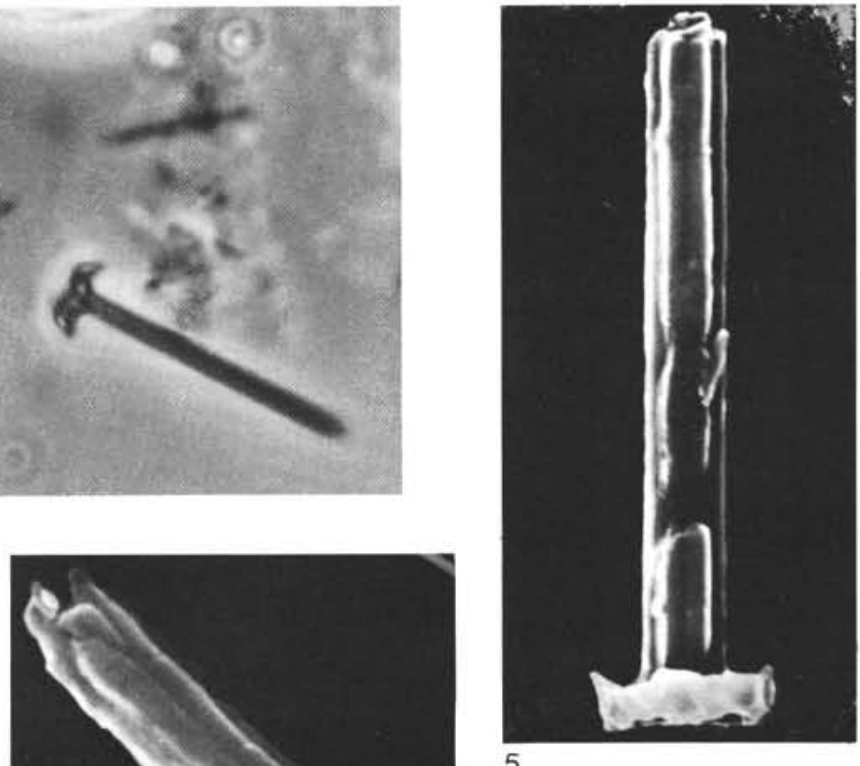

5

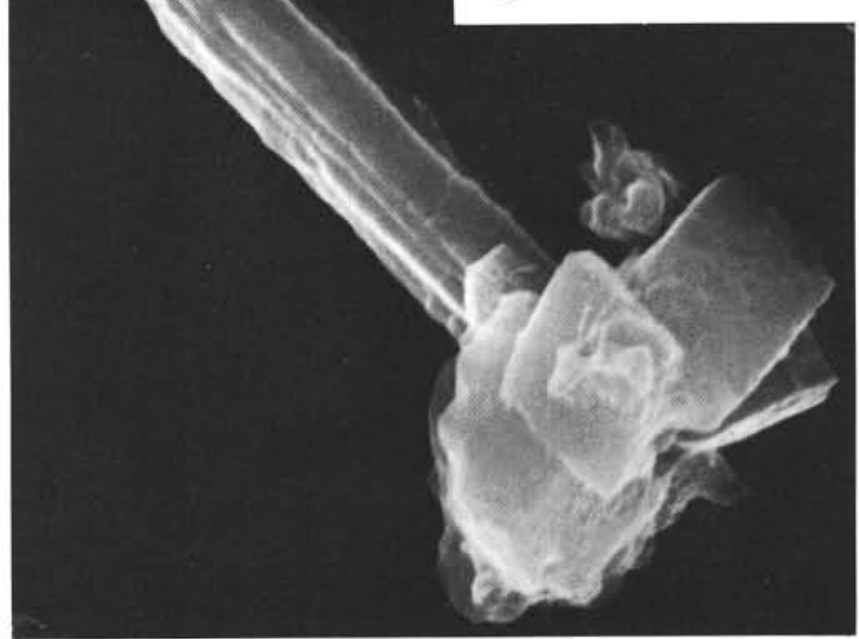

7

Plate 23. Podorhabdaceae and incertae sedis. 1, 2. Pickelhaube furtiva (Roth) Applegate, Covington, and Wise, n. gen., emend., n. comb. (1) P, $\times 6500$, Sample 603B-44-1, $113 \mathrm{~cm}$; (2) Pol, $\times 3200$, Sample 603B-53,CC. 3-5. "Rhabdolekiskus" parallelus Wind and Cepek, (3) $\times 8000$, Sample 603B-48-1, $100 \mathrm{~cm} ;(4,5)$ Sample 603B-44-1, $113 \mathrm{~cm}(4, \times 3000, \mathrm{Ph} ; 5, \times 12,000 . \quad 6,7$. Genus et species indet. 2, (7) D, $\times 18,000 ;(8) \mathrm{L}$, $\times 13,000$. 